\title{
4. Theorienbildung, konzeptionelle Anforderungen und Empirie
}

Schon 1988, nach der ersten Welle von String-Enthusiasmus unter den theoretischen Physikern, die mit der Entwicklung konsistenter, anomaliefreier perturbativer Stringtheorien einherging und im Nachhinein als "Erste Superstring-Revolution" bezeichnet werden sollte, schrieb der Wissenschaftsphilosoph Robert Weingard in einem Artikel über den Stringansatz:

"[...] there is, in a sense, no theory for the philosopher to analyse." (Weingard (1989) 138)

An den Voraussetzungen für Weingards Einschätzung hat sich bis heute nur sehr wenig geändert. Der Stringansatz ist zwar der am weitesten ausformulierte Anwärter auf den Status einer Theorie der Quantengravitation. Aber er ist, ebenso wie sein inzwischen hinzugekommener Konkurrent, die Loop Quantum Gravity, keine ausformulierte physikalische Theorie, sondern bestenfalls eine in mancher Hinsicht unübersichtliche Sammlung von physikalischen Denkansätzen und mathematischen Prozeduren, die vielleicht irgendwann einmal zu einer physikalischen Theorie führen könnten oder eben auch nicht.

Für eine vollentwickelte physikalische Theorien fehlen dem Stringansatz bisher vor allem eine eindeutige und einheitliche nomologische Basis und die Einsicht in die Prinzipien, die dieser Nomologie zugrundeliegen könnten. Und es ist immer noch nicht klar, ob dieser Mangel nicht vielleicht doch darauf zurückzuführen sein könnte, dass es sich beim Stringansatz möglicherweise um eine physikalische Sackgasse handelt, deren bisherige konzeptionelle Erfolge, für die es immer noch keine einzige empirische Stützung gibt, ein Artefakt einer bestimmten modelltheoretischen Vorgehensweise darstellen.

Insofern kann man sich berechtigterweise fragen, ob es sinnvoll ist, sich mit einem solchen unabgeschlossenen Konstrukt wissenschaftstheoretisch auseinanderzusetzen, oder ob man damit nicht besser warten sollte, bis sich eine wirkliche, physikalische und empirisch verwurzelte Theorie der 
Quantengravitation konstituiert hat. Nicht nur, dass es für den Stringansatz - ebenso wie für seine möglichen Konkurrenten im Bereich der Quantengravitation - bisher nicht die geringsten quantitativen Vorhersagen gibt, die einer empirischen Überprüfung ausgesetzt werden könnten. ${ }^{157}$ Hinzu kommt, dass es für den Bereich der Quantengravitation, wie noch zu erörtern sein wird, bisher nicht die geringsten empirischen Indizien und Erfordernisse gibt, die eine Theorienbildung motivieren könnten. ${ }^{158}$ Es gibt nicht ein einziges empirisches Faktum, welches nicht mit den bestehenden Theorien wie dem Standardmodell der Quantenfeldtheorien und der Allgemeinen Relativitätstheorie in Einklang stände und insofern eine Theorie der Quantengravitation erforderlich machen würde. Alle Motivationen für eine Theorie der Quantengravitation bewegen sich bisher im Bereich konzeptioneller oder metaphysischer Ideen; sie wurzeln letztendlich alle im Programm konzeptioneller bzw. nomologischer Vereinheitlichung. ${ }^{159}$

Jeremy Butterfield und Christopher Isham beginnen konsequenterweise ihren Überblick über die Ansätze zu einer Quantengravitationstheorie und die diesen zugrundeliegenden Raumzeitkonzeptionen - erschienen in dem von Craig Callender und Nick Huggett 2001 herausgegebenen Sammelband Physics meets Philosophy at the Planck Scale, der sich mit den verschiedenen Facetten des Problems der Quantengravitation auseinandersetzt und in dem auch der eingangs zitierte Artikel von Weingard wiederabgedruckt wurde - mit den Worten:

"No data, no theory, no philosophy?" (Butterfield / Isham (2001) 36)

Aber diese vor allem rhetorisch gemeinten Einwände gegen eine wissenschaftsphilosophische Beschäftigung mit unfertigen theoretischen Konstrukten halten Butterfield und Isham nicht von einer solchen metatheoretischen Auseinandersetzung mit den Theorieansätzen zur Quantengravitation $a b$, ebensowenig wie Weingards oben zitierter Einwand diesen davon abgehalten hat, sich mit dem Stringansatz wissenschaftstheoretisch auseinanderzusetzen. Zugegebenermassen gibt es aber bisher nicht allzuviele weitere Beispiele einer wissenschaftstheoretischen Auseinandersetzung mit dem Stringansatz. Die meisten Wissenschaftsphilosophen, die sich mit moderner Physik beschäftigen, beschränken diese Beschäftigung auf die 
Quantenmechanik und ihre Interpretationsprobleme. Darüberhinaus nimmt in den letzten Jahren die wissenschaftstheoretische Reflektion der offenen Probleme der Quantenfeldtheorien, insbesondere das ihrer ontologischen Implikationen, zumindest zu, ebenso wie die hinsichtlich der immer noch offenen Probleme in der Deutung der Allgemeinen Relativitätstheorie.

Warum sollte man sich auch mit einer unfertigen Theorie beschäftigen, wenn es noch genug philosophische Probleme für die als abgeschlossen geltenden physikalischen Theorien zu bewältigen gibt? - Es sind zwei Faktoren, die trotz dieser Einwände, eine wissenschaftstheoretische Beschäftigung mit dem Stringansatz nahelegen könnten:

1. Der Stringansatz versucht als Ansatz zu einer Theorie der Quantengravitation nicht zuletzt die Probleme zu beheben, die zur konzeptionellen Unverträglichkeit unserer zur Zeit fundamentalsten physikalischen Theorien führen - der Quantenmechanik bzw. der Quantenfeldtheorien auf der einen Seite und der Allgemeinen Relativitätstheorie auf der anderen. Die Problemlagen dieser Theorien, die schon einige Zeit Gegenstand wissenschaftsphilosophischer Bemühungen sind, könnten im Rahmen eines solchen Ansatzes aus einer neuen, übergeordneten Perspektive beleuchtet werden, die sich auch für die schon bestehenden wissenschaftsphilosophischen Forschungsprogramme als relevant erweisen könnte. Möglicherweise sind bestimmte Fragen hinsichtlich unserer zur Zeit fundamentalsten physikalischen Theorien überhaupt erst im Rahmen einer Theorie der Quantengravitation adäquat behandelbar und vielleicht sogar beantwortbar.

$\mathrm{Ob}$ die durch dieses erste Argument gegebene Motivation für eine wissenschaftstheoretische Beschäftigung mit dem Stringansatz wirklich schon hinreichend sein wird, ist immerhin fraglich. Dazu müssten vermutlich wesentlich konkretere Vorstellungen darüber existieren, welche wissenschaftstheoretischen Probleme hinsichtlich der Quantenmechanik, der Quantenfeldtheorien und der Allgemeinen Relativitätstheorie erst im Rahmen einer wissenschaftstheoretischen Auseinandersetzung mit einer Theorie der Quantengravitation in angemessener Weise behandelt werden können und warum sich dies so verhält. Hierzu gibt es aber bestenfalls recht unklare Spekulationen. - Eine wesentlich bessere Motivation für eine wissenschaftstheoretische Auseinandersetzung mit dem Stringansatz liefert vermutlich das zweite Argument: 
2. Der Stringansatz existiert seit über dreissig Jahren und ist seit etwa zwanzig Jahren ein aufstrebendes Forschungsprogramm, an dem mittlerweile sehr viele Physiker arbeiten und das von noch viel mehr Physikern ernst genommen wird. Dies ist umso erstaunlicher als es während des gesamten Bestehens des Stringansatzes nie irgendwelche empirisch überprüfbaren Vorhersagen gegeben hat und insofern eine empirische Einbettung nicht stattgefunden hat. Was hält ein in seiner Selbstzuschreibung empirisch-wissenschaftliches Forschungsprogramm ohne empirische Ankopplung so lange am Leben? Handelt es sich vielleicht gar nicht um einen empirisch-wissenschaftlichen Ansatz? Hat die Physik mit ihrem Vereinheitlichungsprogramm unter strikter Verfolgung der Strategien, die ihr schon seit Jahrhunderten zugrundelagen, mit dem Stringansatz vielleicht den Bereich der empirischen Wissenschaften verlassen, um sich einer mathematisch inspirierten Naturmetaphysik zu verschreiben? - Eine Antwort auf diese Fragen wird ganz sicher nicht von der Physik selbst zu erwarten sein, denn diese verfügt überhaupt nicht über das dafür erforderliche Instrumentarium. Es handelt sich vielmehr um metatheoretische, originär wissenschaftsphilosophische Fragestellungen, deren Beantwortung von einer Philosophie der Physik zu leisten sein wird. Und es gibt sicherlich keinen guten Grund, die wissenschaftsphilosophische Auseinandersetzung mit diesen Fragen noch um einige Jahrzehnte aufzuschieben, in der Hoffnung, dass es dann eine vollständige, empirisch gestützte Theorie geben wird, oder sich das Problem von selbst erledigt haben wird. Denn diese Hoffnung muss sich nicht unbedingt erfüllen. Und dies könnte nicht zuletzt gerade an den Problemen liegen, die gerade im Rahmen einer wissenschaftsphilosophischen Auseinandersetzung mit dem Stringansatz zu klären gewesen wären.

$\mathrm{Zu}$ beachten ist allerdings, dass eine wissenschaftstheoretische Auseinandersetzung mit einer in grundlegender Weise unfertigen und empirisch unbestätigten Theorie bzw. einem noch vollständig unabgeschlossenen theoretischen Forschungsfeld gegenüber den traditionellen Vorgehensweisen der Wissenschaftstheorie in mancher Hinsicht offener und flexibler vorgehen muss:

"'Quantum gravity' primarily refers to an area of research, rather than a particular theory of quantum gravity. Several approaches exist, 
none of them entirely successful to date. Thus the philosopher's task, if indeed she has one, is different from what it is when dealing with a more-or-less settled body of theory such as classical Newtonian mechanics, general relativity, or quantum mechanics. In such cases, one typically proceeds by assuming the validity of the theory or theoretical framework and drawing the ontological and perhaps epistemological consequences of the theory, trying to understand what it is that the theory is telling us about the nature of space, time, matter, causation, and so on. Theories of quantum gravity, on the other hand, are bedeviled by a host of technical and conceptual problems, questions, and issues which make them unsuited to this approach. However, philosophers who have a taste for a broader and more open-ended form of inquiry will find much to think about." (Weinstein (2005) 2)

Auch wenn neuere Entwicklungen die heutigen physikalischen Einschätzungen entscheidend verändern werden, so sollte die Wissenschaftsphilosophie, kompliziert wie die Zusammenhänge heute schon sind, hier nicht den Anschluss verlieren, sondern rechtzeitig mit ihren Bemühungen beginnen, die schon erfolgten Entwicklungen aufzuarbeiten und gleichzeitig das aktuelle Geschehen und seine jeweiligen Zukunftsperspektiven im Auge zu behalten.

Am Beginn steht dabei notwendigerweise ein Blick auf das, was den heutigen Stringansatz hinsichtlich seiner Randbedingungen, Ansprüche, Leistungen und Probleme auszeichnet, ebenso wie auf die Entwicklungen, die zum heutigen Stand der Dinge geführt haben - und die es verstehbar werden lassen sollten, wie ein solcher Ansatz ohne empirische Ankopplung überhaupt so lange überleben konnte. Dazu ist es nun erst einmal sinnvoll, die "Theorienbildung" hinsichtlich ihrer physikalischen, modelltheoretischen, konzeptionellen und philosophischen Anforderungen sowie in Bezug auf ihre empirischen Randbedingungen genauer zu durchleuchten. 


\subsection{Die Entwicklung der Stringtheorien}

Sogar führende Stringtheoretiker verweisen auf das Bizarre an der Entwicklung ihres Ansatzes. Schon 1985 schrieb John Schwarz in der Einleitung zu seiner Anthologie Superstrings - The First 15 Years of Superstring Theory:

"Superstring theory has a bizarre history." (Schwarz (1985) v)

Bis heute hat sich nichts daran geändert. Und auch heute noch hängt die Frage nach den Determinanten dieser bizarren Entwicklung eng mit der Frage zusammen, was den Stringansatz inzwischen über dreissig Jahre am Leben erhalten hat bzw. wieso der Stringansatz überhaupt für die Physik von Interesse ist?

\section{Die Anfänge in der Hadronenphysik}

Der Stringansatz begann mit einem relativ exotischen mathematischen $\mathrm{Zu}-$ fallsfund im Kontext der Hadronenphysik: 1968 arbeitete Gabriele Veneziano an einer Theorie, die das Verhalten der starken Wechselwirkung erklären sollte. Dabei machte er die gleichermassen erstaunliche wie zufällige Entdeckung, dass die Streumatrix von Hadronenkollisionen sich mit der Eulerschen Betafunktion beschreiben liess.

"Thumbing through old mathematics books, they stumbled by chance on the Beta function, written down in the last century by mathematician Leonhard Euler. To their amazement, they discovered that the Beta function satisfied almost all the stringent requirements of the scattering matrix describing particle interactions. Never in the history of physics has an important scientific discovery been made in quite this random fashion." (Kaku (1999) vii)

Venezianos auf der Grundlage dieser Entdeckung entwickelter Ansatz zur Beschreibung von Hadronenkollisionen sollte bald unter dem Namen 
Dual-Theorie bzw. Dual Resonance Model formieren. Es war allerdings physikalisch vollkommen unklar, wieso die Eulersche Betafunktion der Streumatrix für Hadronenkollisionen entsprach. Erst einmal handelte es sich um eine mathematische Formel ohne eine wirkliche physikalische Idee, die ihre Anwendbarkeit in der Hadronenphysik erklärt hätte. 1970 fanden dann Leonard Susskind, Holger Nielsen, Yoichiro Nambu und T. Goto heraus, dass das mathematische Instrumentarium der Dual-Theorie als quantisierte Dynamik von oszillierenden, eindimensional ausgedehnten Entitäten gedeutet werden kann. Diese eindimensional ausgedehnten Entitäten nennt man heute Strings. ${ }^{160}$

"Nambu and Goto realized that lurking behind these scattering amplitudes was a classical relativistic string. In one sweep, they revolutionized the entire theory by revealing the unifying, classical picture behind the theory." (Kaku (1999) 15)

Die Dual-Theorie entsprach damit formal der Erweiterung der perturbativen Quantenfeldtheorie von Punktentitäten zu eindimensionalen Strings. Und es gab schon bald danach zwei verschiedene mathematische Modelle, die für das quantenmechanische Verhalten solcher Strings standen: das Veneziano-Modell, das die Dynamik von offenen Strings beschrieb, und das Shapiro-Virasoro-Modell, dem geschlossene Strings zugrundelagen. Schon damals zeigte sich, dass sowohl das Veneziano- als auch das Shapiro-Virasoro-Modell nur für den Fall von 26 Dimensionen konsistent formulierbar waren. Die Bedeutung dieser Tatsache blieb jedoch erst einmal vollkommen im Unklaren, was die Popularität der Dual-Theorie in der Hadronenphysik nicht gerade steigerte.

\section{Supersymmetrie und fermionische Zustände}

Schon um 1970 wurde deutlich: Will man das durch die starke Wechselwirkung bestimmte Verhalten von Hadronen, also etwa den Austausch von bosonischen Mesonen zwischen fermionischen Nukleonen, im Rahmen der Dual-Theorie adäquat beschreiben, so benötigt man einen Ansatz, der so-

\footnotetext{
160 Man ging in der Dual-Theorie von einer Stringausdehnung in der der Hadronenphysik angemessenen Grössenordnung von $10^{-15} \mathrm{~m}$ aus.
} 
wohl bosonische als auch fermionische Zustände für den String zulässt. Aber sowohl das Veneziano- als auch das Shapiro-Virasoro-Modell beschrieben nur Bosonen, keine Fermionen. In beiden Ansätzen ergaben sich für die Strings ausschliesslich bosonische Oszillationszustände. Und der Theorieansatz war entsprechend auch nicht in der Lage, die Chiralität der Fermionen zu berücksichtigen, also die Tatsache, dass sich (hinsichtlich der Spinorientierung) rechts- und linkshändige Fermionen unterschiedlich verhalten. (Es ist die Chiralität der Fermionen, die nicht zuletzt zur Paritätsverletzung bei der schwachen Wechselwirkung führt.) Zudem sagten die rein bosonischen Stringtheorien Spin-0-Teilchen mit negativem Massequadrat vorher: Tachyonen. Diese führen, wie man wusste, zur Instabilität des Vakuums und der Raumzeit, waren also für einen ernstzunehmenden Theorieansatz nicht hinnehmbar.

1971 erweiterten Pierre Ramond, André Neveu und John Schwarz die Dual-Theorie schliesslich dahingehend, dass sich auch fermionische $\mathrm{Zu}$ stände für die Strings ergaben. ${ }^{161}$ Um dies zu erreichen, definierten sie für jeden Punkt des Weltblattes der Stringentwicklung einen Majorana-WeylSpinor. J.L. Gervais und B. Sakita zeigten noch im selben Jahr, dass die im Ansatz von Ramond, Neveu und Schwarz für die Stringdynamik gewählte Wirkungsfunktion auf dem Weltblatt des String eine interessante, neuartige Invarianz aufweist, die später als Supersymmetrie bezeichnet werden sollte. ${ }^{162}$ Die Supersymmetrie ist eine Invarianz der Wirkungsfunktion gegenüber der Vertauschung von bosonischen und fermionischen Zuständen. Für jeden bosonischen Zustand gibt es einen entsprechenden fermionischen Zustand und umgekehrt. Es wurde bald klar, dass eine Stringtheorie, die Fermionen einbezieht, notwendigerweise genau diese Eigenschaft aufweisen muss. In der alten Neveu-Schwarz-Ramondschen Dual-Theorie bleibt die Supersymmetrie, die - wie man später herausfand - eigentlich für die gesamte Raumzeit, auf der sich die Stringdynamik abspielt, gelten muss, jedoch verdeckt. Eine manifeste Invarianz hinsichtlich des Austauschs von bosonischen und fermionischen Zuständen liegt bei diesem Ansatz erst einmal nur für das Weltblatt der Stringdynamik vor; und die Entdeckung dieser Weltblatt-Supersymmetrie durch Gervais und Sakita wurde nur von einigen Insidern beachtet, aber nicht mit der Aufmerksamkeit bedacht, die der Supersymmetrie aufgrund ihrer Bedeutung für den Stringansatz später

Siehe Ramond (1971) und Neveu / Schwarz (1971).

162 Siehe Gervais / Sakita (1971). 
zukommen sollte. ${ }^{163} 164$ Denn es gab erst einmal dringlichere Probleme: Es zeigte sich nämlich sehr schnell, dass die von Ramond, Neveu und Schwarz entwickelte supersymmetrische Variante der Dual-Theorie - das was heute als Superstringtheorie bezeichnet wird - nur für zehn Raumzeitdimensionen konsistent formuliert werden kann. Die Bedeutung dieser Tatsache blieb - wie schon bei den 26 Dimensionen der bosonischen Stringtheorien, an denen zu dieser Zeit immer noch gearbeitet wurde vollkommen im Unklaren. Was sollte man mit zehn (oder 26) Dimensionen in der Hadronenphysik anfangen? Konsequenterweise gab es nach 1973, nach dem empirischen Erfolg des Quark-Modells und dem Siegeszug der Quantenchromodynamik, die inzwischen eindeutige empirische Indizien für sich ins Feld führen konnte, erst einmal nur noch wenig weiteres Interesse am Stringansatz.

"[...] the rapid development of $Q C D$ as a theory of hadronic interactions seemingly put the last nail in the coffin of the superstring." (Kaku (1999) 16)

\section{Die entscheidende Entdeckung}

Wäre nach dem Siegeszug der Quantenchromodynamik und des QuarkModells nichts entscheidend und überraschend Neues mehr hinsichtlich des Stringansatzes passiert, würden heute sicherlich nur noch ein paar ältere Männer und ein paar Wissenschaftshistoriker auf Profilsuche in den

\footnotetext{
163 "Supersymmetry, as an invariance of an action, was first discovered in the string theory. Gervais and Sakita showed that an extension of the usual bosonic action possessed a symmetry that converted bosons into fermions. Unfortunately, it languished for many years because the supersymmetry of the early string model was a two-dimensional supersymmetry on the world sheet. It wasn't until relatively recently that it was finally proved that the string model possessed both twodimensional and 10-dimensional space-time supersymmetry." (Kaku (1999) 103)

164 Aber immerhin war es der Stringansatz, der auf den Nebenpfaden modelltheoretischer Bemühungen zu einer systematischen Beschäftigung mit der Supersymmetrie führte: So entwickelten Julius Wess und Bruno Zumino zwischen 1971 und 1974, angeregt durch deren vorauseilende physikalische Implementierung in der Dual-Theorie, eine angemessene mathematische Grundlage für die Supersymmetrie. Siehe Wess / Zumino (1974) und Zumino (1979).
} 
Nebengleisen der modernen Physik von Zeit zu Zeit vom Stringansatz reden (oder schreiben). Ihn hätte etwa das gleiche Schicksal ereilt wie den S-Matrix- oder den Bootstrap-Ansatz. Nur die grosse Überraschung, zu der es $1974 \mathrm{kam}$, konnte dies verhindern. Und es ist ausschliesslich diese $\mathrm{Zu}$ fallsentdeckung, die dazu geführt hat, dass der Stringansatz heute noch existiert. Aber, ganz im Gegensatz zu dem, was man heute vielleicht annehmen könnte, wurde diese für den Stringansatz entscheidende Entdeckung damals nur von sehr wenigen Physikern überhaupt wahrgenommen, um erst zehn Jahre später grössere Kreise zu ziehen.

Nun, um was handelt es sich bei dieser allesentscheidenden Entdeckung? Joel Scherk und John Schwarz fanden 1974 heraus, dass es für geschlossene bosonische Strings nach der Quantisierung grundsätzlich einen masselosen Spin-2-Stringzustand gibt und dass dessen Streuamplitude in der Niederenergienäherung zumindest formal den Streuamplituden für die Graviton-Graviton-Streuung entspricht. ${ }^{165}$ Schon die simple Quantisierung eines klassisch-relativistischen Strings und seiner Dynamik führt also zur Gravitation. ${ }^{166}$ Inzwischen ist klar, dass masselose Spin-2-Teilchen, die sich Lorentz-invariant verhalten, notwendigerweise gravitatives Verhalten gemäss der Allgemeinen Relativitätstheorie reproduzieren, auch wenn keine Einigkeit besteht, auf wen der Nachweis letztendlich zurückgeht. ${ }^{167}$

165 Siehe Scherk / Schwarz (1974).

166 Die Allgemeine Relativitätstheorie und ihr Äquivalenzprinzip stellen sich, wie sich hier zeigt, als Niederenergienäherung der Dynamik des String dar.

"The claim that string theory solves [Quantum Gravity] is based on two facts. First, the string perturbation expansion includes the graviton. More precisely, one of the string modes is a massless spin two, and helicity +-2 particle. Such a particle necessarily couples to the energy-momentum tensor of the rest of the fields and gives general relativity to a first approximation. Second, the perturbation expansion is consistent if the background geometry over which the theory is defined satisfies a certain consistency condition; this condition turns out to be a high energy modification of the Einstein's equation. The hope is that such a consistency condition for the perturbation expansion will emerge as a full-fledged dynamical equation from the yet-to-be-found nonperturbative theory." (Rovelli (1998) 4)

167 "Now we can use a general result that goes back to Feynman: any theory of an interacting spin two massless particle must describe gravity. So string theory must reproduce gravitational physics." (Giddings (2005) 6)

"[...] with appropriate caveats, general relativity is necessarily recovered as the low-energy-limit of any interacting theory of massless spin-2 particles propaga- 
"The only consistent interaction for massless spin two particles is that of gravity. Therefore, any string theory will contain gravity." (Aharony et al. (1999) 4)

Die Entdeckung von Scherk und Schwarz erschien im ersten Moment als etwas, was man für die intendierten Ziele des Ansatzes überhaupt nicht gebrauchen konnte: Was macht man mit Gravitonen bzw. Spin-2-TensorZuständen in der Hadronenphysik und bei der starken Wechselwirkung? Schnell wurde aber klar: So etwas taugt eigentlich nur für die Beschreibung der gravitativen Wechselwirkung. Was ebenso dafür sprach, dass der Stringansatz nichts mit der Hadronenphysik zu tun hat, sondern vielmehr die Gravitation im Rahmen eines quantenmechanischen Ansatzes zu beschreiben in der Lage sein könnte, war die Tatsache, dass die Gravitation, wie sich sehr schnell zeigen liess, nur dann die richtige (nämlich die empirisch beobachtbare) Stärke annimmt, wenn sich die Stringdynamik auf der Planck-Ebene abspielt. ${ }^{168}$ Die Planck-Ebene ist aber gerade der Bereich, für den man aufgrund der Konvergenz der Kopplungskonstanten eine vereinheitlichte Beschreibung aller Wechselwirkungen erwartet. Es war also nicht allzu abwegig zu vermuten, dass eine Theorie, die notwendigerweise Spin-2-Zustände enthält und die zudem den dafür richtigen Energiebereich betrifft, als vereinheitlichte Theorie aller Wechselwirkungen in Frage kommen könnte. Noch weniger abwegig war dies, als man feststellte, dass Theorien mit geschlossenen Strings neben den Spin-2-Zuständen noch skalare Spin-0-Zustände enthalten und Theorien mit offenen Strings zu Spin-1-Tensor-Zuständen führen. Nicht nur die Allgemeine Relativitäts-

ting on a Minkowski background, in which the energy and momentum are conserved (Boulware and Deser 1975)." (Butterfield / Isham (2001) 59)

"Weinberg (1995), in his discussion of covariant quantum gravity, showed that, in the vacuum case, one can derive the equivalence principle and general relativity from the Lorentz-invariance of the spin-2 quantum field theory of the graviton: the spin-2 theory is equivalent to general relativity and follows from the quantum theory. The upshot of this is that any theory with gravitons is a theory that can accommodate general relativity (in some appropriate limit). This analysis forms the basis of string theory's claim that it is a candidate theory of quantum gravity: since there is a string vibration mode corresponding to a massless spin-2 particle, there is an account of general relativity [...]." (Rickles (2005) 9)

168 Dies ist eine Folge davon, dass die aus der Stringdynamik resultierenden Eigenschaften der Gravitonen-Zustände abhängig sind von der Stringspannung, also ihrer Energie bzw. Masse pro Längeneinheit. 
theorie, sondern auch die Eichinvarianzen der Quantenfeldtheorien des Standardmodells würde man also unter den Niederenergienäherungen der Stringdynamik erwarten können.

Es gab jedoch allen Grund, die Hoffnungen nicht auf die alten bosonischen Stringtheorien, für die die Entdeckung der Gravitonenzustände von Scherk und Schwarz ursprünglich gemacht wurde, zu setzen, sondern auf den supersymmetrischen Stringansatz, die Superstringtheorie also, in deren Kontext immerhin einige der grundlegenden Probleme der alten bosonischen Stringtheorien lösbar erschienen. Glücklicherweise liess sich sehr schnell aufzeigen, dass die ursprünglich für die bosonischen Stringtheorien nachgewiesene Existenz von Gravitonenzuständen für die Superstringtheorie ebenso gegeben ist, wenn geschlossene Strings vorliegen; nur dass sich im Superstringansatz dann auch noch fermionische Zustände beschreiben lassen: Materie und vielleicht alle Wechselwirkungen innerhalb eines einheitlichen Ansatzes also. Gegenüber den Erfahrungen mit den Quantenfeldtheorien, die für die starke und die elektroschwache Wechselwirkung jeweils autonome Ansätze bemühen mussten, und die im Hinblick auf die Einbeziehung der Gravitation bisher erfolglos geblieben waren, würde mit einem solchen Ansatz, so war man überzeugt, eine signifikante Kontingenzminderung und Einheitlichkeit einhergehen: ${ }^{169}$

\section{"[...] gravitation and gauge theory [...] occur naturally in string} theory [...] whereas in field theory they are optional extras that are introduced on phenomenological grounds [...]." (O'Raifeartaigh / Straumann (2000) 15)

Sehr schnell wurde den Beteiligten klar: Der Stringansatz, der nach den Entwicklungen in der Hadronenphysik so gut wie tot war, hatte entweder als vereinheitliche Beschreibung aller Wechselwirkungen Erfolg, oder eben gar nicht. Erst die Entdeckung der Spin-2-Zustände des String machte den Stringansatz, der für die Hadronenphysik faktisch aus dem Rennen war, überhaupt wieder interessant.

1974 begann auf diese Weise die Geschichte des Stringansatzes als intendierter vereinheitlichter Theorie aller Wechselwirkungen. Damit wurde für

169 Zudem deutete sich an, dass die Divergenzen einer quantenfeldtheoretischen Beschreibung der Gravitation für den Stringansatz aufgrund der Ausgedehntheit der Strings und ihrer Wechselwirkungszonen ausbleiben. 
den Stringansatz aber auch ein völlig veränderter Motivationshintergrund wirksam: Es ging auf einmal um die Beseitigung von konzeptionellen Unverträglichkeiten innerhalb der Physik, insbesondere der Unvereinbarkeiten zwischen Quantenfeldtheorien und Allgemeiner Relativitätstheorie; es ging um die Vereinigung aller Wechselwirkungen und damit auch um die hinter dem Vereinigungsprogramm stehenden naturphilosophischen Grundannahmen wie etwa die einer Einheit der Natur. ${ }^{170}$

"To restate the situation, what was originally an attempt at a bottomup theory of hadrons, had a new incarnation as a top-down theory entirely motivated by theoretical concerns." (Schnitzer (2003) 4)

Es kann gar nicht überbetont werden, dass dieser Wandel hinsichtlich des intendierten Bezugs des Stringansatzes und der Motivationen, die für diesen neuen Bezug geltend gemacht werden konnten, sich wiederum - wie schon die gesamte Vorgeschichte des Stringansatzes - ausschliesslich im Bereich des Konzeptionellen und seiner modelltheoretischen Ausformungen bewegte und keinesfalls etwa durch irgendwelche neuen empirischen Daten zustandegekommen ist.

\section{Konzeptionelle Weiterentwicklung}

Aber trotz der hochfliegenden neuen Perspektive, als Kandidat für eine vereinheitlichte Theorie aller Wechselwirkungen anzutreten, blieb der Stringansatz in der Folgezeit erst einmal weitgehend unbeachtet. Die damals zeitweise unter der Bezeichnung Spinning String Theory formierende Neveu-Schwarz-Ramond-Superstringtheorie hatte immer noch eine ganze Reihe von ungelösten innertheoretischen Inkonsistenzen und konzeptionellen Problemen, die den Ansatz wenig attraktiv machten und dazu führten, dass er zwischen 1977 und 1983 im Stillen von einer sehr geringen Zahl von Theoretikern weiterentwickelt wurde.

$\mathrm{Zu}$ den vorrangigen innertheoretischen Problemen zählte nicht zuletzt die Tatsache, dass in der frühen Neveu-Schwarz-Ramond-Variante einer supersymmetrischen Stringtheorie immer noch tachyonische Zustände

$\overline{170 \quad \text { Siehe hierzu Kap. 4.2. }}$ 
auftraten - dieselben, die schon den alten bosonischen Theorien Schwierigkeiten bereitet hatten. Dieses Problem, das die Akzeptierbarkeit der Theorie entscheidend in Frage stellte, wurde schliesslich 1977 von Ferdinando Gliozzi, Joel Scherk und David Olive durch ein erst einmal rein formales Verfahren gelöst, das danach als GSO-Projektion bezeichnet wurde. ${ }^{171}$ Als Schlüssel zur Lösung des Problems tachyonischer Instabilitäten stellte sich die schon für die Einbeziehung von fermionischen Zuständen erforderliche Supersymmetrie heraus. Die GSO-Projektion nutzt diese im alten NeveuSchwarz-Ramond-Ansatz immerhin schon implizit enthaltene Supersymmetrie aus, um das Tachyon aus dem Spektrum der Stringzustände zu entfernen.

"Historically, a projection was made onto a set of definite G-parity states thus eliminating the tachyon and also rendering the spectrum space-time supersymmetric." (Alvarez-Gaumé / Vázquez-Mozo (1992) 105)

Die im Neveu-Schwarz-Ramond-Ansatz implizite Supersymmetrie, die nur für das String-Weltblatt manifest ist, wird in der Reparametrisierung der Dynamik durch die GSO-Projektion in eine manifeste Supersymmetrie der zehndimensionalen Raumzeit umgewandelt.

"After the GSO projection, the spectrum of the fermionic string becomes supersymmetric. This is rather surprising because having started with a action that was supersymmetric only on the world-sheet and we obtain in the end supersymmetry in the target space." (AlvarezGaumé / Vázquez-Mozo (1992) 106)

Die GSO-Projektion mag erst einmal vielleicht als physikalisch unmotiviertes, formal-mathematisches Verfahren erscheinen. Es gibt jedoch, wie sich allerdings erst nach ihrer Einführung zeigen liess, gute Argumente dafür, die GSO-Projektion nicht als Ad-hoc-Verfahren anzusehen: Sie ist vielmehr die notwendige Konsequenz grundlegender Invarianzbedingungen, die für die Konsistenz des Stringansatzes zu fordern sind, wenn globale Gravitationsanomalien vermieden werden sollen. ${ }^{172}$ Die GSO-Projektion ist nachweislich unabdingbar, wenn die raumzeitliche Supersymmetrie, die für die Einbeziehung fermionischer Zustände erforderlich ist, nicht 
schon manifest, sondern nur implizit im Ansatz enthalten ist. Die GSOProjektion beseitigt also gerade solche Probleme des Stringansatzes, die sich erst durch eine nur implizite Berücksichtigung der Supersymmetrie ergeben; diese erweisen sich im Rahmen der GSO-Projektion als Artefakte einer unangemessenen, nicht manifest supersymmetrischen Formulierung.

"The tachyon that appears in the bosonic string model, for example, is eliminated because it violates supersymmetry." (Kaku (1999) 102)

Insofern ist die GSO-Projektion die unabdingbare Therapie eines modelltheoretischen Problems, welches überhaupt erst durch das Beschreiten eines konzeptionellen Umweges entstanden ist, den der Stringansatz infolge seiner - mangels hinreichender physikalischer Intuitionen - oft recht planlosen Vorgehensweise bei der Modellbildung genommen hat. Ist dieser Umweg erst durch die GSO-Projektion als solcher entlarvt, wird dieses Verfahren hinfällig. ${ }^{173}$

Auch wenn sich konsequenterweise später Formulierungen der Superstringtheorien ergeben sollten, die keine GSO-Projektionen mehr nötig hatten, weil sie sich schon durch eine manifeste raumzeitliche Supersymmetrie auszeichneten, ${ }^{174}$ war die GSO-Projektion historisch von erheblicher

173 Die GSO-Projektion und die sie überhaupt erst erforderlich machende, planlose modelltheoretische Vorgehensweise könnten möglicherweise ein Bild im Kleinen für das liefern, was sich hinsichtlich des Stringansatzes in Bezug auf die eigentlich intendierte Theorie der Quantengravitation schliesslich herausstellen könnte: dass der Stringansatz vielleicht eine infolge mangelnder physikalischer Motivationen beschrittene Vorgehensweise darstellt, die ihre Relevanz und Daseinsberechtigung verliert, sobald sie zur tieferen Einsicht in die grundlegenden physikalischen Zusammenhänge und ihre adäquate theoretische Erfassung geführt hat, und sich dadurch selbst als wissenschaftshistorischen Umweg entlarvt. Dies würde aber auch bedeuten, dass man den Stringansatz, auch wenn er nicht schon die intendierte Theorie der Quantengravitation sein sollte, sehr ernst nehmen sollte, solange man keine besseren Konzepte vorweisen kann, die auf physikalischen Intuitionen, Ideen und Prinzipien beruhen, für die man eine unabhängige konzeptionelle oder gar empirische Motivation anführen kann.

174 In der späteren Green-Schwarz-Formulierung des Superstringansatzes ist dann eine GSO-Projektion schliesslich nicht mehr erforderlich (und auch gar nicht mehr möglich), da die Green-Schwarz-Formulierung schon eine manifeste raumzeitliche Supersymmetrie enthält. Dafür ist die Green-Schwarz-Formulierung recht umständlich zu handhaben und nur im Lichtkegel-Verfahren zu quantisieren, nicht aber mit kovarianten Verfahren. Die Green-Schwarz-Formulierung ist äquivalent zur Neveu-SchwarzRamond-Formulierung nach erfolgter GSO-Projektion. 
Bedeutung: Die Möglichkeit einer unterschiedlichen Wahl für die Projektionsoperatoren führte insbesondere zu der Einsicht, dass es neben dem ursprünglichen Neveu-Schwarz-Ramond-Ansatz, der später als Typ I bezeichnet werden sollte, noch weitere mögliche Formulierungen einer supersymmetrischen Stringdynamik gibt; diese wurden später als Typ IIA und IIB bezeichnet. ${ }^{175}$ Mit der GSO-Projektion zeigte sich aber vor allem, dass die ursprünglich für die Berücksichtigung von fermionischen Zuständen gewählte Strategie, nämlich die Einbeziehung der Supersymmetrie in den Stringansatz, grundsätzlich in die richtige Richtung führt.

Dennoch litt der Stringansatz Ende der siebziger und Anfang der achtziger Jahre immer noch an massiven innertheoretischen Problemen, die vor allem durch diverse resistente Anomalien ausgelöst wurden. ${ }^{176}$ Diese hingen nicht zuletzt mit den Modalitäten der Quantisierung des klassisch-relativistischen Strings zusammen. ${ }^{177}$ Sie machten deutlich, dass immer noch keine adäquate Prozedur für die Quantisierung der entsprechenden klassischen Dynamik, die als Ausgangspunkt diente, erreicht worden war. Dies sollte sich erst 1984 in einiger Hinsicht ändern.

\section{Die erste Superstring-Revolution}

1984 zeigten John Schwarz, Michael Green, André Neveu und Pierre Ramond, dass die Anomalien, mit denen der Superstringansatz immer noch zu kämpfen hatte und die seine innertheoretische Konsistenz ebenso wie seine Akzeptierbarkeit als physikalische Theorie grundlegend in Frage stellten, sich aufheben bzw. verhindern lassen, wenn die intendierten Symmetrien, insbesondere die Supersymmetrie, in der mathematischen

175 Siehe Kap. 2.1. sowie Green / Schwarz / Brink (1983).

176 "By definition an anomaly is a breakdown of a classical symmetry by quantum corrections." (Alvarez-Gaumé / Vázquez-Mozo (1992) 26)

"Simply, anomalies arise whenever the symmetries of the classical action do not carry over to the quantum level. The classical symmetries do not survive the process of regularizing the quantum theory." (Kaku (1999) 341)

Diese Anomalien werden vor allem dann zum Problem, wenn sie Eichinvarianzen, die Diffeomorphismus-Invarianz oder die konforme Invarianz betreffen.

177 Siehe hierzu die ausführlicheren Erörterungen am Ende dieses Teilkapitels. 
Formulierung der Theorie in spezifischer Weise berücksichtigt werden. ${ }^{178}$ Mit der Verhinderung der Anomalien sind spezifische Festlegungen für die Theorie und ihre inhärenten Symmetrien verbunden, die nur wenige konsistente Möglichkeiten lässt:

"An interesting feature of string gauge theories is that the choice of gauge group is quite limited." (O'Raifeartaigh / Straumann (2000) 15)

Die Festlegungen hinsichtlich der zu erwartenden Symmetrien schürte zudem die Hoffnung, die im Standardmodell der Quantenfeldtheorien auftretenden Eichinvarianzen schliesslich als Konsequenz des Stringansatzes ableiten zu können. Insbesondere die $\mathrm{E}_{8} \times \mathrm{E}_{8}$-Eichgruppe, die schliesslich als konsistente Möglichkeit im Stringansatz auftauchte, war schon vorher im Gespräch für die Grosse Vereinheitlichung von starker und elektroschwacher Wechselwirkung, da sie die Eichinvarianzen des Standardmodells als Untergruppen enthält.

"[...] the cancellation of anomalies in string theory places stringent conditions on which gauge groups may be allowed by the theory. Basically, the gauge group of a supersymmetric theory must contain exactly 496 generators, which restricts us to either $S O(32)$ or $E_{8} x E_{8} . "$ (Kaku (1999) 338)

Alle damals bekannten relevanten Randbedingungen, ebenso wie die Erfahrungen mit früheren Ansätzen, die noch eine GSO-Projektion erforderlich machten, wurden innerhalb der Green-Schwarz-Formulierung des Stringansatzes berücksichtigt: einer Theorie mit manifester raumzeitlicher Supersymmetrie. Die Green-Schwarz-Superstringtheorie machte zudem plausibel, dass für die Stringdynamik keine Singularitäten in den FeynmanDiagrammen möglicher Wechselwirkungen zu erwarten sind - und damit höchstwahrscheinlich keine Divergenzen:

"The discovery in 1984 by Green and Schwarz that the superstring theory is anomaly-free and probably finite to all orders of perturbation theory has revived the theory." (Kaku (1999) 16)

178 Siehe etwa Green / Schwarz (1984), Schwarz (1984), (1985) und (1987), Green (1985) sowie Green / Schwarz / Witten (1987). 
Vor dem Hintergrund der Erfahrungen mit dem Versuch der perturbativen (kovarianten) Quantisierung der Gravitation, die nicht nur einfach zu Divergenzen, sondern zu nicht-renormierbaren Divergenzen führte, machte dies den Superstringansatz nun auf einmal zu einem vielversprechenden Programm. Die schon lange gehegte Vermutung, dass sich die Gravitation vielleicht nur gemeinsam mit den anderen Wechselwirkungen konsistent beschreiben lässt, gewann wieder an Boden. Vielleicht, so dachte man, hebt eine Einbeziehung der Gravitation in einem gemeinsamen Ansatz, der auch alle anderen Wechselwirkungen einbezieht, sogar die im Standardmodell der Quantenfeldtheorien auftretenden, renormierbaren Divergenzen gänzlich auf und macht damit problematische Renormierungsverfahren obsolet. Vielleicht, so vermuteten nun zunehmends immer mehr theoretische Physiker, ist der Superstringansatz der aussichtsreichste, wenn nicht der einzige Kandidat für eine Realisierung dieser Hoffnung. Eine divergenzfreie, konsistent formulierbare und offensichtlich konkurrenzlose Theorie, die quasi von selbst Vektor- und Tensorbosonen liefert, erschien jedenfalls in dieser Hinsicht vielversprechend. Und mit dieser Einschätzung stieg die Zahl der Stringtheoretiker - bis 1984 wohl einstellig - um ein Vielfaches an. Nicht zuletzt aus diesem Grund werden die Entwicklungen im Jahre 1984 heute aus der historisch-mythologischen Perspektive heraus oft als "Erste Superstring-Revolution" bezeichnet.

"Thus was string theory born. To my mind, this is the most amazing thing about string theory - that it exists at all." (Weingard (1989) 151)

Die Theorie war jedoch - wie sich wohl fast alle Beteiligten eingestanden immer noch alles andere als vollständig, problemfrei und abgerundet. Die Entwicklungen in den achtziger und frühen neunziger Jahren dienten entsprechend vor allem der Systematisierung und dem Ausbau des Ansatzes sowie der Formulierung neuer Darstellungsmethoden (wie etwa der mittels konformer bzw. superkonformer Feldtheorien auf der Grundlage von KacMoody-Algebren). ${ }^{179} 1985$ wurden die beiden heterotischen Stringtheorien entwickelt, ${ }^{180}$ die das Spektrum der konsistent formulierbaren Varianten mit den schon bekannten Theorien den Typs I, IIA und IIB auf insgesamt fünf perturbative Stringtheorien erweiterten. ${ }^{181}$ Insbesondere die heteroti-

179 Vgl. Kaku (1999), Kap. 4. Kac-Moody-Algebren sind unendlich-dimensionale Verallgemeinerungen der Lie-Algebren.

180 Siehe Kap. 2.1. sowie Gross / Harvey / Martinec / Rohm (1985).

181 Siehe Kap. 2.1. 
sche Theorie mit der $\mathrm{E}_{8} \times \mathrm{E}_{8}$-Eichgruppe wurde erst einmal als aussichtsreichster Kandidat für die Reproduktion des quantenfeldtheoretischen Standardmodells angesehen, da ihre Eichinvarianz die des Standardmodells als Untergruppen enthält.

Die zu dieser Zeit intensiv diskutierten Probleme betrafen nicht zuletzt den Umgang und die Interpretation der für die Stringtheorien aus Konsistenzgründen erforderlichen höheren Dimensionalität. Die Idee der Kompaktifizierung $^{182}$ und der Rekurs auf die alte Kaluza-Klein-Theorie, ${ }^{183}$ welche Gravitation und Elektromagnetismus gemeinsam auf einer fünfdimensionalen Raumzeit erfassen sollte, machte die höhere Dimensionalität des Stringansatzes und ihre Verbindung mit der Vereinheitlichungsidee zunehmend plausibler. Immerhin ging es jetzt nicht mehr um zwei, sondern um vier Wechselwirkungen. (Dass deren einheitliche Beschreibung nur mit deutlich mehr als fünf Dimensionen erreicht werden kann, erscheint nicht mehr ganz so exotisch, wenn man sich die Kaluza-Klein-Theorie in Erinnerung ruft.) Zudem hoffte man, im Rahmen der Untersuchung möglicher Kompaktifizierungsmodi einen Weg zu finden, die Symmetriebrechungen nachvollziehbar machen zu können, die wahrscheinlich erforderlich sind, um für den Niederenergiebereich die Eichgruppen des quantenfeldtheoretischen Standardmodells aus den Eichinvarianzen des Stringansatzes abzuleiten. Diese Bestrebungen führten jedoch zu nichts. Nahezu alle Versuche, aus dem Stringansatz eindeutige Resultate abzuleiten, scheiterten an der Komplexität der involvierten Mathematik. Und es wurde schliesslich immer deutlicher, dass die Ursache dafür in einem fundamentalen Problem des Stringansatzes begründet lag: Auch nach der Einbeziehung der Supersymmetrie hatte man immer noch nicht mehr als einen ausschliesslich perturbativen Ansatz zur Verfügung. Es war - und ist heute noch - vollkommen unklar, wie eine nicht-perturbative Stringtheorie aussehen könnte und welche physikalischen Prinzipien ihr zu Grunde liegen könnten bzw. müssten. Die "Zweite Superstring-Revolution", auch wenn mit ihr grundlegende konzeptionelle Einsichten verbunden waren, sollte hier nur graduelle Abhilfe schaffen:

\footnotetext{
182 Siehe Kap. 2.2.

183 Siehe Kap. 1.
} 


\section{Die zweite Superstring-Revolution}

Fünf perturbative Stringtheorien sind einerseits mindestens vier zuviel und andererseits genau eine, durch physikalisch motivierte Prinzipien gestützte, stringente, nicht-perturbative Theorie zu wenig. Dies war nicht zuletzt der Grund dafür, dass die Begeisterung für den Stringansatz Anfang der neunziger Jahre stagnierte. Um 1995 kam es dann aber zu entscheidenden neuen Entwicklungen. Diese begannen mit einem - aufgrund begrenzter modelltheoretischer Mittel - eher zaghaften extrapolativen Vorstoss in den nichtperturbativen Bereich der Stringdynamik, den Bereich jenseits der perturbativen Stringtheorien, und führten von da aus zur Einsicht in die Verbindung zwischen den vorliegenden fünf perturbativen Stringtheorien. ${ }^{184}$

Die Überraschung, welche die im Nachhinein als solche apostrophierte "Zweite Superstring-Revolution" auslöste, bestand in der Entdeckung diverser Dualitätsbeziehungen ${ }^{185}$ zwischen den fünf perturbativen Superstringtheorien - auch wenn das Vorliegen dieser Dualitäten manchen Stringtheoretikern im Nachhinein nicht mehr ganz so überraschend erscheinen mag:

"Duality symmetries are most manifest in supersymmetric theories, because in such theories perturbative loop corrections tend to be suppressed, due to cancellations between bosonic and fermionic degrees of freedom." (Lerche (2000) 20)

Die T-Dualität etwa lieferte eine Begründung dafür, weshalb innerhalb des Stringansatzes die Divergenzen scheinbar gänzlich ausbleiben, die im Rahmen einer quantenfeldtheoretischen Behandlung der Gravitation zu offensichtlich unlösbaren Problemen führten, weil sie wohl grundsätzlich nicht-renormierbar sind. Früher hatte man das Ausbleiben der Divergenzen anschaulich auf die Ausgedehntheit der Strings und ihrer Wechselwirkungszonen zurückgeführt. Mit der T-Dualität lag aber nun eine wesentlich stringentere Begründung dafür vor.

Wiederum war es aber vor allem die Supersymmetrie, die für den Fortgang des Stringansatzes und für das Wiederaufleben des Stringenthusiasmus von

$\begin{array}{ll}184 & \text { Siehe Kap. 2.3. } \\ 185 & \text { Siehe Kap. 2.3. }\end{array}$


entscheidender Bedeutung war. Denn erst die infolge der Einsicht in die Existenz supersymmetrischer BPS-Zustände erschliessbare S-Dualität ermöglichte einen zumindest punktuellen Vorstoss in den nicht-perturbativen Bereich der Stringdynamik. Sie machte Verbindungen zwischen den fünf perturbativen Superstringtheorien deutlich, lieferte Hinweise auf eine elfte Dimension und legte schliesslich die Existenz einer fundamentaleren, den perturbativen Stringtheorien zugrundeliegenden, allerdings bis heute unspezifizierten, nicht-perturbativen Theorie nahe: der M-Theorie. Heute geht man davon aus, dass die perturbativen Stringtheorien die für spezifische Parameterbereiche gültigen Näherungen zu dieser M-Theorie darstellen, also einer spezifischen Koordinatenwahl im Parameterraum dieser grundlegenderen Theorie entsprechen. Es bleibt aber weiterhin offen, wie eine solche fundamentalere Theorie formuliert werden könnte. Es ist unklar, wie die unterschiedlichen Parameter, für die die perturbativen Stringtheorien stehen, gedeutet werden können. Und es ist vor allem vollkommen ungeklärt, welche physikalisch motivierbaren Prinzipien der M-Theorie zugrundeliegen könnten. Auch die Entdeckung nicht-perturbativer Phänomene wie etwa der p- und D-Branen haben diesbezüglich keinen Aufschluss gebracht. ${ }^{186}$ Man vermutet zur Zeit, dass eine grundlegende nichtperturbative Theorie ohne Rekurs auf eine Hintergrundraumzeit zu formulieren wäre. ${ }^{187}$

Trotz aller Fortschritte: Der Stringansatz weist nach wie vor nicht die geringste Motivation aus bestehender Empirie ${ }^{188}$ und nicht die geringste auf quantitativen Vorhersagen beruhende empirische Testmöglichkeiten ${ }^{189}$ auf, sondern stützt sich bisher ausschliesslich auf rein mathematische Konsistenzforderungen, modifizierte und erweiterte quantenfeldtheoretische Prozeduren sowie Ad-hoc-Festlegungen hinsichtlich seiner modelltheoretischen Grundlage. Entsprechend ist auch die Reproduktion der phänomenologisch beobachtbaren Niederenergiephysik, die im Stringansatz, der sowohl Fermionen als auch Skalar-, Vektor- und Tensor-Bosonen als Zustände enthält, zumindest konzeptionell unproblematisch erscheint, bisher nicht über den Bereich des Konzeptionellen hinaus zu konkreten Vorhersagen gediehen.

\footnotetext{
$186 \quad$ Siehe Kap. 2.4.

187 Vgl. Kap. 6.

188 Siehe Kap. 4.2.

189 Siehe Kap. 4.3.
} 
"Sal - [...] Would you agree in saying that the theory is well understood perturbatively, where it does not look like the real world, and we have only glimpses on its nonperturbative regime, but not yet a clear relation with our world?" (Rovelli (2003) 9)

Es gibt keine quantitativen und nur wenige qualitative Voraussagen. Nicht einmal die Ableitung der für den Niederenergiebereich zu erwartenden Eichinvarianzen ist bisher geglückt.

"The gauge groups it produces are to big, and finally, while it predicts fermions, it is not clear how to get fermionic matter with the structure we see, for example generations." (Giddings (2005) 8)

\section{Das Pferd von hinten aufzäumen: Zufallsentdeckungen und tentative Mathematik}

Viele der an der Entwicklung des Stringansatzes massgeblich beteiligten Theoretiker, wie etwa Edward Witten, betonen den Zufallscharakter dieser Entwicklung und das mangelnde physikalische Verständnis ihrer bisherigen Ergebnisse:

"Die Theorie wurde [...] von niemandem absichtlich geschaffen, sie verdankt ihre Entdeckung vielmehr einem glücklichen Zufall. Von Rechts wegen dürften die Physiker des 20. Jahrhunderts nicht das Privileg besitzen, diese Theorie zu untersuchen. Sie hätte nicht eher geschaffen werden dürfen, als unser Wissen auf einigen Gebieten, deren Kenntnis Voraussetzung für das Verständnis der Theorie ist, genügend weit entwickelt worden wäre, um uns die richtigen Vorstellungen darüber zu erlauben, was das alles zu bedeuten hat." (Witten in: Davies / Brown (1992) 129)

Zufälle prägten die gesamte bisherige Entwicklung des Stringansatzes. Zuerst wurde eine mathematische Formel entdeckt, die Eulersche Betafunktion, welche die Streumatrix für Hadronenkollisionen reproduzierte, ohne dass man wusste, wie es dazu kam. Dann wurde entdeckt, dass das aus dieser Übereinstimmung abgeleitete theoretische Modell der quantisierten 
Dynamik von klassisch-relativistischen Strings entsprach. Schliesslich fand man heraus, wie sich mittels der Supersymmetrie Fermionen in den Ansatz implementieren liessen. Als der Stringansatz in der Hadronenphysik dann schon erledigt war, entdeckte man die Gravitonenzustände der Stringoszillation. Damit kam es zu einem Strategiewechsel: Wenn der Stringansatz sich überhaupt für irgendetwas eignen sollte, dann nur als vereinheitlichte Beschreibung aller Wechselwirkungen. Auch nach diesem Strategiewechsel waren es immer wieder mehr oder weniger zufällige Entdeckungen, die den Stringansatz am Leben hielten und vorantrieben: die Entdeckung der Dualitätsbeziehungen, die der elften Dimension bei starker Kopplung sowie schliesslich die der Branen. Diese Entdeckungen waren nun jedoch, im Gegensatz zum Strategiewechsel von der Hadronenphysik zur vereinheitlichten Theorie, ausschliesslich auf den Ansatz selbst und seine internen konzeptionellen Probleme bezogen, Sie betrafen nicht mehr die externe Frage, was durch den Ansatz überhaupt zu modellieren sei. ${ }^{190}$ Parallel dazu wurden gezielt Lösungsansätze für theorieintern auftretende Probleme erwogen, wie etwa auf die Frage, wie man mit den aus Konsistenzgründen zu fordernden zehn Raumzeitdimensionen umgehen könnte. Hier kam die Kompaktifizierungsidee ins Spiel. Aber auch die Entdeckung der Branen spielte hier schliesslich eine Rolle.

Der Stringansatz ist das Ergebnis einer ausschliesslich konzeptionell bestimmten Entwicklung, die bis heute ohne fundamentale Prinzipien als Ausgangspunkt auskommen muss, also nicht von diesen ausgehend eine adäquate modelltheoretische Basis wählen konnte. Für ein von modellinternen Anforderungen unabhängiges, physikalisch motiviertes, fundamentales Prinzip hätte man vermutlich eine empirische Basis benötigt, die es für den Stringansatz nie gegeben hat. ${ }^{191}$ Vor allem, weil der Stringansatz nicht von irgendeiner physikalischen Intuition oder Idee ausgehend entwickelt wurde, konnte der Zufall bei seiner Ausformung eine solch entscheidende Rolle spielen.

"[...] why does superstring theory work at all - where does it come from? Unlike other quantum field theories, it is not based on some profound physical understanding. Rather, it has been 'plucked out of the air'." (Matthews (1994) 31) 
Das Fehlen eines von modellinternen Anforderungen unabhängigen, physikalisch motivierten, fundamentalen Prinzips, auf dem eine wirkliche physikalische Theorie der Quantengravitation aufbauen könnte, ist das grundlegende Charakteristikum, welches die Entwicklung des Stringansatzes bestimmten und prägten. Anders als die Allgemeine Relativitätstheorie, die vom Äquivalenzprinzip bzw. vom Prinzip der allgemeinen Kovarianz ausgehend motiviert werden kann, und anders als die Quantenfeldtheorien, denen Eichprinzipien ${ }^{192}$ zugrundegelegt werden können, ist der Stringansatz eben keine Theorie, die aus irgendeinem, unabhängig motivierten physikalischen Prinzip abgeleitet wurde oder im Nachhinein auf dieses bezogen werden könnte.

"In gauge theory and in general relativity, one starts with a spacetime symmetry principle. In string theory, too, it would seem that we should first figure out what the full spacetime symmetry is, and use this to define the theory. There are various attempts in this direction, but a complete picture has not yet emerged." (Polchinski (2000) 28)

Anstatt mit einer grundlegenden physikalischen Idee zu starten, aus der sich ein modelltheoretischer Entwurf entwickeln liesse, beginnt die Entwicklung des Stringansatzes mit einem - aus dem Rückblick - völlig willkürlichen modelltheoretischen Ansatz, der ursprünglich nicht einmal für den Bereich der Quantengravitation formuliert wurde, für den er dann nach dem durch die Entdeckung der Gravitonenzustände eingeleiteten Strategiewechsel schliesslich eingesetzt werden sollen. Das gewählte modelltheoretische Instrumentarium musste dazu über diverse Entdeckungen und Überraschungen hinweg, jeweils infolge innertheoretischer Konsistenzforderungen ad hoc modifiziert werden. Die Suche nach einem ihm zugrundeliegenden physikalischen Prinzip hält immer noch an.

Ohne grundlegendes physikalisches Prinzip und auf einer insofern auch nicht physikalisch motivierten modelltheoretischen Grundlage versucht der Stringansatz, sich über die schrittweise Modifikation und Erweiterung des modelltheoretischen Instrumentariums seiner erhofften physikalischen Prinzipienbasis anzunähern - sozusagen in einer konzeptionellen Rückwärtsbewegung. Diese konzeptionelle Rückwärtsbewegung und der aus ihr resultierende zum Teil skurrile und bizarre Charakter des Stringansatzes

192 Zu dem möglicherweise hinter der formalen Eichinvarianz stehenden physikalischen Prinzip siehe Lyre (2004). 
wird nicht nur von seinen Kritikern betont; auch etwa der Stringtheoretiker Michio Kaku weist darauf in einem seiner Lehrbücher zur Stringtheorie in drastischen Worten hin:

"Ironically, although superstring theory is supposed to provide a unified field theory of the Universe, the theory itself often seems like a confused jumble of folklore, random rules of thumb, and intuitions. This is because the development of superstring theory has been unlike that of any other theory [...]. Superstring theory [...] has been evolving backward for the past 30 years. It has a bizarre history [...]. [...] physicists have ever since been trying to work backward to fathom the physical principles and symmetries that underlie the theory. [...] the fundamental physical and geometrical principles that lie at the foundation of superstring theory are still unknown." (Kaku (1999) vii f)

Es ist während des gesamten Verlaufs der Entwicklung des Stringansatzes nicht gelungen, diese von einer zufällig als Ausgangspunkt gewählten modelltheoretischen Basis ausgehende, konzeptionelle Rückwärtsbewegung hin zu den unbekannten basalen physikalischen Prinzipien, die man hinter der Theorie vermutet, umzukehren. Es kam bisher an keiner Stelle der Entwicklung zur Entdeckung grundlegender physikalischer Prinzipien, die dann zumindest post hoc zu einer Umkehrung der Argumentationsrichtung hätten führen können, zu einer "konzeptionellen Vorwärtsbewegung", innerhalb derer das modelltheoretische Instrumentarium in seiner Ausformung schliesslich einem physikalisch motivierten Ausgangspunkt unterworfen worden wäre, welcher dann die weitere Modifikation und Differenzierung in der Theorienentwicklung bestimmt hätte.

Und es ist die den gesamten bisherigen Entwicklungsgang des Stringansatzes bestimmende konzeptionelle Rückwärtsbewegung, die vorrangig dafür verantwortlich ist, dass diese Entwicklung sich in vieler Hinsicht von der anderer physikalischer Theorien unterscheidet. Keine andere physikalische Theorie hat sich bisher in dem Masze wie der Stringansatz durch die Vorgehensweise hervorgetan, die diesen vor allem auszeichnet. Diese Vorgehensweise könnte man als "tentative Mathematik" bezeichnen - ein möglichst umfassendes Ausloten des modelltheoretischen Möglichkeitsraums. Was bleibt einem rein modelltheoretischen Ansatz mit physikalischen Ambitionen auch anderes übrig, wenn er weder über entscheidende physikali- 
sche Intuitionen, noch über eine empirische Basis ${ }^{193}$ verfügt, als die Möglichkeiten auszuloten, die in seinem Instrumentarium begründet sind?

Die tentative Mathematik des Stringansatzes besteht einerseits im mehr oder weniger systematischen Durchspielen aller mathematischen Möglichkeiten innerhalb des jeweilig gewählten konzeptionellen und modelltheoretischen Kontextes sowie andererseits im Ausloten der sich anbietenden konzeptionellen Modifikationen dieses Kontextes. Die erste dieser Strategien dient vor allem dazu, die konsistenten Formulierungen zu sondieren. Aber erst mittels der zweiten Strategie lässt sich eine Annäherung an das gesuchte physikalische Prinzip erhoffen. Die Begrenzung der Möglichkeiten erfolgt in beiden Fällen vor allem durch mathematische Konsistenzforderungen und erst in zweiter Linie durch physikalische Plausibilitätsüberlegungen.

Ziemlich schnell stellt sich jedoch heraus, dass das vollständige Durchspielen aller Möglichkeiten innerhalb des gewählten modelltheoretischen Ansatzes und erst recht über diesen hinaus, sich nicht vollends systematisch bewältigen lässt. Konsequenterweise wird das Systematische der tentativen Mathematik in ihrer schieren und unüberschaubaren Fülle im Stringansatz oft durch konzeptionelle Intuitionen kanalisiert:

"Unfortunately, we have no guiding principle for the construction of the interacting theory except for intuition." (Kaku (1999) 111)

Die dabei verwendeten Intuitionen sind wiederum vor allem modelltheoretischer Natur. Schon die Erfassung der den Stringwechselwirkungen zugrundeliegenden Invarianzen im frühen Neveu-Schwarz-Ramond-Formalismus, der ersten Formulierung einer Superstringtheorie, ist beispielhaft für dieses Vorgehen im Stringansatz. Mögliche physikalisch relevante Implikationen, wie etwa die der Supersymmetrie, ergeben sich, wenn überhaupt, nur als Konsequenzen modelltheoretischer Bemühungen, nicht aber etwa aufgrund empirischer Randbedingungen oder unabhängiger physikalischer Überlegungen; sie fliessen im Sinne der Ökonomisierung der Modellbildung erst post hoc in diese ein. Ob man mit dem Ergebnis dieser Rückbindung, dem Green-Schwarz-Formalismus, der schliesslich über eine manifeste Supersymmetrie verfügt, dann viel anfangen kann, ist eine ganz andere Frage:

$193 \quad$ Siehe Kap. 4.2. und 4.3. 
"The reader may feel that the [...] Ramond-Neveu-Schwarz (RNS) form of the superstring [...] is somewhat ad hoc. In particular one might expect that the spacetime supersymmetry should be manifest at the start. There is certainly truth to that, but the existing supersymmetric formulation (the Green-Schwarz superstring) seems to be even more unwieldy." (Polchinski (2000a) 29)

Bei der konkreten Ausformulierung und dem "Durchrechnen" der modelltheoretischen Ansätze ergeben sich oft hochkomplexe byzantinische Rechenlabyrinthe, die nicht nur den Leser von Lehrbüchern zur Stringtheorie, sondern ebenso deren Autoren, nach vielen Seiten mathematischer Ableitungen, Näherungen, Ad-hoc-Annahmen und Plausibilitätsüberlegungen, mit Ratlosigkeit zurücklassen, weil sich kein definitives, verwertbares Ergebnis einstellt. ${ }^{194}$ Insbesondere die Umsetzung der Konsistenzforderungen hinsichtlich der zulässigen Symmetriegruppen erinnert in ihrer konkreten mathematischen Ausformulierung oft an Zahlenmagie: Hauptsache, man kommt an Ende auf die 496 Generatoren der Symmetriegruppe, egal aus welchen unterschiedlichen Klassen diese nun auch zusammenaddiert werden müssen. ${ }^{195}$

Es sind bizarre, heterogene Konstrukte wie etwa die heterotischen Theorien, denen zumindest zeitweise die höchste Plausibilität zugeschrieben wurde, das Standardmodell der Elementarteilchenphysik ableitbar werden $\mathrm{zu}$ lassen.

"You have to go, say, to the heterotic string, with gauge groups, superfields ..., a different behavior of the two halves of the theory ... I wouldn't call this an extremely simple picture." (Rovelli (2003) 4)

Und dies, obwohl schon bei der Entwicklung der heterotischen Theorien den Beteiligten eigentlich klar war, dass ihre spezifische Ausformulierung nicht das letzte Wort sein würde, sondern eben eine tentative Annäherung, die vor allem durch das gerade verwendete modelltheoretische Instrumentarium bestimmt ist:

194 Siehe etwa die einschlägigen Lehrbücher zur Stringtheorie: Polchinski (2000) und (2000a) sowie Kaku (1999).

195 Siehe wiederum die einschlägigen Lehrbücher zur Stringtheorie: Polchinski (2000) und (2000a) sowie Kaku (1999). 
"It is certainly true that the formulation of the heterotic string appears somewhat awkward and contrived. This is not a shortcoming of our theory; rather it is indicative of the present level of understanding of all quantum string theories, which leaves much to be desired. Many of the most remarkable features of these theories emerge without a full comprehension of their origin. Most mysterious are the general coordinate invariance and local gauge symmetries of string theories, whose appearance lacks a geometrical explanation. This suggests that there exists a more profound formulation of string theory, in which these features would be manifest. In such a formulation the heterotic theory might appear more natural." (Gross / Harvey / Martinec / Rohm (1985) 282)

Und richtig: Nach der nächsten Überraschungswelle - mit der Entdeckung der Dualitätsbeziehungen und der Einsicht, dass alle perturbativen Stringtheorien ineinander überführbar sind, - sind die heterotischen Theorien dann auch als Anwärter für die Reproduktion des Standardmodells weitgehend überholt. Die Präferenz für einen spezifischen perturbativen Ansatz ergibt unter diesen Bedingungen keinen rechten Sinn mehr. Und spätestens mit dem Landscape-Szenario und der Analyse der Statistik von Stringvakua hat sich die Frage, ob die heterotischen Theorien die besten Aussichten für die Reproduktion des Standardmodells liefern, dann vollständig erledigt. ${ }^{196}$

Man kann sich nun fragen: Was ist eigentlich die Ursache für die bisherige weitgehende Erfolglosigkeit der tentativen Mathematik, des möglichst umfassenden Durchrechnens des modelltheoretischen Möglichkeitsraums und der Auslotung seiner möglichen Erweiterungen und Modifikationen, für das Bizarre der sich auf der jeweils gewählten modelltheoretischen Grundlage ergebenden Formulierungen des Stringansatzes, für die Umwege und Sackgassen in seiner Entwicklung? - Vielleicht verwendet der Stringansatz schlichtweg eine wenig angemessene und wenig geeignete mathematische Grundlage, um den Bereich der Quantengravitation und der nomologischen Vereinheitlichung aller Wechselwirkungen angemessen zu erfassen. Vielleicht arbeitet er mit der falschen modelltheoretischen Grundlage. Vielleicht verwendet er die falsche Mathematik.

$196 \quad$ Siehe Kap. 5. 
Solange für den Bereich der Quantengravitation keine empirische Basis und kein wirklich überzeugendes, unabhängig von den Labyrinthen der Modelltheorie motivierbares, physikalisches Prinzip vorliegt, wird es sehr schwierig sein, eine adäquate modelltheoretische Grundlage für eine Theorie der Quantengravitation zu finden bzw. die Adäquatheit einer einmal gewählten modelltheoretischen Grundlage tatsächlich einschätzbar werden zu lassen. Letztlich sollten physikalische Prinzipien, die eine empirische Fundierung aufweisen, die modelltheoretische Basis einer Theorie festlegen. Es ist aber wahrscheinlich nicht möglich, für einen Wirklichkeitsbereich zutreffende physikalische Prinzipien aus labyrinthischen Manövern im Bereich modelltheoretischer Selbstläufer zu erraten oder gar abzuleiten.

Diese Einsicht kommt aber im Stringansatz nur unzureichend zum tragen. Michio Kaku etwa vermutet in seinem Lehrbuch zur Stringtheorie, dass das Problem der falschen Mathematik zwar existiert, aber auf den Kontext der anzuwendenden Quantisierungsvorschriften begrenzt ist. ${ }^{197}$ Er geht davon aus, dass die entscheidenden modelltheoretischen Probleme des Stringansatzes und das Bizarre seiner Ausformulierung darauf zurückzuführen sind, dass dieser im wesentlichen in erster Quantisierung, also als Quantentheorie klassischer Strings, und nur ansatzweise in zweiter Quantisierung, also als Feldquantisierung der Stringdynamik ${ }^{198}$ im Sinne der Quantenfeldtheorien, vorliegt:

"The great irony of string theory, however, is that the theory itself is not unified. To someone learning the theory for the first time, it is often a frustrating collection of folklore, rules of thumb, and intuition. At times, there seems to be no rhyme or reason for many of the conventions of the model. For a theory that makes the claim of providing a unifying framework for all physical laws, it is the supreme irony that the theory itself appears so disunited! The secrets of the model, at its most fundamental level, are still being pried loose. / Usually when we write down a quantum theory, we start from the geometry or symmetry of the theory and then write down the action. From the action, in turn, we derive all the predictions of the model, including the unitary $S$ matrix. Thus, a second quantized action is the proper way in which to

$197 \quad$ Siehe Kaku (1999).

198 Einen Überblick über die Stringtheorie in der zweiten Quantisierung, die sogenannte "String Field Theory", und ihre Probleme geben etwa Siegel (1989) und Taylor (2006). 
formulate a quantum field theory. The fundamental reason why superstring theory seems, at times, to be a loose collection of apparently random conventions is that it is usually formulated as a first quantized theory." (Kaku (1999) 5)

Ob dies nun die Ursache der Probleme ist oder nicht: Die Nachteile einer Darstellung in der ersten Quantisierung sind nicht von der Hand zu weisen. Die Theorie bleibt notwendigerweise immer perturbativ und die Wechselwirkungen müssen ad hoc zusätzlich eingefügt werden.

"[...] a first quantized theory requires additional assumptions. In particular, the vertices, the choice of interactions, and the weights of these perturbation diagrams must be postulated by hand and checked to be unitary later." (Kaku (1999) 49)

Von der Theorie zu erwartende, relevante Vorhersagen, etwa hinsichtlich der dynamischen Symmetriebrechungen, sind im Rahmen einer Formulierung in erster Quantisierung nicht ohne weiteres erreichbar:

"Most important, the first quantized string theory is unsuitable for a calculation of dynamical symmetry breaking." (Kaku (1999) 247)

Eine Darstellung in der zweiten Quantisierung hätte demgegenüber, wie Kaku herausstreicht, entscheidende Vorteile: Die Mechanismen der dynamischen Symmetriebrechung liessen sich zumindest im Prinzip berechnen. Die Motivation für die Existenz von Wechselwirkungen beruhte auf gruppentheoretischen Argumenten. Diesen läge das Postulat zugrunde, dass die einzigen zugelassenen Wechselwirkungen solche sind, die instantan die lokale Topologie der beteiligten Strings ändern. ${ }^{199}$

199 Die einzig möglichen Wechselwirkungstypen wären die, die durch Öffnung, Schliessung, Aufspaltung und Fusion von Strings zustandekommen:

1. offener String <---> zwei offene Strings (Aufspaltung / Anbindung)

2. zwei offene Strings <---> zwei offene Strings überkreuz

(Aufspaltung und Anbindung)

3. geschlossener String <---> zwei geschlossene Strings (Abnabelung / Einbindung)

4. offener String <---> offener String und geschlossener String

(Abnabelung / Einbindung)

5. geschlossener String <---> offener String (Öffnung / Schliessung)

Siehe etwa die Abbildung auf Seite 262 in Kaku (1999). 
"Because all the symmetries have been extracted out in the light cone gauge, there is no overall guiding priniciple for the theory. We will, therefore, simply postulate the following prinicple: / The only interacting string configurations that are allowed in the action are those that instantaneously change the local topology of strings. / Although this principle is defined only in the light cone gauge, we will find that it is sufficient to determine all the possible interactions of the field theory." (Kaku (1999) 262)

Kakus eigene Darstellung des Stringansatzes in zweiter Quantisierung lässt jedoch nicht deutlich werden, dass hierbei weniger Ad-hoc-Elemente verwendet werden als in der Darstellung in erster Quantisierung. So schreibt er selbst hinsichtlich der Einbeziehung der Supersymmetrie in die Darstellung des Stringansatzes in zweiter Quantisierung:

"We have now assembled a formidable apparatus, mostly constructed by guesswork and analogies from the bosonic case." (Kaku (1999) 285)

Und am Ende von Kakus Ausführungen haben sich dann die Hoffnungen auf eine nicht-perturbative Superstringtheorie in zweiter Quantisierung, die sogenannte "String Field Theory", als nicht einlösbar erwiesen:

"String field theory, although it is defined independently of perturbation theory, is currently too difficult to solve for the nonperturbative region." (Kaku (1999) 457)

Diese Feststellung wiederholt sich fast wortgleich mehrere Male, fast wie ein Mantra:

"String field theory, although it is defined independent of perturbation theory, has proven too difficult to formulate and solve." (Kaku (1999) 543)

Bleibt nur, auf zukünftige Durchbrüche zu hoffen: ${ }^{200}$

200 Bis heute haben sich diese noch nicht eingestellt, wie etwa Taylor (2006) deutlich macht, obwohl er sicherlich mit seiner Darstellung ganz andere Ziele verfolgt. 
"[...] string field theory is still an evolving subject. As a result, it has not yet lived up to its promise of yielding nonperturbative information about string theory. Although string field theory is defined independent of perturbation theory, it is still too difficult to perform nonperturbative calculations." (Kaku (1999) 328)

Ob das grundlegende Problem des Stringansatzes aber wirklich in seiner Darstellung in erster Quantisierung zu sehen ist, ist fraglich. Die im Glossar zu Joseph Polchinskis zweibändigem Lehrbuch zur Stringtheorie vorzufindenden Ausführungen zur ersten, zweiten und dritten Quantisierung in den Quantenfeldtheorien und im Stringansatz lassen Kakus Argumentation hinsichtlich der Ursachen der Probleme in ihrer letztendlichen Relevanz zumindest fragwürdig erscheinen:

"[A] first-quantized description [is] the representation of a quantized particle theory as a sum over particle paths, or of a string theory as a sum over world-sheets. Second-quantized refers to the representation in terms of a functional integral over ordinary or string fields. The term second-quantized implies the reinterpretation of the first-quantized wavefunction as a field operator. This terminology is in common usage, but it has been argued that it is unsatisfactory, in that it implies a deep principle where none may exist. / Since the sum over worldsheets is itself a quantum field theory, one can equally well call it second-quantized, in which case string field theory is third-quantized. Third quantization of an ordinary field theory would describe operators that create and destroy universes, a concept which may or may not be useful." (Polchinski (2000a) 497f)

Und schliesslich könnte es ganz andere Probleme geben, die einen Erfolg des Stringansatzes verhindern könnten, als die aus seiner Darstellung in erster Quantisierung resultierenden - solche etwa, die auch im Rahmen einer "String Field Theory" nicht überwindbar wären:

"[...] if strings are the wrong degrees of freedom for writing down the full Hamiltonian, no bookkeeping device like string field theory will give a satisfactory description." (Polchinski (2000a) 210)

Spätestens hinsichtlicher der M-Theorie ist Kakus Einschätzung, dass die Lösung des grundlegenden Problems des Stringansatzes in einer Darstel- 
lung in zweiter Quantisierung zu sehen ist, ohnehin schon nach seiner eigenen Feststellung hinfällig:

"We should point out, however, that second quantization has been developed only for string theory, not M-theory. In fact, it is not known how to formulate M-theory in a satisfactory first quantized formalism, let alone a second quantized one." (Kaku (1999) 248)

Ob also eine Darstellung des Stringansatzes in zweiter Quantisierung etwas am oben konstatierten Zustand der konzeptionellen Rückentwicklung ohne fundamentale Prinzipien ändern könnte, ist sehr zweifelhaft. Hinsichtlich dieser konzeptionellen Rückentwicklung hat sich jedenfalls bis heute nichts Entscheidendes geändert.

"Currently, string theorists are in a position analogous to an Einstein bereft of the equivalence principle. Since Veneziano's insightful guess in 1968, the theory has been pieced together, discovery by discovery, revolution by revolution. But a central organizing principle that embraces these discoveries and all other features of the theory within one overarching and systematic framework - a framework that makes the existence of each individual ingredient absolutely inevitable - is still missing. [...] There is, of course, no guarantee that such a fundamental principle exists, but the evolution of physics during the last hundred years encourages string theorists to have high hopes that is does." (Greene (1999) 375f)

Es bleibt letztlich völlig unklar, ob der Stringansatz überhaupt zu irgendwelchen für den Bereich der Quantengravitation und der Vereinigung aller Wechselwirkungen relevanten physikalischen Prinzipien hinführen wird oder ob dazu ein anderer Weg beschritten werden müsste.

Was hält aber den Stringansatz am Leben? Wieso wird er mit höchster Intensität weiterverfolgt, trotz seiner völlig untypischen Entwicklung ohne empirische Anbindung, trotz seiner geradezu bizarren Ausformungen, trotz der Bedeutung von Zufallsentdeckungen als vorantreibendem Element, trotz seines Einsatzes tentativer Mathematik, trotz fehlender empirischer Überprüfbarkeit und trotz mangelnder physikalischer Prinzipien, die diesem allem zugrundeliegend könnten? - Die Antwort ist im Grunde einfach: Weil der Stringansatz die besten zur Zeit verfügbaren Aussichten einerseits 
auf die Lösung konzeptioneller Probleme der Physik und andererseits auf die Realisierung eines ihrer ältesten metaphysischen Programme bietet! Davon - und von der Fokussierung auf das Konzeptionelle aufgrund fehlender empirischer Ankopplung - soll nun detaillierter die Rede sein. 


\subsection{Konzeptionelle Randbedingungen}

Bei der gesamten Entwicklung des Stringansatzes spielten nur mathematisch-modelltheoretische Konsistenzüberlegungen und einige wenige physikalische Plausibilitätsüberlegungen eine Rolle, nie jedoch Erfordernisse oder Ergebnisse einer direkten Ankopplung an die Empirie. Dies unterscheidet den Stringansatz von fast allen früheren Theorieentwicklungen in der Physik. Fast immer waren es empirische Daten, die mit den bestehenden Theorien nicht erklärbar waren, die zur Entwicklung neuer Theorien führten oder zumindest nach deren Entwicklung für diese geltend gemacht werden konnten. Zur Quantenmechanik etwa kam es überhaupt erst aufgrund empirischer Befunde, die im Kontext der klassischen Physik nicht erklärbar waren: die Strahlung schwarzer Körper, die Atomspektren, die Interferenzmuster in Streuexperimenten am Doppelspalt oder der Photoeffekt. Die Spezielle Relativitätstheorie konnte sich, auch wenn bei ihrer Entwicklung vor allem konzeptionelle Randbedingungen eine Rolle spielten, zumindest post hoc auf die im Michelson-Morley-Experiment deutlich werdende Konstanz der Lichtgeschwindigkeit berufen. Diese entsprach den Vorhersagen der klassischen Maxwellschen Elektrodynamik, war aber mit der klassischen Newtonschen Physik unverträglich. Die Spezielle Relativitätstheorie korrigierte die Newtonsche Physik, um die Verträglichkeit mit der Elektrodynamik und den empirischen Befunden wiederherzustellen. Die Glashow-Salam-Weinberg-Theorie der elektroschwachen Wechselwirkung schliesslich beruhte einerseits auf den die schwache Wechselwirkung betreffenden empirischen Befunden, die etwa beim radioaktiven Zerfall zutage treten, und andererseits auf der Tatsache, dass es nicht möglich war, eine autonome Quantenfeldtheorie der schwachen Wechselwirkung konsistent zu formulieren, ohne auf nicht-renormierbare Divergenzen zu stossen. In der Glashow-Salam-Weinberg-Theorie wurde dieses Problem dann durch die nomologische Vereinigung von schwacher und elektromagnetischer Wechselwirkung in einer Weise gelöst, die mit den schon bestehenden und den bald nach ihrer Entwicklung hinzukommenden empirischen Befunden in Einklang stand. Die Vereinigung von schwacher und elektromagnetischer Wechselwirkung wurde im Zusammenspiel von empirischen und konzeptionellen Randbedingungen unabdingbar. Die neu entstandene Theorie gelangte insbesondere sehr schnell zu empirischen Vor- 
hersagen, die sich ziemlich schnell experimentell bestätigen liessen. - Beim Stringansatz ist dies grundlegend anders.

\section{Fehlende empirische Randbedingungen für eine Theorie der Quantengravitation}

Es gibt nicht die geringsten empirischen Befunde, welche den Stringansatz oder irgendeine andere Form einer Quantengravitationstheorie erforderlich machen würden. Alle vorhandenen empirischen Daten stehen im Einklang mit dem Standardmodell der Quantenfeldtheorien bzw. mit der Allgemeinen Relativitätstheorie.

"We have today a group of fundamental laws, the standard model and [general relativity], [...] there aren't today experimental facts that openly challenge or escape this set of fundamental laws." (Rovelli (1998) 2)

Es gibt keine positive empirische Instanz, die für die Notwendigkeit des Stringansatzes oder irgendeiner anderen Form einer Quantengravitationstheorie spräche.

"Therefore, we have no direct empirical guidance for searching for quantum gravity - as, say, atomic spectra guided the discovery of quantum theory." (Rovelli (2004) 4)

Alle Argumente, die für den Stringansatz als Motivationen bemüht werden können oder im Rahmen seiner Entwicklung eine Rolle spielen konnten, beruhen auf ausschliesslich konzeptionellen Überlegungen. Die Allgemeine Relativitätstheorie ist eine der wenigen Theorien, die hinsichtlich dieser Problemlage zumindest Parallelen mit dem Stringansatz aufweist. Hier war es vor allem die Idee der konzeptionellen Vereinheitlichung, die für Einsteins Ansatz in seiner Entwicklung bestimmend war. Allerdings, ganz im Gegensatz zum Stringansatz, liessen sich bald nach Entwicklung der Allgemeinen Relativitätstheorie Vorhersagen machen, die empirisch überprüft werden konnten und kurz darauf zur Bestätigung der Theorie beitrugen. Für den Stringansatz sind es aber nach über dreissig Jahren im- 
mer noch ausschliesslich die konzeptionellen Randbedingungen, die seine Entwicklung und Ausformung bestimmen, mittlerweile über viele konzeptionelle Modifikationsstufen hinweg.

"If it succeeds in providing a description of nature it will be one more example of a 'top down' theory, i.e. one which is driven by theoretical issues, and not by experiment, at least not in its formative stages. [...] There are well recognized 'top-down' theories in our own subject; 1) general relativity; 2) the Dirac theory of the electron; and 3) the non abelian gauge theories, (i.e. Yang-Mills theory) are prime examples. Each of these were also theories in search of experiments, and they are with us today because eventual confirming experimental results became available." (Schnitzer (2003) 2)

Die maximale Form der empirischen Ankopplung, die der Stringansatz aufweist, besteht in der indirekt und implizit einbezogenen Phänomenologie, die schon in die ihm vorausgehende Physik Eingang gefunden hat und sich nun im Rahmen seiner Entwicklung über die für ihn wirksam werdenden konzeptionellen Randbedingungen partiell auf ihn überträgt: eine sehr indirekte, partielle und selektive Berücksichtigung von empirischen Daten also, die von seinen Vorgängertheorien schon umfassend reproduziert werden.

Und es ist wirklich nur ein Teil der schon in die Vorgängertheorien eingeflossenen Phänomenologie, der inhaltlich in die sukzessive Differenzierung des Stringansatzes eingeht. Einige der entscheidendsten Komponenten, die sich - aus der Phänomenologie kommend - für eine Theorie der Quantengravitation als interessant erweisen könnten, werden nämlich schon im Rahmen der "Theorienselektion", aus der der Stringansatz als bedenkenswerte physikalische Konzeption hervorgeht, aufgebraucht. So lässt sich vor allem die Phänomenologie der Gravitation eigentlich schon nicht mehr zur empirischen Ausgangsbasis für den Stringansatz zählen, da erst die Tatsache, dass der Stringansatz in der Lage ist, die Allgemeine Relativitätstheorie als Niederenergienäherung zu reproduzieren, ihn überhaupt wieder ins Rennen gebracht hat. Hätte der Stringansatz nicht diese Eigenschaft, würde niemand mehr von ihm reden.

Ähnlich steht es um die grundsätzliche, phänomenologisch motivierbare Struktur der anderen Wechselwirkungen, die nicht etwa in konkreter Form 
in den Stringansatz eingeht, sondern vielmehr - wie die Gravitation - zufällig und unerwartet von ihm reproduziert wird. Der Stringansatz erweist sich als mit dem Prinzip der Eichsymmetrie verträglich und scheint damit grundsätzlich in der Lage zu sein, die Eichinvarianzen des Standardmodells, aber auch ziemlich viele andere, zu reproduzieren. Erst die Reproduktion der Gravitation und der Eichinvarianzen führten jedoch dazu, dass der Stringansatz als vereinheitlichte Theorie aller Wechselwirkungen auftreten kann, also dazu, dass man sich überhaupt für ihn interessiert.

Über die schon in dieser "Theorienselektion" aufgebrauchten phänomenologischen Randbedingungen hinaus gibt es jedoch immerhin noch eine Reihe von Voraussetzungen, die den indirekten empirischen Gehalt des Stringansatzes und seiner Ausformulierungen ausmachen. Es sind theoretische Konzepte, die aus den Vorläufertheorien stammen und schon für diese durch die vorliegende Empirie hinreichend motiviert sind: Die LorentzInvarianz der Speziellen Relativitätstheorie und die Unitarität der Quantenmechanik etwa fliessen über die Virasoro- bzw. die Super-VirasoroAlgebren direkt in den Stringansatz und die internen Konsistenzforderungen, die seine explizite Formulierung bestimmen, ein. Sie führen nicht zuletzt zur Festlegung der Raumzeitdimensionen im Stringansatz. Die phänomenologisch erschliessbare Existenz von fermionischen (dem Paulischen Ausschlussprinzip genügenden) und bosonischen Feldern, Materie und Wechselwirkungen also, und insbesondere die Chiralität der fermionischen Felder haben den Stringansatz in der Weise beeinflusst, dass supersymmetrische Formulierungen gesucht und gefunden wurden, und dass mit der Einbeziehung der Supersymmetrie - durch hinzukommende modelltheoretische Konsistenzforderungen - zusätzliche Festlegungen hinsichtlich der Theorienstruktur getroffen wurden. Die Vierer-Raumzeit, die sich uns in der Phänomenologie als solche darstellt, ist mit dem Stringansatz aufgrund seiner internen Festlegungen, die zu einer zehn bzw. elfdimensionalen Raumzeit führen, erst einmal nicht vereinbar; sie führte aber dazu, dass nach theorieinternen Lösungen für diese anscheinende Unvereinbarkeit gesucht wurde: für das Problem also, wie die Vierer-Raumzeit mit der Zehner-Raumzeit der Stringtheorien und der Elfer-Raumzeit der M-Theorie zu vereinbaren sein könnte. Kompaktifizierungsmodelle und Branwelt-Szenarien bieten hierzu Lösungen an. Insgesamt gilt: Relevante empirische Randbedingungen haben sich als solche, die schon in die Vorgängertheorien Eingang gefunden haben, in die Theorienbildung des Stringansatzes über dessen konzeptionelle Randbedingungen eingeschrieben. 
Aber eigentlich sollte eine umfassende Theorie diese Phänomenologie nicht einfach nur voraussetzen, sondern zumindest zum Teil erklärbar werden lassen. Beim Stringansatz ist dies bisher nicht der Fall. Er kommt überhaupt nur als physikalische Theorie in Frage, weil es (i) so aussieht, als ob er die Phänomenologie, die schon in die Vorläufertheorien Eingang gefunden hat, grundsätzlich zu reproduzieren in der Lage sein könnte, und weil er (ii) gleichzeitig das regulative Ideal des physikalischen Vereinheitlichungsprogramms in formaler Hinsicht erfolgreich umsetzt.

\section{Die grundlegende Motivation für den Stringansatz}

Der entscheidende Faktor, durch den der Stringansatz interessant erscheinen könnte, ist, dass er eine konsistente Realisierung des physikalischen Vereinheitlichungsgedankens verspricht. - Das basalste Ziel des physikalischen Vereinheitlichungsprogramms ist das Erreichen der konzeptionellen Vereinbarkeit der verschiedenen Bereiche der Physik.

"Many of the most striking advances in theoretical physics have derived from the effort of finding a common theoretical framework for two basic and apparently conflicting discoveries." (Rovelli (2004) 5)

Für den Stringansatz manifestiert sich dieses Ziel im Versuch der Überwindung der Konflikte zwischen Quantenmechanik und Allgemeiner Relativitätstheorie. Aber seine Ziele gehen weit darüber hinaus. Es geht nicht nur um die konsistente Formulierung einer Theorie, mittels derer die Unvereinbarkeit von Quantenmechanik und Allgemeiner Relativitätstheorie überwunden werden kann, sondern es geht beim Stringansatz um eine nomologisch vereinheitlichte Theorie, mittels derer alle Wechselwirkungen in einem einheitlichen Wurf zusammenfinden.

Dass es sowohl hinsichtlich der konzeptionellen Vereinheitlichung als auch in Bezug auf die nomologische Vereinigung nur konzeptionelle Motivationen gibt, nicht aber empirische Daten, die mit den bestehenden Theorien unvereinbar wären, wurde soeben schon betont. Wie gut sind aber die konzeptionellen Motivationen? - Vor einer Erörterung dieser Frage ist es sinn- 
voll, noch einmal etwas dezidierter auf die Unterschiede zwischen den Projekten der konzeptionellen Vereinheitlichung und der nomologischen Vereinigung einzugehen, und diese durch einige Beispiele zu veranschaulichen. $^{201}$

\section{Arten der Vereinheitlichung}

Eine konzeptionelle Vereinheitlichung hat vor allem das Ziel, Unvereinbarkeiten zwischen unterschiedlichen physikalischen Theorien aufzuheben. Dies ist spätestens da unabdingbar, wo sich Überschneidungen im Gegenstandsbereich miteinander unvereinbarer Theorien ergeben. Die im Rahmen der konzeptionellen Vereinheitlichung angestrebte Einheit der Wissenschaft besteht in ihrer grundlegendsten Form in der Vermeidung von logischen und konzeptionellen Widersprüchen zwischen wissenschaftlichen Theorien. Es geht also darum, die verschiedenen theoretischen Konzeptionen zumindest insofern miteinander in Einklang zu bringen, dass sie sich in ihren Voraussetzungen und in ihren Ergebnissen nicht widersprechen. Dies macht im Falle eines Konfliktes die Modifikation mindestens einer der betroffenen theoretischen Ansätze erforderlich. Um aber nach einer solchen Modifikationen die erreichte Verträglichkeit der betroffenen Theorien überhaupt nachweisbar werden zu lassen, müssten diese spätestens nach der Modifikation in gewisser Weise modelltheoretisch vergleichbar sein. Die konzeptionelle Vereinheitlichung ist als gleichzeitig notwendigerweise eine modelltheoretische Vereinheitlichung. Die konzeptionelle Vereinheitlichung lässt sich nur auf der Grundlage einer modelltheoretischen Einheit erreichen.

Ein gutes Beispiel für eine erfolgreiche konzeptionelle Vereinheitlichung liefert die Spezielle Relativitätstheorie: Sie stellt das Ergebnis der Modifikation der Newtonschen Mechanik dar, die aufgrund ihrer Unvereinbarkeit mit der klassischen Elektrodynamik erforderlich wurde. Die Maxwellschen Gleichungen der klassischen Elektrodynamik sagen für elektromagnetische Wellen eine konstante und isotrope Ausbreitungsgeschwindigkeit vorher, nämlich die Lichtgeschwindigkeit. Dies widerspricht der Galilei-Invarianz der Newtonschen Mechanik, nach der für elektromagnetische Wellen, die

$201 \quad$ Vgl. Kap. 1 und 3. 
von einem bewegten Objekt ausgehen, eine Addition der Geschwindigkeiten und damit unterschiedliche Ausbreitungsgeschwindigkeiten der Wellen für unterschiedliche Richtungen zu erwarten wären. Mit dem Übergang von der Galilei-Invarianz der Newtonschen Mechanik zur Lorentz-Invarianz der Speziellen Relativitätstheorie wird dieses Problem gelöst. Die konstante und isotrope Ausbreitungsgeschwindigkeit elektromagnetischer Wellen ergibt sich mit der Lorentz-Invarianz der Speziellen Relativitätstheorie problemlos. Im Minkowski-Raum, der speziell-relativistischen Raumzeit, nehmen die Maxwell-Gleichungen der Elektrodynamik zudem eine sehr einfache Form an.

Die Unvereinbarkeit der Newtonschen Gravitationstheorie mit der auf diese Weise zustandegekommenen Speziellen Relativitätstheorie wurde dann schliesslich in der Allgemeinen Relativitätstheorie überwunden. Auf der Grundlage der Einsicht in die Äquivalenz von schwerer Masse und träger Masse wird die Raumzeit hier zu einer dynamischen Grösse, die mittels der Differentialgeometrie vierdimensionaler Riemannscher Mannigfaltigkeiten erfasst werden kann. Die Gravitation wird im Sinne einer Geometrodynamik mit der dynamischen Raumzeit und ihren differentialgeometrischen Eigenschaften identifiziert.

Eine weitere erfolgreiche konzeptionelle Vereinheitlichung stellt die (speziell-)relativistische Quantenmechanik dar. Sie wurde erforderlich aufgrund einer Behandlung von Raum und Zeit in der Quantenmechanik, die mit der speziellen Relativitätstheorie und ihrer Lorentz-Invarianz nicht vereinbar ist. Die Modifikation der Quantenmechanik in Form der Ersetzung der Schrödinger-Gleichung durch die entsprechenden relativistischen Gleichungen, die Klein-Gordon-Gleichung und Dirac-Gleichung, räumten dieses Problem aus. Gleichzeitig lieferte die relativistische Quantenmechanik die Basis für die Quantenstatistiken der Bosonen und Fermionen.

Die Quantenfeldtheorien brachten dann die Quantenmechanik, die klassische Feldtheorie und die Spezielle Relativitätstheorie durch eine Erweiterung der relativistischen Quantenmechanik auf Felder in Einklang. In der Feldquantisierung, auch als zweite Quantisierung bezeichnet, werden jedem Punkt der Raumzeit quantenmechanische Feldoperatoren zugeordnet. Die für die Erwartungswerte des Feldes im Rahmen perturbativer Rechenverfahren auftretenden Divergenzen werden im Rahmen der Renormierung mathematisch traktibel gemacht. Der konzeptionelle Preis dafür sind die 
nach der Renormierung nur noch empirisch fixierbaren freien Parameter. Das heutige Standardmodell der Quantenfeldtheorien verfügt zwar über voneinander unabhängige Theorien für die elektroschwache und für die starke Wechselwirkung. Diese sind jedoch aufgrund der analogen Vorgehensweise problemlos miteinander verträglich. Das Eichprinzip liefert für die Quantenfeldtheorien des Standardmodells eine gemeinsame Basis.

Ein Beispiel für eine zur Zeit vorangetriebene konzeptionelle Vereinheitlichung bietet die Kanonische Quantengravitation bzw. ihre neuere Variante, die Loop Quantum Gravity. ${ }^{202}$ Mit ihr sollen die Unvereinbarkeiten zwischen der Quantenmechanik und der Allgemeinen Relativitätstheorie überwunden werden. Die Konsequenz einer Quantisierung der Gravitation, wie sie von der Loop Quantum Gravity unternommen wird, wäre eine Theorie ohne Hintergrundraum. Die quantenmechanische Diskretisierung der Raumzeit soll diese als abgeleitete Grösse mit den entsprechenden dynamischen und relationalen Eigenschaften in ihrem Zustandekommen verständlich machen. Der Erfolg dieses Programms ist noch nicht abzusehen. (Aber immerhin ist die Loop Quantum Gravity ein Ansatz, der zielgerichtet auf der Grundlage physikalischer Prinzipien entwickelt wird und nicht etwa, wie der Stringansatz, zufällig sein Thema gefunden hat.)

Wesentlich ambitionierter als die konzeptionelle Vereinheitlichung ist das Programm der nomologischen Vereinigung. Hier geht es nicht einfach nur um die konzeptionelle und modelltheoretische Verträglichkeit unserer theoretischen Entwürfe, sondern darüber hinaus vor allem um die Gleichsetzung von Phänomenbereichen der Wirklichkeit bzw. um die Gleichsetzung von den diesen Phänomenbereichen zugrundeliegenden Prozessarten, die schliesslich innerhalb unserer naturwissenschaftlichen Erfassung der Wirklichkeit ihren Niederschlag finden sollte.

Hinter dem Programm der nomologischen Vereinigung steht die Idee einer Einheit der strukturierten Natur, die einer durchgängigen Gesetzmässigkeit unterworfen ist. Und diese Gesetzmässigkeit basiert auf den fundamentalen Prozessarten, die die Wirklichkeit bestimmen. Bei adäquater Vorgehensweise, so das Programm der nomologischen Vereinigung, sollte sich die gesetzesartige Grundlage bzw. die fundamentalen Prozessarten, deren Auswirkung die dynamischen Strukturen sind, die wir als Wirklichkeit bezeichnen, innerhalb ihrer naturwissenschaftlichen Erfassung widerspiegeln.

$202 \quad$ Siehe Kap. 3. 
Möglichst umfassende Phänomenbereiche - in letzter Instanz: die gesamte Wirklichkeit - sollen mittels einer einheitlichen nomologischen Erfassung auf das Wirken fundamentaler Prozessarten zurückgeführt werden. Wenn die Idee der Einheit der Natur zutrifft, sollte sich herausstellen, dass die fundamentalen Prozessarten, die die Welt bestimmen, alle zusammenhängen, sich vielleicht sogar auf eine einzige Prozessart reduzieren lassen, aus der alle anderen hervorgehen oder von der alle anderen Erscheinungsformen darstellen. Das regulative Ideal hinter diesem Ansatz entspricht dem Bestreben, das prozessuale Substrat und die für dieses geltenden grundlegenden gesetzmässigen Zusammenhänge auszumachen. Das Ziel ist letztlich und im günstigsten Falle also eine vollständige dynamische Theorie des Substrats.

Die fundamentalen Prozessarten sind nach unserem heutigen Verständnis die fundamentalen Wechselwirkungen. Und wenn die Idee der Einheit der Natur zutrifft, wäre zu erwarten, dass zwischen diesen Wechselwirkungen eine Verbindung hergestellt werden kann, sie vielleicht sogar auf einen gemeinsamen Ursprung zurückgeführt werden können. Die nomologische Einheit der Wirklichkeit - als das Resultat dieser fundamentalen Wechselwirkungen verstanden - wird also im heutigen physikalischen Vereinigungsprogramm so gedeutet, dass die phänomenologisch verschiedenen fundamentalen Wechselwirkungen einen gemeinsamen Ursprung haben, ihnen eine gemeinsame prozessuale Basis zugrundeliegt, es also letztlich nur eine basale Prozessart, nur eine Wechselwirkung, gibt, die in unterschiedlicher Weise in den Phänomenen zum Ausdruck kommt. Die Einheit der Wirklichkeit, die als nomologische Einheit verstanden wird, stellt sich in diesem Rahmen als Einheit der Prozesse dar, als Einheit der Wechselwirkungen.

Wenn diese Idee einer Einheit der Wirklichkeit als Einheit der Wechselwirkungen zutrifft, so hätte der Versuch, die Gravitation gemeinsam mit allen anderen Wechselwirkungen in einen einheitlichen Ansatz einzubeziehen, vielleicht gute Erfolgsaussichten. Genau dies versucht der Stringansatz. Genau dies macht ihn überhaupt für die Physik interessant.

Eine solche Vorgehensweise wäre nur dann unangemessen, wenn die Einheitsidee schlichtweg auf unsere Welt nicht zuträfe. Wir könnten es etwa mit einer Welt zu tun haben, die eben nicht einheitlich durchstrukturiert ist, sondern vielmehr einem Flickenteppich der Strukturen und Phänomene 
ähnelt. Wir könnten es mit einem pluralistischen Universum zu tun haben, mit einer irreduziblen Pluralität natürlicher Phänomenbereiche, die jeweils eine völlig eigenständige wissenschaftliche Vorgehensweise erfordern. ${ }^{203}$ Man benötigt also zumindest empirisch fundierte Anzeichen, die für die Einheit der Wechselwirkungen sprechen. Ohne solche empirisch fundierten Anzeichen bleibt das physikalische Vereinheitlichungsprogramm lediglich Ausdruck einer metaphysischen Idee. Dass es solche Anzeichen gibt, soll sogleich verdeutlicht werden. ${ }^{204}$

Was aber ebenso für die Idee einer nomologischen Einheit der Natur spricht, sind die Beispiele erfolgreicher nomologischer Vereinheitlichungen: Paradefälle in dieser Hinsicht sind die Newtonsche Physik, mit der die alte Trennung in irdische und Himmelsmechanik aufgehoben wurde, sowie die Maxwellsche Elektrodynamik, mit der die Zusammenführung von Elektrizität, Magnetismus und Optik gelang. Eines der besten neueren Beispiele für eine erfolgreiche nomologische Vereinigung ist das GlashowSalam-Weinberg-Modell der elektroschwachen Wechselwirkung. Das Glashow-Salam-Weinberg-Modell ist für den Stringansatz insbesondere deshalb interessant und - wie man hofft - paradigmatisch, weil es ein Beispiel dafür liefert, dass man eine konzeptionelle Vereinheitlichung manchmal nur um den Preis einer nomologischen Vereinigung erzielen kann. Nach der Entdeckung der schwachen Wechselwirkung versuchte man zuerst, im wesentlichen von den vierziger bis in die sechziger Jahre, diese mit den gleichen konzeptionellen Mitteln zu beschreiben, die schon beim Elektromagnetismus erfolgreich waren, nämlich denen der Quantenfeldtheorie. Das Ziel war eine Quantenfeldtheorie der schwachen Wechselwirkung analog zur Quantenelektrodynamik. Man kannte zwar die Phänomenologie der schwachen Wechselwirkung, aber alle Versuche, wie etwa das Fermi-Modell, diese im Rahmen einer Quantenfeldtheorie zu erfassen, scheiterten. Immer wieder stiess man auf nicht-renormierbare Divergenzen. Dann unternahmen Sheldon Glashow, Abdus Salam und Steven Weinberg Ende der sechziger Jahre schliesslich den Versuch, die schwache Wechselwirkung gemeinsam mit der elektromagnetischen Wechselwirkung im Rahmen eines einheitlichen quantenfeldtheoretischen Ansatzes zusam-

203 Siehe etwa Cartwright (1994), (1999) sowie (1983) und (1989). Vgl. auch Morrison (2000).

204 Siehe weiter unten in diesem Teilkapitel die Abschnitte "Motivationen für eine Theorie der Quantengravitation" und "Motivationen für eine nomologische Vereinigung aller Wechselwirkungen". 
menzufassen. 1971 konnte dann Gerard 't Hooft nachweisen, dass die auf diese Weise zustandekommende Glashow-Salam-Weinberg-Theorie nicht nur konsistent formulierbar, sondern auch renormierbar ist. Bald darauf liess sich nachweisen, dass sie mit den empirischen Befunden in Einklang steht. ${ }^{205}$ Und es liess sich schliesslich mittels des Konzepts der spontanen Symmetriebrechung erklären, wieso die niederenergetische Phänomenologie der elektromagnetischen und der schwachen Wechselwirkung unterschiedlich ausfallen.

Neben den Beispielen erfolgreicher nomologischer Vereinheitlichungen gibt es jedoch auch eine ganze Reihe von Versuchen einer nomologischen Vereinheitlichung, die ohne Erfolg blieben: ${ }^{206}$ Über dreissig Jahre lang, bis zu seinem Tode im Jahre 1955, versuchte Einstein mit seiner "Einheitlichen Feldtheorie" erfolglos die nomologische Einbeziehung der klassischen Elektrodynamik in das Geometrisierungsprogramm der Allgemeinen Relativitätstheorie. Auch das Wirken des Elektromagnetismus sollte als Ergebnis der raumzeitlichen Dynamik verstanden werden. Übrig bleiben sollte am Ende nur noch ein metrisches Feld und seine dynamischen Eigenschaften. Die mit der Speziellen Relativitätstheorie erreichte konzeptionelle Vereinbarkeit zwischen Elektrodynamik und Mechanik genügte Einstein nicht. Die von ihm angezielte Einheit der Physik sollte eine nomologische Einheit sein, welche die grundlegende strukturelle Einheit der Natur zum Ausdruck brächte. Der Versuch einer nomologischen Zusammenführung von Elektromagnetismus und Gravitation innerhalb des Geometrisierungsprogramms scheiterte jedoch.

John Wheeler unternahm dann schliesslich eine neuen, umfassenderen Versuch in diese Richtung: In Wheelers Quantengeometrodynamik sollten alle Materie und alle Wechselwirkungen als Ausdrucksformen dynamischer Geometrie und Topologie erfasst werden. Alle Phänomene sollten sich im Rahmen einer Geometrisierung, wie sie schon hinsichtlich der Gravitation innerhalb der Allgemeine Relativitätstheorie unternommen worden war, auf die Raumzeit abbilden lassen. Aber auch dieses ambitionierteste aller Geometrisierungsprogramme, innerhalb dessen sich die Welt

205 Mit dem Nachweis der W-Bosonen der schwachen Wechselwirkung (CERN, 1983) und der ebenso vorhergesagten "neutralen schwachen Ströme" (CERN, 1973) in Hochenergieexperimenten konnte die Glashow-Salam-Weinberg-Theorie empirisch bestätigt werden.

$206 \quad$ Vgl. für die ersten beiden Beispiele Kap. 1. 
in monistischer Weise als dynamische Geometrie darstellen sollte, blieb erfolglos. Die Quantengeometrodynamik scheiterte an den spätestens für die Planck-Ebene zu erwartenden Fluktuationen der Raumzeit. Deren Folge wären topologische Risse in der Raumzeit, die mit den Mitteln der Differentialgeometrie, wie sie der Wheelerschen Quantengeometrodynamik zugrunde lagen, nicht vereinbar sind.

Ein wesentlich jüngeres Beispiel für einen erfolglosen Versuch einer nomologischen Vereinigung, diesmal aus dem Kontext der zwischenzeitlich erfolgverwöhnten Quantenfeldtheorien, stellt die "Grand Unification" dar. Trotz der grossen Erwartungen nach dem Erfolg des nomologischen Vereinheitlichungsprogramms mit der Glashow-Salam-Weinberg-Theorie der elektroschwachen Wechselwirkung und trotz des Entwicklungspotentials, das die Quantenfeldtheorien nach der Formulierung der Quantenchromodynamik zur Beschreibung der starken Wechselwirkung vorzuweisen hatten, scheiterte die nomologische Vereinigung der elektroschwachen mit der starken Wechselwirkung, die beide als Ausdrucksformen einer fundamentaleren Kraft etablieren sollte. Es gab verschiedene Formulierungen für die intendierte "Grand Unified Theory" mit unterschiedlichen Symmetrien und unterschiedlichen Mechanismen der spontanen Symmetriebrechung hin zur "Niederenergiephysik" der Quantenchromodynamik und der GlashowSalam-Weinberg-Theorie. Aber alle postulierten notwendigerweise QuarkLepton-Übergänge. Deren Konsequenzen erwiesen sich jedoch als mit den empirischen Daten nicht verträglich. ${ }^{207}$ Und so blieb es beim Standardmodell, das sich in konzeptioneller Einheit additiv aus Quantenchromodynamik und Glashow-Salam-Weinberg-Theorie zusammensetzt, die sich bisher einer nomologischen Vereinigung verschlossen haben.

Der Stringansatz geht nun in seinen Ambitionen deutlich über die mit den Grand Unified Theories angestrebte nomologische Vereinigung der elektroschwachen mit der starken Wechselwirkung hinaus. Noch deutlicher geht er über eine rein konzeptionelle Vereinheitlichung unserer Beschreibung der Gravitation mit den für alle anderen Wechselwirkungen bestehenden quantenfeltheoretischen Beschreibungen hinaus. Sein Ziel ist also nicht einfach nur die Formulierung einer Theorie der Quantengravitation.

207 Das gängigste Modell mit einer SU(5)-Symmetrie beispielsweise sagte die Quark-Lepton-Übergänge mit Wahrscheinlichkeiten voraus, die zu einem Protonenzerfall mit einer Halbwertszeit unterhalb der experimentell nachweislichen Stabilität des Protons liegt. 
Vielmehr setzt er auf die vollständige nomologische Vereinigung aller Wechselwirkungen. Und dies tut er in der Einschätzung, dass sich sowohl die Probleme, die sich im Rahmen der Versuche, eine Grand Unified Theory zu formulieren, zeigten, als auch die Probleme, die eine konzeptionelle Vereinheitlichung zwischen Quantenmechanik und Allgemeiner Relativitätstheorie nahelegen, möglicherweise nur lösen lassen, wenn man alle Wechselwirkungen in einem einheitlichen Ansatz erfasst.

Wenn sich der Stringansatz als erfolgreich erweisen sollte, so würde dies nahelegen, dass eine minimale konzeptionelle und modelltheoretische Vereinheitlichung, deren Ziel die Etablierung einer Theorie der Quantengravitation ist, nur um den Preis einer umfassenden nomologischen Vereinigung hinsichtlich aller Wechselwirkungen erreicht werden kann. Mit dem Stringansatz würde sich dann für die Gravitation und alle anderen Wechselwirkungen das wiederholen, was mit der Glashow-Salam-WeinbergTheorie schon für die schwache und die elektromagnetische Wechselwirkung festgestellt werden musste. ${ }^{208}$ Wenn das Ausräumen von konzeptionellen Unverträglichkeiten zwischen etablierten Theorien nur mittels einer nomologischer Vereinigung erreicht werden kann, ist dies natürlich der beste Grund für eine solche nomologische Vereinigung und mithin für die hinter diesem Programm stehenden metaphysischen Grundannahmen. Die Einheit der Natur brächte sich in den Darstellungen, die unsere bestehenden Theorien von ihr entwerfen, in Form konzeptioneller Unverträglichkeiten zum Ausdruck, die mit einer simplen konzeptionellen Vereinheitlichung nicht behebbar wären, sondern geradezu die nomologische Vereinigung erzwingen würden. Auf diesem Wege wären wir geradezu zur Einsicht in die Einheit der Natur gezwungen.

Sind die bestehenden konzeptionellen Unverträglichkeiten aber tatsächlich von dieser Art? Ein etwas genauerer Blick auf die möglichen physikalischen Motivationen für unsere Bemühungen um eine vereinheitliche Theorie aller Wechselwirkungen bzw. um eine Theorie der Quantengravitation ist die notwendige Voraussetzung zur Erörterung dieser Frage. Aber ob

208 Der entscheidendste Unterschied zwischen dem Stringansatz und der GlashowSalam-Weinberg-Theorie besteht aber immer noch darin, dass letztere sehr schnell nach ihrer Formulierung empirische Bestätigungsinstanzen für sich geltend machen konnte, ersterer jedoch während der gesamten über drei Jahrzehnte seines Bestehens nicht einmal empirisch überprüfbare Vorhersagen zustandegebracht hat. Die Gründe dafür werden uns noch beschäftigen. Siehe Kap. 4.3. 
sich diese Frage überhaupt als beantwortbar erweisen kann, wird erst wenn überhaupt - die zukünftige Entwicklung der Physik zeigen können. Dennoch: Warum brauchen wir überhaupt eine Theorie der Quantengravitation oder gar eine vereinheitliche Theorie aller Wechselwirkungen? Worin bestehen die Unvereinbarkeiten der Bilder, die unsere besten etablierten Theorien von der Wirklichkeit entwerfen? Wenn, wie oben festgestellt, für eine Theorie der Quantengravitation schon keine empirischen Erfordernisse vorliegen, was sind dann also die konzeptionellen Probleme, die eine solche Theorie nahelegen? Worin genau bestehen die Konflikte zwischen Allgemeiner Relativitätstheorie und Quantenmechanik bzw. Quantenfeldtheorien?

\section{Motivationen für eine Theorie der Quantengravitation}

Die Sachlage stellt sich heute folgendermassen dar: Elementarteilchen sind, je nachdem welche "Quantenzahlen" sie besitzen, selektiv bestimmten der in den Quantenfeldtheorien beschriebenen Wechselwirkungen unterworfen. Sie wechselwirken aber grundsätzlich auch gravitativ. Wir verfügen jedoch über keine Quantenfeldtheorie der Gravitation, die uns eine konzeptionell einheitliche Beschreibung aller Wechselwirkungen, denen materielle Objekte unterworfen sind, ermöglichen würde.

\section{"According to classical General Relativity, the metric behaves deter- ministically, but of course this is inconsistent with the stochastic, quantum behavior of the matter to which the metric couples via the Einstein equation." (Sorkin (1997) 3)}

Nun könnte man sagen: Hier liegt zwar eine grundsätzliche konzeptionelle Uneinheitlichkeit vor. Das ist aber noch nicht wirklich spektakulär, wenn wir uns vor Augen führen, dass die Vorhersagen, die unsere besten bestehenden Theorien liefern, bisher immer mit den empirischen Daten übereinstimmten. Meistens kann man eben getrost darüber hinwegsehen, dass Elementarteilchen auch gravitativ wechselwirken. Oder man hat soviel Materie zusammen, dass zwar die gravitative Wechselwirkung wichtig ist, dafür aber die Quanteneigenschaften der Materie keine wirkliche Rolle mehr spielen. 
Spektakulärer - und äusserst problematisch - wird es aber zum Teil da, wo sich motivieren lässt, dass dies nicht mehr der Fall ist. Und dies betrifft nicht zuletzt die im Rahmen der Kosmologie und auf der Grundlage der Allgemeinen Relativitätstheorie vorhergesagten Raumzeitsingularitäten: also die für den Gravitationskollaps schwerer Sterne postulierten Schwarzen Löcher und die für den Anfang der Expansion des Universums postulierte Urknallsingularität.

\section{"[...] the simple structure of a black hole, can be used to probe and learn about the quantum structure of gravitation. As such, a black hole is considered by many as the gravitational equivalent of the hy- drogen atom in mechanics [...]." (Lemos (2005) 2)}

Schwarze Löcher etwa machen, wie sich leicht einsehen lässt, eine Berücksichtigung der Allgemeinen Relativitätstheorie wie der Quantenmechanik bzw. der Quantenfeldtheorien erforderlich: Sie kommen auf der Grundlage sehr starker Gravitationswirkungen zustande. Gemäss den Extrapolationen der Allgemeinen Relativitätstheorie werden sie durch eine Singularität beherrscht. Aber die Allgemeine Relativitätstheorie versagt bei Singularitäten, auch wenn sie sie in ihrem Zustandekommen vorhersagt. Sie beschreibt zwar die Bedingungen der Entstehung von Schwarzen Löchern, ist aber nicht mehr in der Lage, diese selbst in ihren Eigenschaften umfassend zu beschreiben, da das Äquivalenzprinzip für die Singularität selbst ungültig wird, so dass die Allgemeine Relativitätstheorie nicht mehr anwendbar ist. ${ }^{209}$ Singularitäten sind aber sicherlich auch kaum mit den Unschärfen innerhalb der Quantenmechanik in Einklang bringen.

Dennoch spielt die Quantenmechanik in diesem Kontext eine entscheidende Rolle. Denn Schwarze Löcher weisen physikalische Bedingungen auf, für die eine quantenfeldtheoretische Berücksichtigung der Gravitation - und damit ihre quantenmechanische Behandlung - unabdingbar wird. ${ }^{210}$ Dies wird insbesondere deutlich, wenn man versucht, die Allgemeine Relativitätstheorie und die Quantenfeldtheorien gleichzeitig bei der Beschrei-

209 Das gleiche gilt im wesentlichen auch für die postulierte Urknall-Singularität, nur dass hier mittels der Allgemeinen Relativitätstheorie auf diese zurückextrapoliert wird, sie selbst aber nicht mehr durch die Theorie beschrieben werden kann, weil hier wiederum das Äquivalenzprinzip nicht mehr gilt.

210 Vgl. Kap. 1. 
bung Schwarzer Löcher zum Einsatz zu bringen; es kommt zu kuriosen Widersprüchen: Schwarze Löcher sind gemäss der Allgemeinen Relativitätstheorie von einem Ereignishorizont umgeben, durch den materielle Objekte und Strahlung in das Schwarze Loch eindringen können. Aber nichts kann das Schwarze Loch verlassen, da die gravitative Anziehung so gross ist, dass nicht einmal Strahlung die Gravitationsanziehung überwindet, da die Fluchtgeschwindigkeit unterhalb des Ereignishorizontes grösser als die Lichtgeschwindigkeit ist. Schwarze Löcher haben auf jeden Fall eine Masse und in manchen Fällen darüberhinausgehend eine elektrische Ladung und einen Drehimpuls. ${ }^{211}$ Darin erschöpfen sich nach heutiger Auffassung ihre Eigenschaften. ${ }^{212}$ Die Ladung eines Schwarzen Loches etwa führt dazu, dass - im Bild der klassischen Physik - auf elektrisch geladene Probekörper ausserhalb des Ereignishorizontes eine Kraft ausgeübt wird. Im einfachsten, vielleicht etwas naiven Bild der Quantenfeldtheorien stellt sich diese Kraftwirkung als Ergebnis des Austausches von (virtuellen) Feldquanten dar. Diese Feldquanten der elektromagnetischen Wechselwirkung sind Photonen. - Wie können aber Photonen zwischen dem Schwarzen Loch und dem elektrisch geladenen Probekörper ausserhalb des Ereignishorizontes ausgetauscht werden, wenn kein Photon in der Lage ist - und dies ist gerade die Definition für ein Schwarzes Loch - die Gravitationsanziehung des Schwarzen Lochs zu überwinden, da die Fluchtgeschwindigkeit unterhalb des Ereignishorizontes grösser als die Lichtgeschwindigkeit ist? Vielleicht, so könnte man denken, können die virtuellen Photonen, die die elektrische Wechselwirkung vermitteln, gerade das Schwarze Loch verlassen, nicht aber die realen Photonen, die elektromagnetischer Strahlung entsprechen. Sicherlich sind virtuelle Photonen etwas gänzlich anderes als reale Strahlungsphotonen. Aber, auch wenn das Bild virtueller Photonen, die zwischen Ladungen ausgetauscht werden, den Quantenfeldtheorien nicht in vollem Masze angemessen sein mag: an dem Problem ändert dies letztlich nichts. Die Frage bleibt: Wie kommt irgendeine physikalische Wirkung aus dem Schwarzen Loch. Vielleicht durch irgendwelche

211 Schwarze Löcher mit einer Schwarzschild-Metrik haben ausschliesslich eine Masse. Für Schwarze Löcher mit einer Reissner-Nordström-Metrik kommt zur Masse eine Ladung hinzu. Schwarze Löcher mit einer Kerr-Metrik haben eine Masse und einen Drehimpuls und solche mit Kerr-Newman-Metrik verfügen schliesslich über das gesamte Spektrum der für Schwarze Löcher möglichen Eigenschaften: Masse, Ladung und Drehimpuls.

212 Im folgenden soll der Drehimpuls erst einmal unberücksichtigt bleiben, in der Hoffnung, dass dies am Argument nichts ändert. Dies entspricht einer Beschränkung auf Schwarze Löcher mit einer Reissner-Nordström-Metrik. 
nicht-lokalen Quanteneffekte? Sicherlich lässt sich hier spekulieren, aber die bestehenden Theorien bieten hierfür bisher keine überzeugende Erklärung. - Was sich über die Wirkung der elektrischen Ladung eines Schwarzen Loches sagen lässt, gilt natürlich auch für die gravitative Wirkung der Masse des Schwarzen Lochs auf Masseobjekte ausserhalb seines Ereignishorizontes. ${ }^{213}$

Es gibt eine ganze Reihe weiterer Problemlagen, die durch die Unvereinbarkeit der Allgemeinen Relativitätstheorie mit der Quantenphysik zustandekommen und sich erst innerhalb einer Theorie der Quantengravitation klären lassen werden: So postulierte Stephen Hawking 1974, dass

$213 \quad$ Als mögliche Reaktion auf diese Unvereinbarkeit unserer allgemein-relativistischen Vorstellungen von den Eigenschaften eines Schwarzen Lochs und dem Bild, das die Quantenfeldtheorien von den Wechselwirkungen liefern, sind grundsätzlich drei spekulative und mindestens zum Teil, wenn nicht gänzlich, kontrafaktische Szenarien denkbar:

1. Es gibt keine Schwarzen Löcher. Diese sind ein Artefakt der asymptotischen Unangemessenheit der Allgemeinen Relativitätstheorie und ihrer modelltheoretischen Grundlage. In der Natur kommen sie nicht vor. Dann wäre - etwa im Rahmen einer Theorie der Quantengravitation - zu erklären, weshalb ihre Vorhersage im Rahmen der Allgemeinen Relativitätstheorie falsch ist.

2. Es gibt Schwarze Löcher, so wie dies die Allgemeine Relativitätstheorie vorsieht, und ihre Masse und ihre Ladung sind von ausserhalb feststellbar, indem sie dort Wirkungen erzeugen. Dann wäre zu zeigen, wie diese Wirkungen auf der Quantenebene zustandekommen. Vielleicht sind die dem Schwarzen Loch zugeschriebenen Eigenschaften, also Masse, elektrische Ladung und Drehimpuls, solche, die sich bei seiner Entstehung in die Raumzeit um das Schwarze Loch herum oder in seinen Horizont eingeschrieben haben. Dann wären die vermeintlichen Wechselwirkungen zwischen dem Schwarzen Loch und seiner Umwelt eigentlich solche zwischen dem Ereignishorizont des Schwarzen Lochs und der Umwelt, oder sie sind Effekte, die von der das Schwarze Loch umgebenden Raumzeit ausgehen, nicht jedoch vom Schwarzen Loch selbst. Wie es dazu kommt, lässt sich mit den bestehenden Theorien nicht verständlich machen.

3. Es gibt Schwarze Löcher, aber - so die verrückteste der denkbaren Varianten - sie haben nach aussen hin keine gravitative und keine elektromagnetische Wirkung. Dann haben Schwarze Löcher - im Gegensatz zum Bild, welches die Allgemeine Relativitätstheorie von ihnen liefert - keine (durch Wirkungen bemerkbare) Masse und Ladung. Mit dem Eindringen von masse- oder ladungsbehafteten Objekten in den Ereignishorizont des Schwarzen Loches würden sie komplett aus unserem Universum verschwinden. Schwarze Löcher würden dann aber auch keine masse- oder ladungsbehafteten Objekte mehr aus ihrem Umfeld anziehen. Ihre Ereignishorizonte würden vielmehr Raumregionen auszeichnen, in denen Dinge, die man hineinwirft, völlig spurlos verschwinden. 
Schwarze Löcher, wenn man die quantenfeldtheoretischen Eigenschaften des Vakuums in der Nähe ihres Ereignishorizontes berücksichtigt, nicht völlig schwarz sein können, sondern Strahlung absondern müssten.

"The intense gravitational field near the black hole causes the creation of pairs of particles and antiparticles, one of which falls into the black hole and the other of which escapes to infinity. The particle that escapes appears to have been emitted by the black hole." (Hawking (1980) 19f)

Mit dieser "Hawking-Strahlung" Schwarzer Löcher, die aufgrund der zu erwartenden Eigenschaften des quantenfeldtheoretischen Vakuums und aufgrund der Tatsache, dass es völlig zufällig ist, welches virtuelle Teilchen nun ins Schwarze Loch fällt, bestenfalls statistisch vorhersagbar und thermodynamisch charakterisierbar ist, geht jedoch eine Unvorhersagbarkeit einher, die noch die auf der Grundlage der Quantenmechanik und der Heisenbergschen Unschärfen gegebene Unvorhersagbarkeit übertrifft:

"An observer at a distance from the black hole can measure only the outgoing particles and he cannot correlate them with those that fell into the hole because he cannot observe them. This means that the outgoing particles have an extra degree of randomness or unpredictability over and above that usually associated with the Uncertainty Principle." (Hawking (1980) 19f)

Was aber noch viel gravierender ist, ist das mit der Hawking-Strahlung und der aus ihr resultierenden Unvorhersagbarkeit verbundene Informationsparadoxon Schwarzer Löcher: ${ }^{215}$ Bildet sich ein Schwarzes Loch etwa aus einem Materiesystem, das sich in einem reinen quantenmechanischen $\mathrm{Zu}$ stand befindet, so wird die vom Schwarzen Loch nach und nach abgestrahlte thermische Hawking-Strahlung kaum diesen reinen Zustand reproduzieren.

"If we imagine a matter system in a pure state which collapse to form a black hole, and if we consider the complete evaporation process assuming the radiation to be exactly thermal, at the end we are left with

$214 \quad$ Siehe Hawking (1974) und (1975).

215 Siehe Hawking (1976), (1982) und (2005) sowie Belot / Earman / Ruetsche (1999). 
a mixed state. In other words, although we know the initial state of the system we cannot predict what the final state would be. This clearly violates the laws of Quantum Mechanics." (Alvarez-Gaumé / Vázquez-Mozo (1992) 17)

Die Unitarität der Schrödinger-Gleichung wird offensichtlich durch Schwarze Löcher verletzt. Der mit den von der Allgemeinen Relativitätstheorie vorhergesagten Schwarzen Löchern einhergehende Informationsverlust ist mit der Quantenmechanik und ihrer unitären Dynamik völlig unverträglich. Der tatsächlich vorliegende Sachverhalt lässt sich mittels der bestehenden Theorien nicht erschliessen. Eine Theorie der Quantengravitation müsste - im Verbund mit empirischen Belegen - klären können, ob es wirklich zum Informationsparadoxon Schwarzer Löcher kommt.

Ebenso erst im Rahmen einer Theorie der Quantengravitation wird sich das Zustandekommen der von Jacob Bekenstein Anfang der siebziger Jahre postulierten Entropie Schwarzer Löcher klären lassen. ${ }^{216}$ Welche Mikrozustände diese finite, aber sehr grosse Entropie bestimmen, ist im Rahmen der bestehenden Theorien völlig unklar. Klärungen durch eine Theorie der Quantengravitation erhofft man sich zudem für die Fragen der Kosmologie und der Physik des frühen Universums: Wie hat die heutige Expansion des Universums begonnen? Wie entwickelt sich das Universum? Was ist das im Inflationären Szenario postulierte Inflatonfeld und wodurch kommt es zustande? ${ }^{217}$ Wie gross ist die kosmologische Konstante und wie kommt sie zustande? Warum liegt die quantenfeldtheoretische Berechnung der Vakuumenergiedichte um etwa 120 Zehnerpotenzen über dem empirisch

216 Eine Erörterung der Bekenstein-Hawking-Entropie folgt im Kap. 6.2., wenn es um die Probleme der Raumzeitkonzeption des Stringansatzes und die Perspektiven für die Konzeption der Raumzeit in der Quantengravitation gehen wird.

217 Siehe zum Inflationären Szenario etwa Linde (1984) und (1990) sowie Guth (2000). Das Inflatonfeld soll die Ursache einer inflationären Expansionsphase des Universums sein. Die Argumente für das Inflationäre Szenario beruhen vor allem auf der Homogenität und Isotropie der Hintergrundstrahlung. Diese ist ohne die Annahme einer inflationären Expansion nicht zu erklären, denn es hätte seit dem Urknall keinen kausalen Kontakt zwischen weit voneinander entfernten Regionen des beobachtbaren Universums gegeben, wenn diese nicht im Rahmen einer inflationären Expansion aus einem anfänglich sehr kleinen Raumbereich hervorgegangen sein sollten. Dies ist das Horizontproblem der Kosmologie. Auch die Flachheit der Raumzeit findet im Inflationären Szenario ihre Erklärung. 
erschliessbaren Wert? ${ }^{218}$ Eine Lösung dieser offenen Fragen könnte im Rahmen einer Theorie der Quantengravitation vielleicht erreichbar sein. Auf jeden Fall sollten sich jedoch die zwischen der Allgemeinen Relativitätstheorie und den Quantenfeldtheorien auftretenden Unverträglichkeiten im Rahmen einer solchen Theorie auflösen lassen.

\section{Motivationen für eine nomologische Vereinigung aller Wechselwirkungen}

Was spricht aber über eine konzeptionelle Vereinheitlichung hinaus für eine nomologische Vereinigung? Was legt über eine Theorie der Quantengravitation hinaus eine vereinheitlichte Theorie aller Wechselwirkungen als Ziel nahe? - Das deutlichste und konkreteste Argument dafür besteht in der sich mit den bestehenden Ansätzen und ihrer empirischen Fundierung abzeichnenden Konvergenz der energieabhängigen effektiven Kopplungskonstanten der Quantenfeldtheorien kurz vor der Planck-Ebene, gemeinsam mit der effektiven Kopplungskonstante der Gravitation. ${ }^{219}$

218 Träfen die quantenfeldtheoretischen Abschätzungen zur kosmologischen Konstante (bzw. Vakuumenergiedichte) zu, so müssten die Galaxien durch die resultierende abstossende Wirkung auseinanderfliegen und der Kosmos müsste eine immense Raumkrümmung mit Krümmungsradien im Meterbereich aufweisen, was die Existenz von Galaxien, aber auch die von Beobachtern, von vornherein ausschliesst. Diese massive Abweichung zwischen theoretischen Berechnungen und empirischen Befunden ist als "Problem der Kosmologischen Konstante" bekannt. Siehe Weinberg (1989). Die kosmologische Konstante liegt nach den neuesten Messungen der Beschleunigung der Expansion des Kosmos etwa in der Grössenordnung der Materiedichte im Universum. Vgl. auch Kap. 5.

219 Als Grundlage für eine Theorie, welche die nomologische Vereinigung aller Wechselwirkungen realisiert, die sich in der Konvergenz der effektiven Kopplungskonstanten abzeichnet, bietet sich erst einmal die Wahl einer Symmetriegruppe an, welche die Symmetriegruppen der bekannten Wechselwirkungen als Untergruppen umfasst und so deren Zustandekommen im Rahmen spontaner Symmetriebrechungen verständlich machen könnte. Eine ausreichend grosse und angemessen ausgewählte Eichsymmetriegruppe ist zudem nach den bestehenden Erfahrungen wohl der beste Weg, die in den bisherigen quantenfeldtheoretischen Ansätzen auftretenden Divergenzen zu beseitigen. Wählt man jedoch eine zu grosse Symmetriegruppe, so sind Bosonen mit Spin 3 oder mehr die Folge. Dies führt wiederum zu Inkonsistenzen.

"[...] an interacting spin-3 theory is probably not consistent." (Kaku (1999) 12) 
Da die unmittelbare Quantisierung der Gravitation im Sinne der Quantenfeldtheorien bisher immer mit dem Problem der Nicht-Renormierbarkeit zu kämpfen hatte und offensichtlich auch keine Aussicht auf eine Lösung dieses Problems besteht, solange man sich ausschliesslich auf die Gravitation bezieht, kommt als weitere Motivation für eine nomologische Vereinigung die Annahme hinzu, dass sich die Gravitation vielleicht nur gemeinsam mit allen anderen Wechselwirkungen adäquat beschreiben lässt, so wie sich schon die schwache Wechselwirkung, wie das Glashow-Salam-WeinbergModell zeigte, nur gemeinsam mit der elektromagnetischen Wechselwirkung in einem konsistenten, renormierbaren Ansatz erfassen liess. Vielleicht, so die weitergehende Hoffnung, hebt eine Einbeziehung der Gravitation sogar die Divergenzen, die eine Renormierung erforderlich machen, gänzlich auf. Dies würde problematische Renormierungsverfahren obsolet werden lassen, so dass die Parameter der resultierenden Theorie nicht mehr experimentell bestimmt werden müssen, sondern von der Theorie vorhergesagt werden können. Dies zeichnet sich für den Stringansatz zumindest schon ab.

Die Divergenzfreiheit ist jedoch, wie zuvor schon erwähnt, ${ }^{220}$ eigentlich nicht nur eine Hoffnung, sondern vielmehr die einzige Chance für eine Einbindung der Gravitation in eine vereinheitlichte Theorie aller Wechselwirkungen: Denn eine Theorie der Quantengravitation ist, wie sich zeigen lässt, notwendigerweise entweder finit oder nicht-renormierbar. Also ist die angestrebte vereinheitlichte Theorie aller Wechselwirkungen entweder eine finite Theorie, die keiner Renormierung bedarf, oder die eventuell auftretenden Divergenzen sind ohnehin nicht-renormierbarer Natur, so dass die Theorie ohne deskriptiven oder prognostizistischen Nutzen wäre.

Neben den Indizien, die für eine nomologische Vereinheitlichung sprechen, gibt es eine ganze Reihe offener Fragen und offener Probleme des quantenfeldtheoretischen Standardmodells, deren Klärung man sich innerhalb einer abschliessenden vereinheitlichten Theorie aller Wechselwirkun-

Möglicherweise, so die Annahme, gibt es also nur wenige Theorien, die in der Lage sind, störungstheoretische Divergenzen und gleichzeitig Bosonen mit höherem Spin als 2 zu vermeiden (und die zudem die Symmetrien des Standardmodells als Untergruppen ihrer Symmetrien enthalten).

220 Vgl. Kap. 2.1. 
gen erhofft. ${ }^{221}$ Hierbei könnte man etwa an eine Erklärung für die Zahl der Teilchenfamilien denken. Ein anderer wichtiger Punkt betrifft die vielen freien Parameter des Standardmodells. Da eine vereinheitlichte Theorie, wenn sie überhaupt formulierbar sein sollte, notwendigerweise finit ist und keiner Renormierung bedarf, wären ihre Parameter nicht mehr experimentell zu bestimmen, sondern würden von der Theorie vorhergesagt werden. Damit wäre einerseits die Vielzahl freier Parameter, wie sie das Standardmodell auszeichnen, vermeidbar, andererseits wäre zu hoffen, dass die Parameter des Standardmodells von einer solchen Theorie in ihrem Zustandekommen erklärbar werden.

\section{Die Vorteile der Supersymmetrie}

Der Stringansatz bemüht sich, im Gegensatz zum Standardmodell, mit welchem nur eine konzeptionelle Vereinheitlichung erreicht wird, um eine nomologische Vereinigung. Hierbei spielt die Supersymmetrie eine entscheidende Rolle. Denn der Stringansatz ist ohne die Supersymmetrie gar nicht denkbar; ohne sie können die Stringtheorien nicht konsistent formuliert werden. Das ist aber kein Nachteil, sondern stellt sich bei genauerer Betrachtung als ein erheblicher Vorteil heraus. Denn - unabhängig von modelltheoretisch-formalen und innertheoretischen Überlegungen - verleiht die Supersymmetrie aufgrund der mit ihr einhergehenden strukturellen und phänomenologischen Implikationen sowohl dem Stringansatz als auch dem nomologischen Vereinheitlichungsprogramm einen erheblichen Plausibilitätsgewinn.

Die Supersymmetrie ist vordergründig eine Symmetrierelation hinsichtlich der Vertauschung von Bosonen und Fermionen. Sie hebt den Unterschied zwischen den Zuständen der fermionischen Materiefelder und den Zuständen der bosonischen Wechselwirkungseichfelder, wie er für Eichtheorien charakteristisch ist, auf. Mit der Supersymmetrie bietet sich aber vor allem eine einzigartige Verbindung zwischen den durch Eichfelder beschriebenen Wechselwirkungen des quantenfeldtheoretischen Standardmodells und der

221 Die verschiedenen offenen Probleme des Standardmodells, deren Klärung man sich im Rahmen einer vereinheitlichten Theorie erhofft, werden in Kap. 4.4. zu diskutieren sein. 
im geometrodynamisch ausgerichteten Ansatz der Allgemeinen Relativitätstheorie vorliegenden Beschreibung der Gravitation. Denn die Supersymmetrie verbindet raumzeitliche mit internen Invarianzen. Interne Symmetrien sind solche, die Felder an Raumzeitpunkten betreffen. $\mathrm{Zu}$ ihnen zählen insbesondere die Eichsymmetrien der Quantenfeldtheorien, die darin zum Ausdruck kommen, dass die mit den entsprechenden bosonischen Wechselwirkungseichfeldern gekoppelten Fermionenfelder der Materie hinsichtlich ihrer Lagrange-Dichte gegenüber lokalen Phasentransformationen invariant bleiben. Raumzeit-Symmetrien hingegen sind solche, welche die Translation von Feldern zwischen Raumzeitpunkten bewirken. Das wichtigste Beispiel ist die Poincaré-Invarianz, die als Invarianz-Gruppe der flachen Metrik Translationen und Lorentz-Transformationen umfasst. Die Supersymmetrie, erst einmal als Invarianz der Vertauschung von Bosonen und Fermionen, also als interne Symmetrie, formuliert, stellt sich nun ebenso als raumzeitliche Invarianz heraus. Sie ist mit der raumzeitlichen Translationsinvarianz in der Weise verbunden, dass zwei Supersymmetrie-Transformationen (Rotationen im Supersymmetrieraum) eine raumzeitliche Translationsbewegung ergeben, also einer Poincaré-Transformation entsprechen. Die Supersymmetrie ist die einzig bekannte Erweiterung der Poincaré-Gruppe.

"Initially interest in this concept was motivated mainly by the abstract mathematical question whether any generalisation of the classical symmetry groups was possible. It turned out that supersymmetry is the maximal consistent solution in this respect. Soon after the construction of the first supersymmetric toy model it became clear that a formulation of supersymmetry as a gauge-symmetry (= local supersymmetry or supergravity) had an exciting potential to provide a fuller understanding of the particle character of gravity." (Dawid (2004) 7)

Damit ist die Verbindung der Supersymmetrie mit der Gravitation naheliegend:

"Lastly, when supersymmetry is elevated into a local gauge theory, it naturally reduces the divergences of quantum gravity. This is because local supersymmetry can be defined only in the presence of gravitons [...]. Local supersymmetry is thus intimately tied up with general relativity." (Kaku (1999) 102) 
Die Supersymmetrie bietet die beste Möglichkeit einer Verbindung zwischen den Eichsymmetrien der Quantenfeldtheorien und der PoincaréInvarianz. Dies ist neben der durch sie erreichten Lösung des Tachyonenund des Chiralitätsproblems der alten bosonischen Stringtheorie ein wichtiges Motivationselement für die Einbeziehung der Supersymmetrie in den Stringansatz. Zudem scheint gerade die Supersymmetrie die Ursache dafür zu sein, dass aufgrund der Vorzeichen der entsprechenden Beiträge die divergenten, nicht-renormierbaren Beiträge der Gravitonenwechselwirkung durch hinzukommende fermionische Anteile aufgehoben werden.

"Supersymmetry generates super-Ward-Takahashi identities that cancel many normally divergent Feynman graphs." (Kaku (1999) 101)

Vor allem aber: Die schon oben als Argument für eine nomologische Vereinigung angeführte, annähernde Konvergenz der effektiven energieabhängigen Kopplungskonstanten der bekannten Quantenfeldtheorien kurz vor der Planck-Ebene, wird erst unter Berücksichtigung der Supersymmetrie gemeinsam mit der supersymmetrisch korrigierten effektiven Kopplungskonstante der Gravitation - zu einer, wie es aussieht, exakten Konvergenz. Dies ist einerseits ein weiterer deutlicher Hinweis auf die Relevanz der Supersymmetrie. Es legt nahe, dass eine fundamentale Theorie, so sie sich formulieren lassen sollte, wahrscheinlich supersymmetrisch sein wird. Damit führt die Einbeziehung der Supersymmetrie zu einem weiteren, von der Theorieentwicklung des Stringansatzes unabhängigen Argument dafür, den Stringansatz als Anwärter für eine nomologische Vereinigung ernst zu nehmen. Andererseits stützt die Konvergenz der supersymmetrisch korrigierten Kopplungskonstanten aber insbesondere auch die Motivationslage für das nomologische Vereinheitlichungsprogramm. Dass die Kopplungsparameter für alle Wechselwirkungen unter bestimmten energetischen Bedingungen identisch werden, ist eines der wesentlichen Kennzeichen einer erfolgreichen vereinheitlichten Beschreibung. ${ }^{222}$ Darüberhinaus liefert die supersymmetrisch korrigierte Konvergenz der effektiven Kopplungskonstanten einen weiteren Hinweis dafür, dass die Stringdynamik sich, wenn sie zu einer nomologischen Vereinigung führen soll, auf der Planck-Ebene abspielen muss. Möglicherweise aufkommender Enthusiasmus wird allerdings ein wenig dadurch gebremst, dass die Aufstellung einer Theorie, deren Dynamik sich auf der Planck-Ebene abspielt, hinsichtlich unserer bestehenden Theorien und hinsichtlich der verfügbaren empirischen Daten 
eine gewagte Extrapolation über 16 bis 18 Zehnerpotenzen hinweg darstellt.

"It is presumptuous to assume that there will be no surprises in the 'desert' between 100 and $10^{19} \mathrm{GeV}$. New, totally unexpected phenomena have always cropped up when we have pushed the energy scale of our accelerators. Superstring theory, however, makes predictions over the next 17 orders of magnitude, which is unheard of in the history of science." (Kaku (1999) 17)

Und empirische Anzeichen für die Supersymmetrie liegen, trotz ihrer immensen konzeptionellen Vorteile, in keiner Weise vor.

"Supersymmetry is one of the most elegant of all symmetries [...] However, the irony is that there is not a single shred of experimental evidence in its favor." (Kaku (1999) 101)

Solange aber keine empirischen Anzeichen für die Supersymmetrie vorliegen, bleibt unklar, ob sie in der Natur wirklich realisiert ist. Daran ändert auch die Tatsache nichts, dass sie eine ideale Verbindung aus internen und externen, raumzeitlichen Symmetrien darstellt und damit auf die Gravitation hinweist, dass ihre Einbeziehung zur Konvergenz der Kopplungskonstanten führt, und dass sie die Hoffnung schürt, dass die perturbativen Entwicklungen möglicherweise, was immer noch nicht definitiv nachgewiesen ist, finit bleiben und die Theorie erst gar keiner Renormierung bedarf. Denn konzeptionelle Vorteile allein sind letztendlich nicht ausschlaggebend für die Frage, ob eine bestimmte Eigenschaft der Natur tatsächlich zukommt. Hierüber entscheidet, wenn überhaupt, die Empirie. 


\subsection{Das Problem der empirischen Kontrolle}

Der Stringansatz verfügt, genauso wie alle anderen Ansätze zu einer Quantengravitationstheorie, über keine empirischen Bestätigungen:

"So far, no approach to quantum gravity can claim even a single piece of experimental evidence." (Rovelli (1998) 2)

Aber das Problem des Stringansatzes besteht nicht einfach darin, dass er noch keine empirischen Bestätigungen aufweisen kann, diese aber für die Zukunft zu erwarten wären, vielleicht bei verbesserter experimenteller Ausstattung. Das Problem besteht vielmehr darin, dass es nicht die geringsten quantitativen, grundsätzlich (vielleicht bei Weiterentwicklung der experimentellen Technik) empirisch testbaren Vorhersagen gibt, noch eine vielversprechende Idee, wie man zu solchen empirisch überprüfbaren Resultaten gelangen könnte.

"The experimental situation is best described with Pauli's phrase 'it's not even wrong'. [...] String theory not only makes no predictions about physical phenomena at experimentally accessible energies, it makes no predictions whatsoever." (Woit (2001) 2)

Damit wird das Problem mit der Empirie letztlich vor allem zu einem konzeptionellen Problem:

"[...] the fundamental problem facing superstrings is not necessarily an experimental one. It is mainly theoretical. The outstanding problem of the theory is to calculate dynamical symmetry breaking, so that its predictions can be compared with experimental data at ordinary energies. I A fundamental theory at Planck energies is also a fundamental theory at ordinary energies. Thus, the main stumbling block to the development of the theory is an understanding of its nonperturbative behavior." (Kaku (1999) 18)

Was sind aber die Ursachen dafür? 


\section{Die Ursachen}

Der Stringansatz, wie er sich zur Zeit darstellt, ist in grundlegender Hinsicht unvollständig. Es handelt sich, wie schon verdeutlicht, nicht im strengen Sinne um eine physikalische Theorie, sondern um eine Vielzahl von mathematisch anformulierten Ideen und Ansätzen zu einer vielleicht in Entstehung befindlichen Theorie. Die gesamte Entwicklung der Superstringtheorien erfolgte, was auch führende Stringtheoretiker unumwunden zugestehen, bisher auf der Grundlage konzeptioneller Anforderungen und Ideen - und nicht etwa auf der empirischer Randbedingungen. ${ }^{223}$

"[...] with absolutely no experimental basis, string theorists constructed a monumental mathematical edifice." (Susskind (2005) 270)

Dass sich aus dem Stringansatz keine quantitativen Vorhersagen ableiten lassen, hängt vorrangig mit mehreren konzeptionellen Problemen zusammen, die noch keine Lösung erfahren haben:

So ist es insbesondere bisher nicht klar, wie - und vor allem wieso - man von den aus internen Konsistenzgründen (Gewährleistung der Anomaliefreiheit, der Unitarität und der Lorentz-Invarianz) postulierten zehn Dimensionen der Superstringtheorien zu den vier Dimensionen der phänomenologischen Raumzeit kommt. Grundsätzlich gibt es, wie erwähnt, wohl zwei Möglichkeiten: zum einen die mikroskopische Kompaktifizierung der überzähligen Dimensionen auf der Planck-Ebene, ${ }^{224}$ zum anderen die Anbindung der Materie an Dirichlet-Brane. ${ }^{225}$ Vielleicht kommt aber auch eine Kombination beider Varianten in Frage. ${ }^{226}$

Für die erste Variante stellt sich das Problem folgendermassen dar: Die Modalitäten der Zusammenfaltung der kompaktifizierten, überzähligen Raumdimensionen sind unbekannt, ebenso wie die möglichen Gründe für eine solche Zusammenfaltung bzw. für den nicht-kompakten Zustand der phänomenologischen Raumzeit. Es kommt für die Kompaktifizierung

223 Siehe Kap. 4.1. und 4.2.

224 Siehe Kap. 2.2.

225 Siehe Kap. 2.4.

226 Siehe Kap. 2.4. 
grundsätzlich eine sehr grosse Zahl von (sechsdimensionalen) Calabi-YauRäumen mit zum Teil sehr komplexer Topologie in Frage. Diese mathematisch unterschiedlichen und schliesslich physikalisch zu interpretierenden Kompaktifizierungsmodi führen jedoch, soweit man dies heute abschätzen kann, im allgemeinen zu grundlegend verschiedenen physikalischen Resultaten. Sie beschreiben völlig verschiedene Welten mit unterschiedlichen Teilchenspektren und unterschiedlicher Kosmologie. Die für die Superstringtheorien erhofften Ergebnisse - etwa bezüglich der Zahl und der Beschaffenheit der zu erwartenden Elementarteilchen, der zu erwartenden Teilchenfamilien ${ }^{227}$ sowie schliesslich der jeweiligen Teilchenmassen hängen ganz entscheidend vom jeweiligen Kompaktifizierungsmodus ab, dessen Festlegung durch die Theorie zur Zeit erst einmal vollkommen unklar erscheint. Und es geht, wie schon angedeutet, nicht etwa um drei oder fünf Alternativen, die man durchrechnen könnte.

"Despite all the progress in gauge theories, quantum gravity, string theory etc. not one of these problems have been solved. Not one mass or coupling constant of any particle considered now to be elementary has ever been explained by fundamental theory." (Smolin (2004) 7)

Ein anderes grundlegendes konzeptionelles Problem des Stringansatzes, das quantitative Vorhersagen bisher verhindert hat, besteht darin, dass die von ihm angestrebten nicht-perturbativen Grundgleichungen, die gleichermassen die Dynamik der basalen schwingungsfähigen Konstituenten wie auch die Dynamik der Raumzeitstrukturen und -topologien beschreiben sollten, bisher schlichtweg unbekannt sind. ${ }^{228}$ Es gibt nicht einmal eine Vorstellung davon, welche fundamentalen Prinzipien den bisher bekann-

227 Eines der bisher nur wenigen analytischen Ergebnisse besteht im Nachweis einer Korrelation zwischen den zu erwartenden Teilchenfamilien bzw. -generationen und den Löchern innerhalb der Topologie der kompakten Calabi-Yau-Räume. Vgl. Kap. 2.2. Die Zahl der Teilchengenerationen ist gleich dem halben Absolutbetrag der Euler-Zahl des kompakten Raumes. Aber zum einen ist eben der Kompaktifizierungsmodus und mithin die zu erwartende Topologie noch völlig unklar. Zum anderen wäre auch eine korrekte Vorhersage (bzw. Nachhersage) der drei bekannten Teilchengenerationen durch die Superstringtheorien, wenn diese sich auf einen eindeutigen Kompaktifizierungsmodus festlegen liessen, viel zu unspezifisch, um als reliabler experimenteller Nachweis herhalten zu können. Es könnte grundsätzlich ganz andere Theorien geben, die zu diesem Ergebnis kommen.

228 Siehe v.a. Kap. 2.3. 
ten, ausschliesslich perturbativen Prozeduren zugrundeliegen könnten. ${ }^{229}$ Und das nach über dreissig Jahren Entwicklung im Stringansatz!

Zudem sind die beiden geschilderten Probleme nicht voneinander unabhängig. Das Problem der immer noch unbekannten nicht-perturbativen Dynamik hängt konzeptionell mit dem Kompaktifizierungsproblem und dem Problem der intendierten Ableitung der niederenergetischen Dynamik für die Vierer-Raumzeit zusammen:

"The problem, however, is that dimensional breaking from a 10-dimensional theory down to four dimensions can occur only nonperturbatively. To any finite order in the perturbation theory, the dimension of space-time seems perfectly stable. [...] Unfortunately, we do not yet understand how to perform realistic nonperturbative calculations in string theory [...]. Thus, physicists have not been able to calculate the stability of any classical vacuum solution." (Kaku (1999) 337)

Manche Theoretiker, wie etwa Edward Witten, vermuten, dass wir vielleicht noch nicht einmal über die geeigneten mathematischen Instrumentarien verfügen, um diese für die Theorie vorauseilend in ihrer Existenz postulierten Grundgleichungen überhaupt zu formulieren. ${ }^{230}$ Manchmal war sogar die Rede von der Mathematik des einundzwanzigsten Jahrhunderts, die im Stringansatz schon im zwanzigsten zum Einsatz kommt. Dies klang jedoch im zwanzigsten Jahrhundert wesentlich besser, als es heute klingen mag, wie etwa Lee Smolin bemerkt:

"The story of string theory is not easy to tell, because even now we do not really know what string theory is. We know a great deal about it, enough to know that it is something really marvellous. We know much about how to carry out certain kinds of calculations in string theory. Those calculations suggest that, at the very least, string theory may be part of the ultimate quantum theory of gravity. But we do not have a good definition of it, nor do we know what its fundamental principles are. (It used to be said that string theory was part of twenty-first century mathematics that had fallen by luck into our hands in the twentieth century. This does not sound quite as good now as it used to.) The problem is that we do not yet have string theory expressed in any

229 Siehe Kap. 2.3. und 4.1.

230 Vgl. das Interview mit Witten in Davies / Brown (1992). 
form that could be that of a fundamental theory. What we have on paper cannot be considered to be the theory itself. What we have is no more than a long list of examples of solutions of the theory; what we do not yet have is the theory they are solutions of. It is as if we had a long list of solutions to the Einstein equations, without knowing the basic principles of general relativity or having any way to write down the actual equation that defines the theory. / Or, to take a simpler example, string theory in its present form most likely has the same relationsship to its ultimate form as Kepler's astronomy had to Newton's physics." (Smolin (2000) 149f)

Dennoch sprechen manche Stringtheoretiker mutig von ihrem Ansatz als einer "Theory of Everything". Bisher existiert aber, von ganz wenigen tentativen Vorstössen in den nicht-perturbativen Bereich (supersymmetrische BPS-Zustände) ${ }^{231}$ abgesehen, im wesentlichen nur ein perturbativer Ansatz, für den lediglich die ersten störungstheoretischen Glieder berücksichtigt wurden.

"[...] after many years there are only proofs of consistency and finiteness of perturbative string theory to second non-trivial order in perturbation theory, and attempts to go further have not so far succeeded." (Smolin (2004) 10)

Und die zur Zeit verwendeten störungstheoretischen Ansätze und Methoden sind weit entfernt von der Möglichkeit der Ableitbarkeit von testbaren Resultaten, was sogar führende Stringtheoretiker unumwunden zugeben:

"The approximate equations that string theorists currently use are not powerful enough to work out the resulting physics fully for any choice of Calabi-Yau shape. [...] precise and definitive physical conclusions, such as the mass of the electron or the strength of the weak force, require equations that are far more exact than the present approximate framework. [...] the 'natural' energy scale of string theory is the Planck energy, and it is only through extremely delicate cancellations that string theory yields vibrational patterns with masses in the vicinity of those of the known matter and force particles." (Greene (1999) 220)

$231 \quad$ Siehe Kap. 2.3. 
Aber auch wenn alle konzeptionellen Probleme des Stringansatzes gelöst wären, bestände immer noch die Schwierigkeit, dass dieser eine Dynamik erfassen soll, die sich nach heutigem Ermessen eben auf der Planck-Ebene abspielt. Zwischen dem Energiebereich, dessen Dynamik die Theorie beschreiben soll, und dem, der unseren Experimenten zur Zeit zugänglich ist, liegen damit mindestens sechzehn Zehnerpotenzen. Und daran wird sich vielleicht auch nie etwas Entscheidendes ändern - ausser, es sollte sich überraschenderweise herausstellen, dass die Vereinigung der Wechselwirkungskräfte nicht auf der Planck-Ebene stattfindet, sondern in einem wesentlich niedrigeren Energiebereich. ${ }^{232}$ Ist dem nicht so, so müssten wir, um uns den Energiebereich, auf den sich die Superstringtheorien originär beziehen, experimentell zugänglich zu machen, so etwas wie einen künstlichen Urknall erzeugen.

"It is impossible experimentally to reach the tremendous energies found at the Planck scale. Therefore, the theory is in some sense untestable. A theory that is untestable is not an acceptable physical theory." (Kaku (1999) 17)

\section{Das Problem der empirischen Kontrolle}

Eigentlich ist es auch für die Vertreter des Stringansatzes unkontrovers, für empirisch-wissenschaftliche Theorien eine Ankopplung an die Empirie zu fordern. Eine Theorie ohne eine solche empirische Ankopplung ist eigentlich keine empirisch-wissenschaftliche Theorie, auch wenn sie sich aus einer Tradition empirisch-wissenschaftlicher Theorien ableitet:

"Unless we can make contact with the known empirical data, then the theory, no matter how elegant, must be discarded." (Kaku (1999) 337)

Insofern ist es nicht erstaunlich, wenn einige Stimmen für die Untragbarkeit des Stringansatzes votieren. Erstaunlicher ist es hingegen, dass angesichts des Mangels an empirischen Überprüfungsmöglichkeiten interne Konsistenztests nicht nur immer mehr an Bedeutung für den Stringansatz 
gewannen, sondern manchmal geradezu als Ersatz für die mangelnde empirische Ankopplung gehandelt werden:

"Clearly, all what we can do for the foreseeable future to test these ideas are consistency checks. Such checks can be highly non-trivial, from a formal as well as from a physical point of view." (Lerche (2000) 30)

Diese Strategie hat ihre Verankerung in der Idee der Einzigartigkeit und Eindeutigkeit des Stringansatzes, die im nächsten Kapitel zu erörtern sein wird. ${ }^{233}$ Aber auch wenn diese Idee nicht an den tatsächlichen innertheoretischen Gegebenheiten gescheitert wäre, ${ }^{234}$ so würde sie ohnehin eine empirische Überprüfung der Theorie nicht ersetzen. Die Gründe dafür lassen sich in zwei fiktiven Problemszenarien fokussieren:

1. Nehmen wir an, es gäbe eine erwiesenermassen konsistente Theorie der Quantengravitation, auf die sich zwar über die konzeptionellen Randbedingungen ihrer Entstehung die empirischen Randbedingungen ihrer Vorläufertheorien indirekt und partiell übertragen hätten, die aber keine eigenen, unabhängigen empirischen Überprüfungsinstanzen aufwiese. - Diese Theorie könnte dann zwar vielleicht als konzeptionelles, mathematisches Konstrukt betrachtet werden, in dem die vorliegenden konzeptionellen Unverträglichkeiten ihrer Vorgängertheorien überwunden würden. Sie wäre insofern eine konsistente strukturelle Weiterspinnung dieser Vorgängertheorien. Aber es liesse sich kaum für eine realistische Deutbarkeit der von ihr postulierten Szenarien und Entitäten plädieren. Diese Theorie müsste nicht unbedingt unsere Welt beschreiben. Es könnte immer noch andere konsistente Theorien geben, welche die gleiche konzeptionelle Leistung im Hinblick auf die Vorgängertheorien und die in sie eingeflossene Empirie erbringen.

2. Nehmen wir nun an, die Existenz anderer Theorien, welche die gleiche Leistung im Hinblick auf die Vorgängertheorien und die in sie eingeflossene Empirie erbrächten, liesse sich, wie auch immer, ausschliessen. Es gäbe also mithin eine eindeutige, einzigartige konsistente Theorie der Quantengravitation, auf die sich über die konzep-

Siehe Kap. 5.1. und 5.2.

Siehe Kap. 5.2. 
tionellen Randbedingungen ihrer Entstehung die empirischen Randbedingungen ihrer Vorläufertheorien indirekt übertragen hätten. Aber auch diese Theorie wiese keine eigenen, unabhängigen empirischen Überprüfungsinstanzen auf. - Was würde sich gegenüber dem ersten Szenario ändern? Nur wenig: Die Theorie müsste zwar als das einzige konzeptionelle, mathematische Konstrukt betrachtet werden, in dem die konzeptionellen Unverträglichkeiten ihrer Vorgängertheorie überwunden würden. Sie wäre in dieser Hinsicht die einzige konsistente strukturelle Weiterspinnung dieser Vorgängertheorien. Aber es liesse sich damit immer noch nicht für die realistische Deutbarkeit der von ihr postulierten Szenarien und Entitäten plädieren. Die Theorie müsste nicht notwendigerweise unsere Welt beschreiben. Denn auch die nachweislich einzig mögliche konzeptionelle Weiterspinnung bestehender Theorien muss noch kein Gegenstück in der Realität aufweisen. Wir könnten es mit einer Patchwork-Welt ${ }^{235}$ zu tun haben, einem irreduziblen Flickenteppich der Phänomenbereiche. Wir könnten dann zwar vielleicht auf der Seite unserer theoretischen Beschreibungsansätze mutwillig konzeptionell vereinheitlichen. Das Ergebnis dieser konzeptionellen Vereinheitlichung müsste aber nicht notwendigerweise ein Gegenstück in der Realität aufweisen, weil diese sich vielleicht bestenfalls im Rahmen eines ganzen Arsenals von jeweils streckenweise mehr oder weniger adäquaten effektiven Theorien erfassen liesse, deren Wert sich im Rahmen einer jeweils engen empirischen Ankopplung ergäbe und nicht etwa auf der Grundlage irgendwelcher metaphysischer Überzeugungen.

Ein in der Welt vorzufindendes Gegenstück unserer theoretischen Bemühungen im Rahmen des Vereinheitlichungsprogramms müsste schon über unabhängige empirische Belege motiviert werden. Auch dann liesse sich zwar das Patchwork-Szenario immer noch nicht gänzlich ausschliessen, aber es würde sich damit zumindest als unplausibler erweisen. Jede weitere empirische Stützung würde diese Unplausibilität steigern und die Resultate der Vereinheitlichungsstrategie an Glaubwürdigkeit gewinnen lassen.

Ohne empirische Kontrolle kommt also nicht einmal eine einzigartige Theorie, eine als fundamental postulierte, letztgültige Realisierung des Vereinheitlichungsprogramms, aus. Auf innertheoretische Konsistenz alleine kann man sich ganz sicher nicht verlassen. Dies ist nicht erst nur vor

$235 \quad$ Siehe etwa Cartwright (1994), (1999) sowie (1983) und (1989). 
dem Hintergrund der Bedrohung durch das Patchwork-Szenario, sondern vor allem deshalb schon nicht ratsam, weil das Problem der Interpretation der Theorieaussagen hin auf ihre Korrelate in der Natur ohne empirische Ankopplung vollständig ausser Kontrolle gerät.

"When we look around us we do not observe the laws of nature; rather, we see the outcomes of those laws." (Barrow (1995) 44)

Für die Superstringtheorien etwa, wie sie sich heute darstellen, bleibt weitgehend unklar, welche ihrer theoretischen Aussagen und welche ihrer Implikationen - wenn überhaupt - wir in realistischer Weise als Beschreibung von tatsächlichen Tatbeständen interpretieren sollen und welche eben nicht. ${ }^{236}$ Beschreibt die Theorie tatsächliche Strukturen der Welt, genügt sie also den originären deskriptiven Anliegen physikalischer Naturbeschreibung, oder erfasst sie mathematische oder kognitive Substrukturen, aus denen sich zwar vielleicht partiell zutreffende Aussagen über die Wirklichkeit gewinnen lassen, die aber selbst - nicht zuletzt auch im Hinblick auf die innerhalb dieser Substrukturen postulierten Entitäten - über kein Korrelat in der Natur verfügen? Oder stellen die Superstringtheorien eine noch ungeklärte Mischung aus diesen beiden Möglichkeiten dar? Wenn ja, welche Aussagen gehören dann zur realistischen und welche zur instrumentalistischen Seite? Wie weit handelt es sich also tatsächlich noch um Physik?

"String theory began as a search for a conjectured unique theory that would unify all of nature. [...] To realize this hope, string theory relies on several mathematical conjectures which remain unproven, in spite of intense effort, and several physical hypotheses, which may turn out to be right or wrong. While the idea of duality, that gauge and other degrees of freedom may be described in terms of stringlike excitation, is attractive, the cost of realizing it as a fundamental, rather than an effective theory, appears high. Either there are or are not extra dimensions, and supersymmetry is either part of the laws of nature or not. In the end only experiment can tell, but there appears to be no near term experimental program which could falsify these hypotheses. What is so frustrating about string theory is that it could easily be wrong, in whole or in part, but there appear to be few realistic ways to find out." (Smolin (2003) 69)

$236 \quad$ Siehe Kap. 7. 


\section{Exotica als Chance?}

Solange es im wesentlichen nur perturbative Prozeduren in Stringansatz gibt und solange das Kompaktifizierungsproblem und die mit ihm auftretende Vieldeutigkeit der physikalischen Szenarien ${ }^{237}$ keine Lösung erfahren hat, wird sich an den Problemen mit der empirischen Überprüfbarkeit wahrscheinlich erst etwas ändern, wenn sich überraschende neue Bestätigungs- bzw. Falsifikationsinstanzen ergeben sollten, die zur Zeit noch nicht absehbar sind. So könnte es aussichtsreich sein, nach kosmologischen Implikationen der Superstringtheorien zu suchen, um hiermit schliesslich doch noch zu relevanten empirischen Daten zu gelangen. ${ }^{238}$ Eine andere Option besteht in der Hoffnung, dass sich spezifische Vorhersagen hinsichtlich völlig unerwarteter Teilchencharakteristika ergeben könnten. So gibt es im Stringansatz möglicherweise Szenarien, die Teilchen mit gebrochener Ladung zu Folge hätten:

"Thus there will be isolated fractional charges if there are twisted sectors [...]. In fact there must be such sectors. [...] The lightest fractionally charged particle must be stable due to charge conservation. The number of fractional charges in ordinary matter is known to be less than $10^{-20}$ per nucleon. If fractionally charged particles of mass $\mathrm{m}$ were in thermal equilibrium in the early universe at temperatures $T$ $>\mathrm{m}$, it is estimated that annihilation would only reduce their present abundance to approximately $10^{-9}$ per nucleon. Whether this is a problem depends critically on the masses of the fractionally charged states, whether all are near the string scale or whether some are near the weak scale. If all the fractional charges are superheavy then the situation is very similar to that with magnetic monopoles in grand

\footnotetext{
237

Siehe Kap. 5.

238 Siehe hierzu Kap. 2.4. Zu denken wäre vielleicht an Voraussagen der Superstringtheorien, die sich im Hinblick auf das Problem der Dunklen Materie und Dunklen Energie im Kosmos eindeutig interpretieren liessen. Hier sei etwa an das HoravaWitten-Szenario (Horava / Witten (1996), siehe auch Kolb / Seckel / Turner (1985)) mit seiner Schattenwelt erinnert, sowie an die Vorschläge von Lu, Huang, Fang und Zhang (2004), die dunkle Energie, die für die beschleunigte Expansion des Kosmos verantwortlich gemacht wird, als Effekt des Dilaton-Feldes darzustellen.
} 
unified theories. [...] It may also be the case that the universe was never hot enough to produce string-scale states thermally. Fractionally charged particles with masses near the weak scale are a potentially severe problem, unless they are charged under a new strongly coupled gauge symmetry and so confined." (Polchinski (2000a) $353)^{239}$

Bei solchen Szenarien und ihrer potentiellen empirischen Überprüfung wäre jedoch immer noch genau zu untersuchen, was eigentlich getestet wird: die Theorie selbst oder irgendwelche Konsequenzen, die auch mit völlig anderen konzeptionellen und theoretischen Kontexten vereinbar sein könnten.

\section{Die Alibi-Vorhersage}

Einige Stringtheoretiker kokettieren damit, dass ihr Ansatz immerhin eine eindeutige, empirisch bestätigbare Vorhersage macht, nämlich die der Existenz der Gravitation:

"Moreover, these theories have [...] the remarkable property of predicting gravity [...]." (Witten (1996) 25)

Diese sogenannte "Vorhersage", die bestenfalls als Nachhersage bezeichnet werden könnte, lässt sich jedoch nicht ernsthaft für den Stringansatz als empirische Bestätigung geltend machen. Denn es ist einzig und allein die Eigenschaft des Stringansatzes, die Gravitation in seine Beschreibung einzuschliessen und die Allgemeine Relativitätstheorie als Niederenergienäherung zu reproduzieren, die ihn überhaupt erst für die Physik interes-

239 Die Entdeckung magnetischer Monopole würde jedoch unter Umständen die Möglichkeit gebrochener elektrischer Ladungen eingrenzen:

"If unconfined fractional charges do exist, electric charge is quantized in a unit e/n smaller than the electron charge. The Dirac quantization condition implies that any magnetic monopole must have a magnetic charge which is an integer multiple of $2 \pi \mathrm{n} / e$. [...] Discovery of a monopole with charge $2 \pi / e$ would imply the nonexistence of fractional charges, and so have implications for string theory through the above theorems." (Polchinski (2000a) 355) 
sant macht und als mögliche Theorie der Quantengravitation ins Spiel bringt: ${ }^{240}$

"Claiming, as it is sometimes done, that a successful physical prediction of string theory is GR [general relativity] is a nonsense for various reasons. First, by the same token on could claim that the SU(5) grand unified theory (an extremely beautiful theoretical idea, sadly falsified by the proton decay experiments) is confirmed by the fact that it predicts electromagnetism. Second, GR did not emerge as a surprise from string theory: it is because string theory could describe gravity that is was taken seriously as a unified theory. Third, if GR was not known, nobody would have thought of replacing the flat spacetime metric in the string action with a curved and dynamical metric. 'Predicting' a spin-two particle is no big deal in a theory that predicts any sort of still unobserved other particles. The fact that string theory includes GR is a necessary condition for taking it seriously as a promising tentative theory of quantum gravity, not an argument in support of its physical correctness." (Rovelli (1998) 5)

Würde der Stringansatz nicht die Gravitation einschliessen, käme er überhaupt nicht als vereinheitlichte Theorie aller Wechselwirkungen einschliesslich der Quantengravitation in Frage. Der Einschluss der Gravitation ist das, was den Stringansatz überhaupt als relevant erscheinen lässt. Nur dann, wenn es davon völlig unabhängige Motivationen gäbe, und nur dann, wenn der entsprechende Ansatz schon über unabhängige empirische Bestätigungen verfügen würde, nur dann, wenn der Ansatz auch schon ohne dieses Indiz Existenzberechtigung besässe, liesse sich die "Vorhersage" der Gravitation als Argument für ihn ins Feld führen. Die "Vorhersage" der Gravitation könnte also bestenfalls für einen Ansatz, der seine Relevanz völlig anderen Zusammenhängen verdanken würde, die schon zu unabhängigen und schliesslich empirisch bestätigbaren Vorhersagen geführt hätten, als Kontrollinstanz ins Feld geführt werden. Wenn ein solcher Ansatz dann schliesslich auch noch überraschend zu einer weiteren Implikation - der Gravitation - führen würde, wäre dies ein interessantes Indiz, das zusätzlich für ihn spräche. Die vermeintliche "Vorhersage" der Gravitation durch den Stringansatz ist aber insbesondere ganz und gar nicht unabhängig von den bestehenden etablierten Theorien, die gerade vom Stringansatz zusammengeführt und letztlich als fundamentale physikali-

240 Siehe Kap. 4.1. und 4.2. 
sche Beschreibungen abgelöst werden sollen. Der Stringansatz reproduziert mit der Gravitation ein Phänomen, welches grundsätzlich schon von der Allgemeinen Relativitätstheorie beschrieben wird und sich bisher in dieser Beschreibung als empirisch adäquat erwiesen hat. Nur etwa eine empirische Bestätigung einer vom Stringansatz vorgenommenen Korrektur gegenüber der Allgemeinen Relativitätstheorie könnte hier eine Änderung bringen. Aber die zu erwartenden Stringkorrekturen zur Gravitation, wie sie von der Allgemeinen Relativitätstheorie beschrieben wird, lassen sich bisher genausowenig berechnen wie etwa die zu erwartenden Massen der supersymmetrischen Partnerteilchen oder auch einfach nur die Teilchenmassen des Standardmodells.

\section{Selbstimmunisierungstechniken}

Was passiert aber mit dem Stringansatz, wenn die empirische Kontrolle weiterhin ausbleibt? Wie gehen die Stringtheoretiker mit dem Ausbleiben empirischer Kontrollmöglichkeiten und folglich empirischer Bestätigungen um? Dies lässt sich an einer paradigmatischen Implikation des Stringansatzes verdeutlichen:

Die Superstringtheorien sagen, wie alle supersymmetrischen Theorien, Superpartner zu den uns bekannten Materieteilchen und Wechselwirkungsquanten voraus. Wie schon erwähnt, gibt es bisher aber nicht die geringsten empirischen Anzeichen für die Supersymmetrie. ${ }^{241}$

"Not one shred of experimental evidence has been found to confirm the existence of supersymmetry, let alone superstrings." (Kaku (1999) 17)

Dennoch erhofft man sich von der nächsten Beschleunigergeneration, insbesondere vom Large Hadron Collider bei CERN, einen Nachweis zumindest des leichtesten der supersymmetrischen Teilchen. Leider macht der Stringansatz jedoch keine quantitativen Vorhersagen hinsichtlich der zu erwartenden Massen dieser Teilchen. Sollten sich diese in Zukunft mit Hilfe von Beschleunigern nachweisen lassen, so wäre dies also noch nicht

$241 \quad$ Siehe Kap. 2.1., 4.1. und 4.2. 
notwendigerweise als eindeutige Bestätigung des Stringansatzes zu werten, sondern erst einmal nur als Bestätigung des Konzeptes der Supersymmetrie - und mithin aller supersymmetrischen Theorien. Etwas daran ändern könnte lediglich eine numerische Vorhersage der zu erwartenden Massen der supersymmetrischen Teilchen und ihr anschliessender experimenteller Nachweis. Aber von einer solchen numerischen Vorhersage sind die Stringtheorien weit entfernt.

Was passiert jedoch, wenn sich auch mit den neuen Beschleunigern keine supersymmetrischen Teilchen finden lassen? Würden die Stringtheoretiker ihren Ansatz dann aufgeben? - Offensichtlich nicht:

"So we are inclined to call supersymmetry a generic prediction. Suppose that the LHC rules this out. Will we still believe in this approach? I can only speak for myself, though I suspect that most others working in this field would agree. I believe that we have found the unique mathematical structure that consistently combines quantum mechanics and general relativity. So it must almost certainly be correct. For this reason, even though I do expect supersymmetry to be found, I would not abandon this theory if supersymmetry turns out to be absent." (Schwarz (1998) 2)

Die Strategie ist ziemlich einfach: Sollten die supersymmetrischen Partner der bekannten Elementarteilchen mit unseren technischen Mitteln auf absehbare Zeit nicht nachweisbar sein, so kann man, solange keine quantitativen Vorhersagen vorliegen, immer noch behaupten, dass sie dann eben eine höhere Masse haben müssen als die, welche mit unseren experimentellen Verfahren erreicht werden kann:

"[...] even if superpartner particles are not found by the Large Hadron Collider, this fact alone will not rule out string theory. since it might be that the superpartners are so heavy that they are beyond the reach of this machine as well." (Greene (1999) 222)

Eine solche Argumentationsweise ist natürlich für eine physikalische Theorie letztendlich nicht hinnehmbar. Sie entspricht geradezu einer Selbstimmunisierung der Theorie gegenüber fehlender empirischer Kontrolle. 
"Sal - So which experiment could kill string theory, in principle?

Simp - Nothing I could think of. The theory is very strong.

Sal - Seems to me is very weak. A good scientific theory is a theory that can be falsified.

Simp - I am not a philosopher ... ." (Rovelli (2003) 2)

Besonders pikant ist diese Selbstimmunisierungsstrategie insofern, als hier die Unmöglichkeit der Ableitung quantitativer Vorhersagen strategisch eingesetzt wird. Ein Manko der Theorie wird in einen strategischen Vorteil umgemünzt. Für die Physik ist dies zumindest etwas Neues.

\section{Wie konnte es so weit kommen?}

Der Stringansatz existiert nun seit über drei Jahrzehnten, ohne dass es irgendwelche empirischen Bestätigungen oder nur irgendeine quantitative Vorhersage, die als Voraussetzung für eine empirische Kontrolle dienen könnte, gegeben hätte. Und der Stringansatz führt kein Schattendasein, sondern bewegt sich in der Einschätzung aller Beteiligten - deren Zahl nicht gering ist - an der vordersten Front der intensiv vorangetriebenen Bemühungen um eine Theorie der Quantengravitation.

"For nearly 30 years by now a considerable segment of particle physicists deals with a theory that has never witnessed any direct experimental corroboration at all and is unlikely to do so in the foreseeable future." (Dawid (2003) 5)

Inzwischen sind, wenn überhaupt, nur wenige Involvierte noch bereit, ihren Ansatz aufgrund dieser anhaltenden Situation mangelnder empirischer Kontrolle aufzugeben. Vielmehr werden konzeptionelle Überlegungen und metaphysische Voreinstellungen geltend gemacht, die motivieren sollen, wieso die empirische Kontrolle, obgleich sie als wünschenswert erachtet wird, bei ihrem Ausbleiben nicht zu einer Aufgabe des Theorieansatzes führen sollte. Die konzeptionellen Erwägungen haben gegenüber empirischen Belangen die Oberhand gewonnen. Empirisch-wissenschaftliche Vorgehensweisen werden von konzeptionellen, mathematischen Pro- 
zeduren abgelöst, die inzwischen geradezu im Sinne einer mathematisierten Naturmetaphysik ein Eigenleben führen.

Dass es soweit kommen konnte, ist aber nicht dem Stringansatz alleine anzulasten. Vielmehr ist er das konsequente Resultat einer Entwicklung, die im bisher erfolgreichen physikalischen Vereinheitlichungsprogramm fusst. Spätestens mit den Quantenfeldtheorien hat diese Entwicklung nach und nach zu Ausprägungen geführt, für die die empirische Kontrolle eine immer grössere Indirektheit angenommen hat und erst post hoc, nach der Formulierung des theoretischen Ansatzes, zum Einsatz kommt. Im Gegensatz zur Quantenmechanik, die überhaupt erst aufgrund empirischer Befunde, die mit den zuvor etablierten klassischen Theorien nicht in Einklang zu bringen waren, entwickelt wurde, waren es schon für die Quantenfeldtheorien vorrangig konzeptionelle Auslöser, die zu ihrer Entwicklung führten. Oft wurden erst im Nachhinein in grösserem Masze empirische Instanzen zur Kontrolle der Theorien herangezogen. Diese Strategie wurde bei den Quantenfeldtheorien, wenn man einmal von der "Grossen Vereinheitlichten Theorie" und dem Scheitern ihrer Vorhersagen am ausbleibenden Protonenzerfall absieht, fast durchgängig von Erfolg gekrönt. Diese Erfolgsgeschichte der Quantenfeldtheorien hat das Vertrauen in die Methodologie einer vor allem formal-mathematischen, konzeptionellen Fortführung des Vereinheitlichungsgedankens in der Theorienbildung mit anschliessender empirischer Überprüfung geschürt.

"For the last 30 years particle experiment has lost its role to present new and unexplained data to the theoreticians and mostly serves as a mere testing device for existing theoretical schemes. [...] The fact that a theoretical argument has proved capable of determining the course of experimental progress for decades, predicting the discovery of $W$ and $Z$ bosons, new quark types and lepton generations without ever going wrong dramatically increased the trust in pure theorising. The feeling grew that a theory, even if experimentally totally unsupported, can be just too good to be wrong." (Dawid (2003) 12)

Der Stringansatz stellt nun eine konsequente Fortspinnung dieser Vorgehensweise dar und setzt entsprechend auf das durch die Erfolgsgeschichte der Quantenfeldtheorien geschürte Vertrauen in erst einmal ausschliesslich konzeptionelle und theoretische Weiterentwicklungen ohne vorausgehende empirische Auslöser (und ohne sofortige empirische Kontrolle). Nur dass 
hier nun die für die Quantenfeldtheorien im Nachhinein immer auffindbaren empirischen Kontrollinstanzen ausbleiben und vieles dafür spricht, dass es bei diesem Ausbleiben bleiben könnte. - Wer hätte aber etwa den Glashow-Salam-Weinberg-Ansatz zur Beschreibung der elektroschwachen Wechselwirkung einfach so akzeptiert, wenn dieser keine empirisch nachweisbaren Vorhersagen gemacht hätte - vielleicht sogar über Jahrzehnte hinweg?

Für den Stringansatz sah es hinsichtlich seines Status erst einmal so aus, als wäre er den Bedingungen unterworfen, die innerhalb der empirischen Wissenschaften für unbestätigte, spekulative Theorien gelten und die auch innerhalb der Quantenfeldtheorien noch uneingeschränkte Geltung besass. Erst die empirische Bestätigung machte eine tentative theoretische Fortentwicklung im Kontext der Quantenfeldtheorien nach und nach zu einer etablierten Theorie, die Teil eines "Standardmodells" werden konnte. Im Stringansatz wurden aber diese Bedingungen für die Behandlung einer spekulativen Theorie immer irrelevanter: Trotz mangelnder empirischer Bestätigungsinstanzen verlor der Stringansatz in der Einschätzung der immer weiter steigenden Zahl seiner Vertreter weitgehend den Status des nur Spekulativen.

"String theory like many other theories underwent a first phase during which it was considered a mere speculation, before it acquired the status of a well-established research field. Remarkably however, this change of status was not brought about by experimental confirmation but by the solution of some crucial theoretical problems." (Dawid (2004) 2)

Die Grundlage für diesen Wandel in der Einschätzung hinsichtlich des Status des theoretischen Entwurfs lieferten die Eindeutigkeits- und Einzigartigkeitsargumente, die schon relativ früh ins Spiel kamen und schliesslich eine immer stärkere Bedeutung gewannen: ${ }^{242}$

"There is only one possible motivation to accept string theory as a plausible candidate for a description of nature: The principle of underdetermination must be undermined by good arguments that string theory is the only consistent way to build a theory in its regime. [...] The claim that such a revolutionary novel concept still seems to be the 
only choice must be based on even more fundamental physical principles. It is a tedious and tricky task to try to list those principles in detail but they will encompass the principle of least action, basic quantum principles, the principles of special relativity, the existence of a gravitational force and probably a few more. The authority of string theory is inherently based on the claim: If you start from these principles and try to build an overall consistent theory, you will be forced to develop string theory." (Dawid (2003) 15)

Für Richard Dawid, einen der ganz wenigen, die sich von der Seite der Wissenschaftstheorie mit dem Stringansatz und seinen Implikationen beschäftigen, besteht die Konsequenz für die Stringtheorien darin, die Eindeutigkeits- und Einzigartigkeitsargumente als gültigen Ersatz für die ausbleibende empirische Kontrolle anzusehen. Für ihn tritt die Physik mit dem Stringansatz in eine Phase ein, für die andere methodologische Maximen gelten als bisher. Die empirische Kontrolle ist, seiner Auffassung nach, für eine empirisch-wissenschaftliche Theorie nicht mehr notwendigerweise konstitutiv, wenn sich zeigen lässt, dass eine konsequente theoretische Fortspinnung erfolgreicher Theorien zu einer eindeutigen und einzigartigen Konsequenz führt:

"For the first time in history of science it might be justified to see scientific progress pre-eminently and consistently characterised by a new principle, which I want to call the principle of theoretical uniqueness: Fully viable theoretical solutions to complex consistency problems tend to be theoretically unique in the sense that there is no alternative that is equally consistent but would predict different future observational scenarios in the disputed regime." (Dawid (2003) 12)

Die oben ${ }^{243}$ angeführten Argumente für den unausräumbaren Zweifel am deskriptiven Wert empirisch unbestätigter Resultate des physikalischen Vereinheitlichungsprogramms, wenn dieses in ausschliesslich konzeptioneller Fortspinnung bestehender, etablierter theoretischer Konstrukte und in Verkennung der tatsächlichen Gegebenheiten womöglich auf eine Patchwork-Welt, einen irreduziblen Flickenteppich disparater Bereiche, losgelassen wird, lässt diese Einschätzung sehr fraglich erscheinen. Im Falle des Vorliegens einer Patchwork-Welt, das sich mit unseren empi-

243 Siehe das Szenario 2 im Abschnitt "Das Problem der empirischen Kontrolle" des vorliegenden Teilkapitels. 
risch-wissenschaftlichen Mitteln nie ausschliessen lassen wird, lassen sich theoretische Konstrukte, die im Vereinheitlichungsprogramm motiviert erscheinen, zwar vielleicht im Sinne einer mathematisch-modelltheoretischen Extrapolation formulieren, aber sie müssen nicht notwendigerweise etwas mit der Wirklichkeit zu tun haben. Eine empirische Stützung könnte diese Gefahr allerdings relativieren.

Auch wenn die Eindeutigkeit und Einzigartigkeit des Stringansatzes (oder irgendeines anderen theoretischen Entwurfs) auf irgendeine Weise nachgewiesen werden könnte, müsste man diesen also dennoch zumindest solange nur als konzeptionelles Konstrukt ansehen, bis er empirische Belege aufweist. Kann er dies nicht, bleibt er nichts mehr als dieses Konstrukt, dem nicht ohne weiteres deskriptive Eigenschaften zugeschrieben werden können. - Aber inzwischen haben sich die Eindeutigkeits- und Einzigartigkeitsargumente ohnehin als unhaltbar erwiesen, und dies nicht etwa aufgrund von Überlegungen, die an den Stringansatz von aussen herangetragen worden wären, sondern vielmehr aufgrund von innertheoretischen Entwicklungen. ${ }^{244}$ Diese Entwicklungen lassen es darüberhinaus als höchst fraglich erscheinen, dass es jemals eine direkte empirische Bestätigung für den Stringansatz geben wird. ${ }^{245}$

\footnotetext{
$244 \quad$ Siehe Kap. 5.

Siehe Kap. 5.3.
} 


\subsection{Problemtypologie}

\section{Zwei Arten von Problemen}

Die Probleme, die theoretische Neuentwicklungen im Rahmen der empirischen Wissenschaften zu lösen bzw. mit denen sie sich zu beschäftigen haben, lassen sich in grundsätzlichster Weise in zwei Gruppen einteilen:

Externe Probleme: Empirisch-wissenschaftliche Problemstellungen, zu deren Lösung eine Theorie entwickelt wurde oder deren in Aussicht gestellte Lösung eine Theorie überhaupt erst interessant machen.

Interne Probleme: Konzeptionelle und mathematisch-modelltheoretische Probleme, die überhaupt erst bei der Entwicklung einer Theorie auftreten und nun von dieser zu lösen sind.

Diese Unterscheidung lässt, wie im Folgenden gezeigt werden soll, ein wesentlich deutlicheres Licht auf den Status fallen, den der Stringansatz zur Zeit für sich beanspruchen kann.

\section{Externe Probleme}

Es gibt, wie bei der Erörterung seiner Entwicklung deutlich geworden sein dürfte, keine externen Probleme, zu deren Lösung der Stringansatz überhaupt erst entwickelt worden wäre. ${ }^{246}$ Es gibt für den Stringansatz jedoch in der Weise externe Probleme, als die Inaussichtstellung ihrer Lösung den Stringansatz als physikalische Theorie interessant machen. Indem der Stringansatz die erfolgreiche und empirisch adäquate Einbeziehung der Gravitation in eine vereinheitlichte Quantentheorie aller Wechselwirkungen verspricht, ist er, wenn er auch ursprünglich nicht zu diesem Zweck

\footnotetext{
246

Siehe Kap. 4.1.
} 
entwickelt wurde, als Theorieansatz relevant geworden. In dieser Hinsicht lässt sich das Problem einer nomologischen Vereinigung aller Wechselwirkungen unter Einschluss der Gravitation und mithin die Etablierung einer Theorie der Quantengravitation unter der Randbedingung der Reproduktion der bestehenden Phänomenologie als das entscheidende externe Problem ansehen, das der Stringansatz zu lösen vorgibt. Dass der Stringansatz eine Lösung dieses externen Problems in Aussicht stellt, ist die primäre Motivation für seine Weiterentwicklung. ${ }^{247}$

\section{Legitime Erklärungsansprüche an eine fundamentale Theorie}

Mit dieser primären externen Motivation gehen weitere Erklärungsdesiderate einher, die an einen Ansatz herangetragen werden müssen, der sich anschickt, als fundamentale physikalische Theorie aller Wechselwirkungen aufzutreten. Diese Erklärungsdesiderate gehören insofern ebenso in den Kontext der externen Problemstellungen, die der Stringansatz zu lösen hat, wenn er als fundamentale Theorie erfolgreich sein will.

So sollte eine fundamentale, vereinheitlichte Theorie aller Wechselwirkungen einschliesslich der Gravitation ohne freie Parameter auskommen, da die Erklärung dieser freien Parameter ansonsten anschliessend im Rahmen einer fundamentaleren Theorie anzustreben wäre - was wiederum hiesse, dass die vorliegende vereinheitlichte Theorie nicht die fundamentale Theorie sein kann, die man gerade erreicht zu haben vermutete. Oder die fundamentale Theorie müsste verdeutlichen, wieso die auch in ihrem Kontext immer noch vorliegenden freien Parameter als grundlegend kontingent angesehen werden müssen, also in den Kontext einer mit theoretischen Mitteln nicht erklärbaren irreduziblen Kontingenz gehören. Der Stringansatz als angehende fundamentale Theorie sollte also entweder das Zustandekommen der Parameter des Standardmodells der Quantenfeldtheorien erklären können; oder er müsste verdeutlichen, wieso diese Parameter einer grundlegenden Kontingenz entsprechen und insofern nicht weiter erklärt werden können.

$247 \quad$ Siehe vor allem Kap. 4.2. 
"A really fundamental theory should have such a rigid structure that all phenomena in the low-energy regime, such as particle masses or coupling constants, can be predicted in an unique way." (Kiefer (2004) 20)

Jedoch sollte der Stringansatz, wenn er den Status einer fundamentalen Theorie für sich geltend macht, nicht nur diese Parameter in ihrem Zustandekommen erklärbar werden lassen. Er sollte vielmehr in möglichst umfassender Weise die offenen Probleme des Standardmodells lösen. Hierzu zählen insbesondere die Fragen, wie es zur Festlegung hinsichtlich der Eichinvarianzen bzw. Symmetrien des Standardmodells kommt, wie und warum bestimmte Symmetriebrechungsmechanismen in unserer Welt realisiert sind, wie sich die Zahl der beobachtbaren Teilchengenerationen erklären lässt, wieso Materieteilchen chiral sein können - und vielleicht auch, warum quantenfeldtheoretische Berechnungen $\mathrm{zu}$ vollkommen falschen Werten hinsichtlich der kosmologischen Konstante führen, wenn diese mit der Energiedichte des quantenfeldtheoretischen Vakuums identifiziert wird. - Bisher zeichnet sich jedoch für diese offenen Fragen des Standardmodells im Stringansatz nur in den wenigstens Fällen eine Lösung ab; und dann auch meist keine eindeutige Lösung.

"Sal - [...] There are other open problems of the standard model [...]. Like understanding why there are three families. Does string theory solve that?

Simp - ... no ...

Sal - why the cosmological constant is small?

Simp - ... no ...

Sal - giving a better account of symmetry breaking?

Simp - ... no ... ." (Rovelli (2003) 4)

Immerhin erklärt der Stringansatz, im Gegensatz zu allen Vorgängertheorien, grundsätzlich das Zustandekommen der Zahl der Teilchengenerationen. Diese Zahl wird in den Stringtheorien durch die Topologie der kompakten Raumdimensionen determiniert, die sich dynamisch in der Struktur der zulässigen Oszillationsspektren des String niederschlägt. Die Zahl der Teilchengenerationen ist gleich dem halben Absolutbetrag der Euler-Zahl des kompakten Raumes. ${ }^{248}$ Dennoch führt der Stringansatz damit noch nicht zu einer Vorhersage hinsichtlich der Zahl der Teilchengenerationen,

248 Siehe Kaku (1999), Kap. 10.6. 
weil die Topologie der kompakten Raumdimensionen völlig unklar bleibt und es eine Vielzahl von Varianten gibt, die offensichtlich zu Generationszahlen zwischen drei und 480 führen. Für die meisten Kompaktifizierungsszenarien im Stringansatz - und vor allem für alle explizit formulierten Modelle - zeichnen sich Generationszahlen ab, die deutlich grösser als drei sind. Generationszahlen über drei scheinen jedoch, wenn man den Berechnungen der Quantenfeldtheorien vertraut, nicht mit der beobachtbaren Phänomenologie und ihren Konsequenzen verträglich zu sein.

Das Problem der Teilchengenerationszahl scheint in fundamentaler Weise an das noch explizit zu erörternde Kontingenz- und Selektionsproblem des Stringansatzes gekoppelt zu sein, zu dem es aufgrund der Vielzahl der möglichen Stringszenarien kommt. ${ }^{249}$ Dies trifft jedoch ebenso auf die Festlegung der Eichinvarianzen und der Parameter des Standardmodells, auf die Frage nach dem Zustandekommen einer gebrochenen Supersymmetrie sowie auf das Problem der Vorhersage der Energiedichte des Vakuums bzw. der kosmologischen Konstante zu. Aufgrund seiner zentralen Stellung innerhalb der Problemlandschaft des Stringansatzes, seiner relativ komplexen Argumentationslage und den mit dieser einhergehenden philosophischen Implikationen und Alternativen wird das Kontingenzproblem separat in allen seinen Ausprägungen und Konsequenzen im folgenden Kapitel zu behandeln sein. ${ }^{250}$

Neben der Erklärung der offenen Fragen des Standardmodells der Quantenfeldtheorien, die fast durchgängig in den Sog des Kontingenzproblems geraten, gehören zu den von einer fundamentalen Theorie zu erwartenden Erklärungsleistungen einige weitere grundsätzliche Fragestellungen, die in den Kontext der externen Problemstellungen des Stringansatzes gehören. $\mathrm{Zu}$ diesen zählen nicht zuletzt etwa die von einer Theorie der Quantengravitation - und damit der "Quantengeometrie" - zu erwartenden Lösungen auf die Fragen, was überhaupt die Natur von Raum und Zeit ausmacht, was über die Dimensionalität der (unkompakten) Raumzeit entscheidet ${ }^{251}$ und

\footnotetext{
249

Siehe Kap. 5.3.

$250 \quad$ Siehe Kap. 5.

251 Die Frage der Dimensionalität der Raumzeit lässt sich gleichermassen als internes Problem des Stringansatzes und seiner Kompaktifizierungs- und Branweltmodelle ansehen - wie als externes Problem, welches von einer fundamentalen Theorie zu lösen wäre, wenn man die Phänomenologie der 3+1er-Raumzeit nicht einfach als Faktum hinnehmen will.
} 
wie Masse als entscheidende gravitative und damit geometrisierende Grösse zustandekommt.

Die Äquivalenz von träger und schwerer Masse ist eine der Grundlagen der Allgemeinen Relativitätstheorie. Sie wird von dieser als letztlich empirisch stützbarer Befund vorausgesetzt und spielt eine zentrale Rolle bei der Festlegung der Theoriestruktur. Die Allgemeine Relativitätstheorie erklärt jedoch diese Äquivalenz nicht, sondern nimmt sie eben als Gegebenheit hin. Von einer fundamentalen Theorie sollte man sich daher eine Erklärung dafür erhoffen, wieso die träge Masse als Bewegungsgrösse mit der schweren Masse als gravitativer "Ladung" gleichzusetzen ist. Im Gegensatz etwa zur elektrischen Ladung, die, abhängig von ihrem Wert, jeweils zu unterschiedlichen dynamischen Entwicklungen - im klassischen Bild: unterschiedlichen Trajektorien - führt, folgen Objekte mit beliebiger Masse gemäss der Allgemeinen Relativitätstheorie identischen Trajektorien: Geodäten. Gerade dies hat zur Folge, dass sich die Gravitation im Gegensatz zum Elektromagnetismus geometrisieren lässt. Zudem führt die speziellrelativistische Äquivalenz von Masse und Energie zur Kopplung der Gravitation mit allen anderen Wechselwirkungskräften. Die anderen Wechselwirkungen sind untereinander nicht auf diese Weise verbunden. Die Gravitation steht aufgrund ihrer Wechselwirkungsstruktur und ihrer Identität mit der Metrik der Raumzeit in einem asymmetrischen Verhältnis zu den anderen Wechselwirkungen. (Dies zeigt sich nicht zuletzt auch in den Schwierigkeiten einer gleichartigen quantenfeldtheoretischen Behandlung aller Wechselwirkungen einschliesslich der Gravitation. ${ }^{252}$ ) Von einer fundamentalen Theorie sollte man sich nun aber nicht nur die Reproduktion dieser dynamischen Asymmetrie zwischen der Masse und den Feldladungen aller anderen Wechselwirkungen erhoffen, sondern vielmehr eine Erklärung, wie diese Asymmetrie zwischen der Gravitation und den anderen Wechselwirkungen zustandekommt und was Masse letztendlich ist. Es gibt bisher weder im Stringansatz, noch im Rahmen irgendeiner konkurrierenden Theorie eine angemessene Antwort auf diese Frage. Die Masse eines "Teilchens" entspricht im Stringansatz der Energie der entsprechenden Stringoszillation. Dies erklärt zwar grundsätzlich die Determinierung bestimmter Massewerte, wenn man vom bisher ungelösten Problem der Ableitung quantitativer Ergebnisse einmal absieht. Aber es erklärt nicht, was Masse ist. Der Stringansatz geht in dieser Hinsicht letztlich nicht weiter als das Standardmodell der Quantenfeldtheorien, in dem das Zustandekommen

$252 \quad$ Siehe vor allem Kap. 1. und 3. 
von Masse über den Higgs-Mechanismus und die spontane Symmetriebrechung erklärt werden soll.

Das noch weitaus komplexere Problem der Raumzeit wird - aus ähnlichen Gründen wie sie schon für das Kontingenzproblem geltend gemacht wurden - separat im übernächsten Kapitel zu behandeln sein. Die damit verbundenen Detailprobleme und Konsequenzen sind einfach zu vielgestaltig und differenziert, um sie pauschal im Rahmen einer Typologisierung der Problemlandschaft des Stringansatzes abzuhandeln.

\title{
Interne Probleme
}

Trotz der vielfältigen externen Problemstellungen, mit denen sich der Stringansatz auseinandersetzen müsste, spielten die internen Probleme im Entwicklungsgang des Stringansatzes die dominante Rolle. Die Entwicklung war durchgängig und in geradezu selbstbezüglicher Weise bestimmt von theoretischen und konzeptionellen Problemen, die überhaupt erst im Rahmen dieser Entwicklung aufgetreten sind. ${ }^{253}$

\begin{abstract}
"Sal - [...] the different ingredients of the theory are not solutions of problems of the standard model, or solutions of problems we have in understanding of the world: they are solutions to problems raised by other ingredients of the same theory. According to the Catholic doctrine there are two miracles happening in a Mass: the first miracle is that wine becomes truly blood. The second miracle is that the blood looks and smells like wine... it is just a miracle added to patch up the inconsistency created by the first ... ." (Rovelli (2003) 6)
\end{abstract}

Der Stringansatz ist viel stärker mit sich selbst als mit der Lösung externer Problemstellungen beschäftigt. Allerdings hat er dabei noch nicht den Erfolgsstatus der katholischen Messe erreicht. Lange Zeit herrschte zwar die Auffassung oder zumindest Hoffnung vor, dass sich die internen Probleme

$253 \mathrm{Zu}$ diesen internen Problemen zählt nicht zuletzt auch das in Kap. 4.3. erörterte Problem der empirischen Kontrolle. Externe Probleme mit der Empirie lägen nur vor, wenn es, was nicht der Fall ist, für den Bereich der Quantengravitation empirische Daten gäbe, die von einer entsprechenden Theorie zu reproduzieren wären. 
im Rahmen eines eindeutigen, konsistenten Lösungsansatzes gleichsam auf einen Schlag lösen lassen. ${ }^{254}$ Diese Hoffnungen haben sich jedoch, wie noch zu erörtern sein wird, schliesslich zerschlagen. ${ }^{255}$ Die Behandlung der internen Probleme stellt noch immer das primäre Betätigungsfeld der Stringtheoretiker dar.

\section{Fehlende fundamentale Prinzipien}

Das zentrale interne Problem des Stringansatzes betrifft die fundamentalen Prinzipien. Wie im Rahmen der Erörterung ihrer Entstehungsgeschichte schon verdeutlicht, ${ }^{256}$ verfügen die Stringtheorien über kein fundamentales physikalisches Prinzip, aus dem sich die Dynamik und ihre nomologische Grundlage ableiten liesse.

"[...] the central defining principle of string theory is not known." (Polchinski (1996) 9)

Es liegen ausschliesslich perturbative Formulierungen vor.

"A key difficulty in string theory is the lack of a complete nonperturbative formulation." (Rovelli (1998) 4)

Die Suche nach einer nicht-perturbativen Formulierung der Theorie hat, trotz intensiver Bemühungen, bisher zu keinem Resultat geführt.

"All that exists at the moment is a divergent series that is conjectured to be an asymptotic perturbation series for some as yet undefined nonperturbative string theory." (Woit (2001) 1) 257

\footnotetext{
$254 \quad$ Siehe Kap. 5.1.

255 Wiederum sei hier auf das Kontingenzproblem verwiesen. Siehe Kap. 5.2.

256 Siehe vor allem Kap. 4.1.

257 Gegenüber der Einschätzung des Mathematikers und entschiedenen Stringkritikers Peter Woit, der zur Zeit an einem Buch mit dem Titel Not Even Wrong - The Failure of String Theory and the Continuing Challenge to Unify the Laws of Physics schreibt, ist die (allerdings kurz nach dem Aufwind der Zweiten Superstring-Revolution verfasste) Kommentierung von Carlo Rovelli, einem der Begründer der Loop Quantum Gravity, erstaunlich moderat:
} 
Und es ist nicht zuletzt ${ }^{258}$ die Anwendung fast ausschliesslich perturbativer Prozeduren, die quantitative Vorhersagen im Stringansatz bisher verhindert hat und damit zum Problem der empirischen Kontrolle führt. ${ }^{259}$

Sogar manche Stringtheoretiker hegen inzwischen Zweifel, ob jemals ein fundamentales Prinzip gefunden werden wird, aus dem sich die Stringdynamik ableiten liesse.

"At the moment it [...] seems very hard to go beyond this point and derive the numerical details of the standard model from first principles; perhaps it will never be possible, because there might simply be no such first principles." (Lerche (2000) 12)

Jedenfalls sind das fehlende fundamentale Prinzip der Stringtheorien und ihre nahezu ausschliessliche Verwendung perturbativer Vorgehensweisen die Ursache dafür, dass sich der Stringansatz weitgehend im Bereich tentativer Mathematik bewegt. ${ }^{260}$

"Thus the research program called 'string theory' can be taken to be a set of activities in search of the definition of a theory to be called 'STRING THEORY'. What exists so far is only a collection of results concerning many different 'string theories'. These are conjectured to be each an approximate description of some sector of the so far undefined STRING THEORY." (Smolin (2003) 32f)

Diese tentative Mathematik kennzeichnet die gesamte bisherige Entwicklungsgeschichte des Stringansatzes und deren zum Teil bizarren Charak-

"String theory presently exists at two levels. First there is a well developed set of techniques that define the string perturbation expansion over a given metric background. Second, the understanding of the nonperturbative aspects of the theory has much increased in recent years and in the string community there is a widespread faith, supported by numerous indications, in the existence of a yet-tobe-found full non-perturbative theory, capable of generating the perturbation expansion." (Rovelli (1998) 4)

Siehe für eine frühe Kritik am Stringansatz auch Ginsparg / Glashow (1986).

258 Neben dem noch zu besprechenden Kontingenzproblem: Siehe Kap. 5.

259 Siehe Kap. 4.3.

260 Siehe Kap. 4.1. 
ter. ${ }^{261}$ Es gibt trotz der Entdeckung der Dualitätsbeziehungen keine wirkliche physikalische Theorie, schon gar keine fundamentale Theorie, sondern eher eine lange Liste von paradigmatischen Lösungsansätzen und tentativen Ad-hoc-Prozeduren, die bisher in den meisten Fällen die in sie gesetzten Erwartungen nicht erfüllt haben. Das inhomogene Konvolut namens Stringtheorie kennzeichnet sich immer noch durch eine erhebliche Beliebigkeit.

"Of course we have no nonperturbative definition of string theory and anything can happen." (Polchinski (2000a) 180)

Ohne fundamentales physikalisches Prinzip ist der Rahmen für Spekulationsmöglichkeiten im Stringansatz weit gefasst:

"Is string theory itself an inevitable consequence of some broader principle - possibly but not necessarily a symmetry principle - in much the same way that the equivalence principle inexorably leads to general relativity or that gauge symmetries lead to the nongravitational forces? As of this writing, no one has any insight into the answer to this question. To appreciate its importance, we need only imagine Einstein trying to formulate general relativity without having had the happy thought he experienced in the Bern patent office in 1907 that led him to the principle of equivalence. It would not have been impossible to formulate general relativity without first having this key insight, but it certainly would have been extremely difficult." (Greene (1999) 375)

\section{Interne Aufräumarbeiten}

Die meisten der weiteren internen Probleme des Stringansatzes manifestieren sich in den vielfältigen innertheoretischen Aufräumarbeiten: Hierbei geht es vor allem um die Suche nach angemessenen Verfahrensweisen beim Auftreten von Inkonsistenzen, Anomalien und Besonderheiten bei der Theorienbildung und um Strategien des Umgangs mit Konsequenzen

$261 \quad$ Siehe Kap. 4.1. 
der Theorienbildung, die erst einmal nicht mit der Phänomenologie in Einklang stehen.

So führte die Erfordernis der Einbeziehung von Fermionen und Chiralität in den Stringansatz zur konzeptionell erfolgreichen Implementierung der Supersymmetrie. ${ }^{262}$ Diese wirft jedoch wiederum Folgeprobleme auf: Die Supersymmetrie ist, wie uns die Empirie zeigt, notwendigerweise gebrochen, denn die zu erwartenden supersymmetrischen Partner zu den bekannten Materieteilchen und Wechselwirkungsquanten haben ganz sicher nicht die gleiche Masse bzw. Energie wie diese, sonst hätten wir sie längst gefunden. Zudem hängt die Supersymmetrie mit dem Problem der kosmologischen Konstante zusammen und bietet damit ein Beispiel für die unmittelbaren kosmologischen Implikationen des Stringansatzes: Eine ungebrochene Supersymmetrie führt, wie sich zeigen lässt, notwendigerweise immer zu einer verschwindenden kosmologischen Konstante. ${ }^{263}$ Eine verschwindende kosmologische Konstante ist jedoch mit den heutigen astrophysikalischen Daten nicht vereinbar. Eine gebrochene Supersymmetrie führt aber zu nicht unerheblichen Problemen im Stringansatz. Wie lässt sich also die Erfordernis der Supersymmetrie im Stringansatz damit vereinbaren, dass diese, wie die Phänomenologie zeigt, offensichtlich gebrochen sein muss? - Die Supersymmetriebrechung könnte eine Folge der Kompaktifizierung sein. Auf der flachen zehndimensionalen Raumzeit der perturbativen Stringtheorien gilt die Supersymmetrie notwendigerweise. Dass sie für unsere Vierer-Raumzeit offensichtlich gebrochen ist und wir keine Supersymmetrie-Multipletts beobachten, sollte sich aus dem Kompaktifizierungsszenarien in irgendeiner Weise ergeben. Die genauen Umstände sind jedoch bisher noch völlig unklar.

"So far, no convincing method has been proposed to yield supersymmetry breaking." (Kaku (1999) 543)

Das ändert sich auch nicht mit den Ergebnissen aus den zaghaften Vorstössen in den nicht-perturbativen Bereich der Stringtheorien.

262 Ebenso führte die Vermeidung von Tachyonen-Zuständen in den frühen Stringtheorien zur sogenannten GSO-Projektion, die ihre Rechtfertigung wiederum post hoc im Kontext der Einbeziehung der Supersymmetrie erhielt. Siehe Kap. 4.1.

263 Siehe Kap. 5.2. und 5.3. 
"M-theory still cannot explain why supersymmetry is broken, or give us insight into the cosmological constant." (Kaku (1999) 543)

In der Idee, dass die Brechung der Supersymmetrie mit der Kompaktifizierung zu tun haben könnte, manifestiert sich die Kopplung des Problems der gebrochenen Supersymmetrie mit einem weiteren zentralen Problemkomplex des Stringansatzes, der - auch schon völlig unabhängig von dieser Kopplung - zu umfänglichen Aufräumarbeiten Anlass gibt. Es handelt sich um die möglichen Konsequenzen, die sich aus der innertheoretischen Festlegung der Dimensionalität der Raumzeit im Stringansatz ergeben:

Die Anforderung der Vermeidung von Anomalien bzw. der Berücksichtigung der Lorentz-Invarianz und der Unitarität hat zur Folge, dass die perturbativen Superstringtheorien nur auf zehn Raumzeitdimensionen konsistent formulierbar sind. Formal geht diese Anforderungsstruktur in die Super-Virasoro-Algebra der Fourierentwicklung des perturbativen Ansatzes ein. ${ }^{264}$ Für einen Ansatz, der vier Wechselwirkungen einheitlich beschreiben soll, ist dies grundsätzlich nicht so abwegig - vor allem nach der Erfahrung mit der Kaluza-Klein-Theorie, die mittels einer fünften Dimension versuchte, den klassischen Elektromagnetismus dynamisch in die Allgemeine Relativitätstheorie einzubeziehen. ${ }^{265}$

"[...] the main idea of Kaluza-Klein theories is to represent gauge invariance in four-dimensional space-time as resulting from the group of isometries of an internal n-dimensional manifold, a beautiful geometrical idea." (Alvarez-Gaumé / Vázquez-Mozo (1992) 10)

Der Stringansatz ist die erste Theorie, die eine Festlegung hinsichtlich der Dimensionalität der Raumzeit zwingend macht - und diese nicht etwa, wie die Kaluza-Klein-Theorien, ad hoc einführt.

"String theory is actually a natural setting not only for gravitation and gauge fields but also for the Kaluza-Klein mechanism. [...] in contrast to field theory, string theory points to the existence of extra dimensions and even specifies their number." (O'Raifeartaigh / Straumann (2000) 15) 
Die Frage der Dimensionszahl der Raumzeit ist damit im Stringansatz zwar innertheoretisch gelöst, die Dimensionszahl und ihr Zustandekommen bleibt aber letztlich physikalisch unverstanden.

"[...] why does string theory require the particular number of nine space dimensions to avoid nonsensical probability values? This is probably the hardest question in string theory to answer without appealing to mathematical formalism. A straightforward string theory calculation reveals this answer, but no one has an intuitive, nontechnical explanation for the particular number that emerges. The physicist Ernest Rutherford once said, in essence, that if you can't explain a result in simple, nontechnical terms, then you don't really understand it." (Greene (1999) 203)

Vor allem aber: Auch wenn die Stringtheorien notwendigerweise mit zehn Dimensionen arbeiten, so hat unsere phänomenologische Raumzeit offensichtlich nur vier Dimensionen. Was tun? Wie kommen wir von den zehn Dimensionen des Stringansatzes zu unserer phänomenologischen ViererRaumzeit? - Es gibt, wie zuvor schon erläutert, zwei Erklärungsszenarien: zum einen die Kompaktifizierung der überzähligen Dimensionen, ${ }^{266}$ zum anderen die Anbindung der Materie und Felder an Dirichlet-Branen, ${ }^{267}$ vielleicht aber auch eine Kombination beider Möglichkeiten. ${ }^{268}$

Hinsichtlich der ersten Variante stellt sich erst einmal die Frage, in welcher Form die Kompaktifizierung der überzähligen Dimensionen erfolgen könnte. Dieses Problem ist im Rahmen des Stringansatzes zwar nicht dynamisch verstanden, ${ }^{269}$ aber zumindest konzeptionell grundsätzlich gelöst. Für eine Kompaktifizierung kommt im Rahmen der perturbativen Stringtheorien nur eine komplexe Mannigfaltigkeit mit angemessener Holonomie-Gruppe und Metrik in Frage. Die entsprechenden Bedingungen sind

\footnotetext{
266 Siehe Kap. 2.2.

267 Siehe Kap. 2.4.

268 Siehe Kap. 2.4.
}

269 "The problem, however, is that dimensional breaking from a 10-dimensional theory down to four dimensions can occur only nonperturbatively. To any finite order in the perturbation theory, the dimension of space-time seems perfectly stable. [...] Unfortunately, we do not yet understand how to perform realistic nonperturbative calculations in string theory [...]. Thus, physicists have not been able to calculate the stability of any classical vacuum solution." (Kaku (1999) 337) 
gerade für sechsdimensionale Calabi-Yau-Räume gegeben. ${ }^{270}$ - Interessanter ist das Problem der physikalischen Konsequenzen einer solchen Kompaktifizierung. Denn der jeweilige Kompaktifizierungsmodus bestimmt die Niederenergiephysik im vierdimensionalen Raum:

"According to string theory, the universe is made up of tiny strings whose resonant patterns of vibration are the microscopic origin of particle masses and force charges. String theory also requires extra space dimensions that must be curled up to a very small size to be consistent with our never having seen them. But a tiny string can probe a tiny space. As a string moves about, oscillating as it travels, the geometrical form of the extra dimensions plays a critical role in determining resonant patterns of vibration. Because the patterns of string vibrations appear to us as the masses and charges of the elementary particles, we conclude that these fundamental properties of the universe are determined, in large measure, by the geometrical size and shape of the extra dimensions. That's one of the most far-reaching insights of string theory." (Greene (1999) 206)

Die geometrischen und topologischen Symmetrien des kompakten sechsdimensionalen Raumes erscheinen als Eichfelder einer effektiven Theorie auf der verbleibenden ausgedehnten Vierer-Raumzeit. Die Erhaltungsgrössen innerhalb des kompakten Raumes treten als "Ladungen" in der nicht-kompakten Vierer-Raumzeit in Erscheinung. Die starke, die schwache und die elektromagnetische Wechselwirkung sollten sich als Konsequenz des jeweiligen Kompaktifizierungsmodus ergeben. Damit kommt das Kompaktifizierungsszenario des Stringansatzes dem Geometrisierungsprogramm von Einstein, Kaluza, Klein und Wheeler schon sehr nahe. In gewisser Weise bietet gerade die Kompaktifizierung eine Grundlage für die Geometrisierung aller Wechselwirkungen entsprechend der Geometrisierung der Gravitation innerhalb der Allgemeine Relativitätstheorie.

Leider ergibt sich jedoch keine eindeutige Lösung für die Kompaktifizierung. Es gibt sehr viele Möglichkeiten für die Kompaktifizierungsmodi innerhalb der Stringtheorien. Und diese Vielzahl der möglichen Kompaktifizierungsmodi tritt innerhalb der Vierer-Raumzeit physikalisch sehr unterschiedlich in Erscheinung. Der Stringansatz legt kein eindeutiges physikalisches Ergebnis nahe, sondern vielmehr eine Vielzahl physikalisch unter-

$270 \quad$ Siehe Kap. 2.2. 
schiedlicher Möglichkeiten. Neuere Abschätzungen gehen von $10^{100}$ bis $10^{500}$ möglichen Szenarien mit jeweils unterschiedlichen Niederenergieimplikationen innerhalb des perturbativen Stringansatzes aus. Der Kompaktifizierungsansatz zur Lösung des Problems der überzähligen Dimensionen mündet also unmittelbar im Kontingenzproblem. ${ }^{271}$

Unabhängig von dieser Problematik kann man sich natürlich fragen, wieso eine Kompaktifizierung gerade von zehn $\mathrm{zu}$ vier Raumzeitdimensionen führt.

"[...] if the equations of string theory [...] show that the universe has nine space dimensions and one time dimension, why is it that the three space (and one time) dimensions are large and extended while all the others are tiny and curled up? Why aren't they all extended, or all curled up, or some other possibility in between? At present no one knows the answer to this question." (Greene (1999) 204)

Tentative Versuche, die Kompaktifizierung dynamisch zu erfassen, also die dynamische Entwicklung einer Raumzeit mit anfänglich zehn gleichwertigen Dimensionen und den entsprechenden Stringzuständen zu berechnen, um vielleicht nachweisen zu können, wie es gerade zu einer vierdimensionalen phänomenologischen Raumzeit kommt, haben gezeigt, dass sich im Rahmen der Kompaktifizierung bzw. Dekompaktifizierung beliebige Dimensionalitäten ergeben können, ohne jegliche statistische Signifikanz für eine vierdimensionale Raumzeit. ${ }^{272}$ Auch hier schimmert das Kontingenzproblem wieder auf.

"At present, our arsenal of techniques is still to primitive to answer the question of whether the theory undergoes spontaneous dimensional breaking." (Kaku (1999) 404)

Muss der Stringansatz jedoch überhaupt eine Kompaktifizierung der über unsere phänomenologische Vierer-Raumzeit hinausgehenden Dimensionen als Gegebenheit annehmen? Vielleicht kann man von einer ausgedehnten, unkompakten Zehner-Raumzeit ausgehen und auf andere Weise erklären, wieso es zur phänomenologischen Vierer-Raumzeit kommt. Vielleicht gibt

\footnotetext{
$271 \quad$ Siehe Kap. 5.

272 Siehe Easther / Greene / Jackson / Kabat (2005).
} 
es überhaupt keine Kompaktifizierung. Warum nehmen wir aber dann nur vier Raumzeitdimensionen wahr? Eine mögliche Antwort auf diese Frage und damit eine alternative Lösung zum Problem der Diskrepanz zwischen den zehn Dimensionen der perturbativen Superstringtheorien und den vier Dimensionen unserer phänomenologischen Raumzeit liefern gerade die Branwelt-Szenarien. ${ }^{273}$ Diese gehen von einer Anbindung der Materie und Felder an Dirichlet-Branen aus. Dass wir nur vier Raumzeitdimensionen wahrnehmen, könnte daran liegen, dass die kosmische Materie an eine dreidimensionale Dirichlet-Bran gebunden ist. Vielleicht ist unser Universum also eine (sich zeitlich entwickelnde) D3-Bran in einer zehndimensionalen Raumzeit. Es könnte innerhalb der Raumzeit noch andere solche Branen geben. - Aber auch wenn die Branweltszenarien eine interessante Idee in den Stringansatz einbringen, so ist diese bisher bestenfalls Spekulation. Dies gilt gleichermassen für die diversen Kompaktifizierungsszenarien und erst recht für Szenarien, die eine Kombination beider Möglichkeiten vorsehen. ${ }^{274}$ Es ist letztendlich nicht einmal auszuschliessen, dass die vom Stringansatz postulierte Dimensionalität der Raumzeit ein Artefakt ist, welches auf einer unangemessenen modelltheoretischen Grundlage im Stringansatz beruht. Dann wären alle Aufräumarbeiten und die ingeniösen Ideen in ihrem Kontext müssig.

Damit ist es nun höchste Zeit für eine Beschäftigung mit den beiden besonders virulenten Problemzonen des Stringansatzes, die schon im Vorausgehenden immer wieder aufschimmerten und heute zu seinen zentralen konzeptionellen Baustellen zählen. Dies ist zum einen das im folgenden Kapitel zu erörternde Kontingenz- und Selektionsproblem, zum anderen das im übernächsten Kapitel zu behandelnde Problem der (Hintergrund-) Raumzeit.

Das Problem der Raumzeit ist ein originär externes Problem, das seinen Ausgang darin nimmt, dass der Stringansatz eine der grundsätzlicheren Anforderungen an eine Quantengravitationstheorie nicht einlöst: nämlich nicht ohne guten Grund hinter die empirisch untermauerten, fundamentaleren Einsichten der Allgemeinen Relativitätstheorie hinsichtlich unseres Verständnisses von Raum und Zeit zurückzufallen, sondern sich vielmehr, vielleich auf diesen Einsichten aufbauend, um eine weitergehende Klärung der Frage nach der Natur von Raum und Zeit zu bemühen. Was jedoch als

273 Siehe Kap. 2.4.

274 Siehe Kap. 2.4. sowie Aspinwall (2004). 
externes Problem startet, führt mit seinen Lösungsansätzen und Konsequenzen sehr schnell zu diversen internen Problemabkopplungen, die teilweise ein Eigenleben annehmen.

Das Kontingenz- und Selektionsproblem hingegen startet als internes Problem und wächst dann mit seinen Konsequenzen schliesslich in eine externe Problemlandschaft hinein, in der es nicht zuletzt um die Fragen geht, welches Mass an Kontingenz eine fundamentale Theorie verträgt, wie sich nomologische Möglichkeiten zur faktischen Realität verhalten, welche Selektionsmechanismen vom Möglichen zum Faktischen führen könnten, ob angesichts der Beschaffenheit unserer Welt ("Feinabstimmung") der angemessene Weg zur Erklärung kontingenter Faktizität und Phänomenologie wenn man nicht auf unerklärliche kosmische Koinzidenzen oder gar auf die Idee eines absichtlich geschaffenen Designer-Universums zurückgreifen möchte - vielleicht im anthropischen Prinzip zu suchen wäre und was dies schliesslich für die Physik als (ursprünglich) empirische Wissenschaft bedeutet. 